\title{
A comparative and diachronic analysis of film title translations and appellative effect transfer into Croatian and German
}

Gabrić, Petar; Brajković, Iva; Licchetta, Letizia; Bezuh, Juraj; Kelčec Ključarić, Dorotea

Source / Izvornik: Hieronymus: Journal of Translation Studies and Terminology, 2017, 4, 1 27

Journal article, Published version

Rad u časopisu, Objavljena verzija rada (izdavačev PDF)

Permanent link / Trajna poveznica: https://urn.nsk.hr/urn:nbn:hr:131:828954

Rights / Prava: Attribution-NonCommercial-NoDerivatives 4.0 International/ImenovanjeNekomercijalno-Bez prerada 4.0 međunarodna

Download date / Datum preuzimanja: 2023-04-26

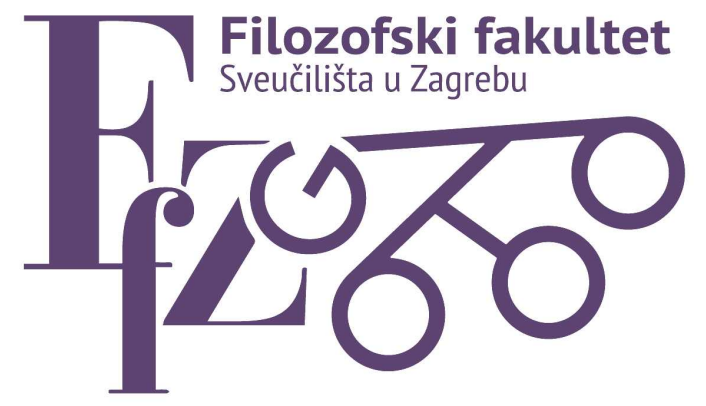

Repository / Repozitorij:

ODRAZ - open repository of the University of Zagreb Faculty of Humanities and Social Sciences
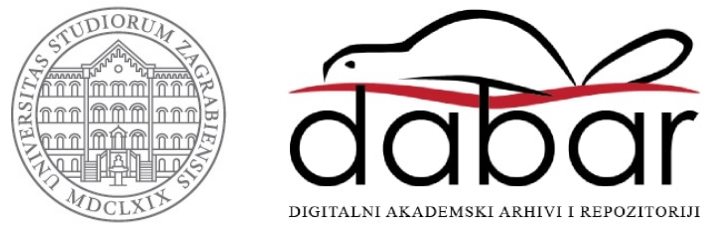


\title{
A COMPARATIVE AND DIACHRONIC ANALYSIS OF FILM TITLE TRANSLATIONS AND APPELLATIVE EFFECT TRANSFER into Croatian and German
}

\section{Petar Gabrić, Iva Brajković, Letizia Licchetta, Juraj Bezuh and Dorotea Kelčec Ključarić}

\begin{abstract}
Studies of film title translations remain scant to this day. The existing studies mainly focus on investigating the sources of difficulties during the translation process. Although the studies employ different analytical approaches, the conclusion in almost all investigations is that the decisive objective during the translation process is the transfer or production of the appellative effect. This study investigates which strategies are employed during translation into Croatian and German and why, as well as possible diachronic changes in the choice of translation strategies. We created a corpus of 935 film titles from 1923 to 2017 and their translations into Croatian and German, which we first classified as direct translation, free translation, transcreation or transcription, and finally we quantitatively and qualitatively analysed the data. Our results show considerable differences between the two subcorpora in the choice of translation strategies and motivation, as well as in the patterns of diachronic change. Furthermore, correlations with specific culturalhistorical processes are observed.
\end{abstract}

\section{Introduction}

Film titles have been understood as having a prominent role in one's perception, thus also in one's understanding, of a film. A title is defined as a paratext type, as are prefaces, postfaces, dedications, remarks and subheadings (Genette, 1989: 810). A paratext is an addition to the text which can have various functions, such as guiding the reader's interpretation. Titles are easily recognisable visually, as they normally precede the text; they are significantly shorter than the text itself, and 
they are graphically pronounced (Iannelli 1998: 26). Šidiškytè and Tamulaitienè (2013: 71) assert that film titles are "the most salient and eye-catching part and would rightly deserve a more extensive and systematic linguistic research". A title is thus given an important communicational role through which it mediates between the addressee of the text to which it belongs and the text it entitles (Peña-Cervel 2016: 305).

\section{Theoretical framework}

\subsection{Functions of titles}

During linguistic production, every sender performs a speech act that can be described in terms of several linguistic functions. In his organon model, Bühler (1934: 28) differentiates between three prominent functions of the linguistic sign: the representative function, which stands for a link between the linguistic sign and the referent in an extralinguistic reality, the expressive function, through which a link is formed between the realised message and the sender by transmitting the mental states of the sender, and the appellative function, which stimulates the addressee into action. All three functions are present during communication, and one of them always dominates. These linguistic functions, proposed by Bühler and Jakobson, have been successfully applied to titles in the field of translation studies.

Nord (1995: 264), for example, discriminates between three essential and three optional functions. The essential functions include the distinctive, the metatextual and the phatic function. The distinctive function relates to the uniqueness of the title in a particular culturally specific corpus. Iannelli (1998: 31 ) notes, however, that in some cases the expansion of the title is necessary for it to maintain its distinctive function. Thus sometimes titles of homonymous literary works such as Satires or Novellas need to include the name of the author or epoch, or some other name. Iannelli further mentions that titles of similar expression have been known to cause interference, such as with the titles of two works of Immanuel Kant Kritik der reinen Vernunft 'critique of pure reason' and Kritik der praktischen Vernunft 'critique of practical reason'. 
Moreover, information about the genre is conveyed through Nord's metatextual function since it has been noted in translation research that the formation of titles and their translations depend on the genre's conventions of a particular market.

The phatic function enables the creation of the communication channel and also message consolidation (Nord 1995: 264; Katnić-Bakaršić 1999: 3). The phatic function of a title can have a prominent role even in the absence of the text, which is important for maintaining the consumer's interest in the product (Boucheri 2008: 30).

Optional functions include, according to Nord (1995), the referential, the expressive and the appellative function. The referential function refers to information directly transmitted through the title. The sender's mental states are relayed through the expressive function. It has been noted that specific lexical-semantic structures can enhance the expressive effect, such as diminutives, superlatives, verbs in the first person, lexemes with salient emotional connotations, possessive pronouns etc. (Nord 2011: 64). The appellative function encourages the addressee to act (Nord 2011: 62-3).

Most studies concerned with film title translation have noted that the appellative effect is given the foremost attention during title production and translation (Schubert 2004; Limon 2012; Peña-Cervel 2016; Surdyk and Urban 2016; Jutronić and Karabatić 2016). In the context of film titles and their translations, the appellative effect relates to the efforts aimed at encouraging as many people as possible to watch the film. It is therefore no wonder that film title translation has been associated with skopos theory (Schubert 2004: 240). Although relatively clear boundaries between specific linguistic functions, or rather effects, have been made above, it has also been proposed that virtually all linguistic functions of titles have the potential of enhancing the appellative effect (Leonardi 2011: 10). An increase in the metatextual effect, by for example adding genre key words, and in the expressive effect, by adding emotionally salient lexemes, has been correlated with an increase in the appellative effect (Leonardi 2011: 17). Some authors have even gone so far as to say that film title translation is nothing more than appellative effect 
transfer (Schubert 2004: 241), while Jutronić and Karabatić (2016: 103) have equated film title translation strategies with marketing strategies.

\subsection{The process of film title translation}

The amount of shared knowledge about the process of film title translation has been modest at best. While it is clear that film texts are translated by professional translators, the role of the translator in film title translation seems to be quite tenuous. Studies of film title translations have not been particularly concerned with the translation process, although such information probably would shed some light on the apparent appellative behaviour of film title translations. Most studies claim that film titles are translated first and foremost, or even solely, by film distributors (Jutronić and Karabatić 2016: 103; Limon 2012: 8; Peña-Cervel 2016: 307). While sources of such information have mostly been unclear, Limon states that his knowledge about the translation process in Slovenia stems from conversations with four film distributors and the Slovenian public broadcaster Radiotelevizija Slovenija. Limon notes that cinema film titles are translated mostly by distributors, while the translation of film titles shown on television falls within the domain of the broadcaster. However, in some cases an already existing title translation is adopted, for example when the film text is based on a literary work (Limon 2012: 9). Šidiškyte and Tamulaitiene (2013: 75) have also observed that a title translation into one language can determine the translation into another language. The authors exemplify this with the film title Arbitrage (2012), which was translated into Lithuanian as Apgaulinga aistra 'deceptive passion' and into Russian as Порочная страсть 'vicious passion' whereby the authors assume that the Russian translation influenced the one made in Lithuania. A similar situation has been detected in Slovenian translations, where in a limited number of cases German translations seem to determine the final form of the title translation in Slovenian (Limon 2012: 9).

In order to examine the process of film title translation in Croatia and Germany we talked to Branimira Borčić Nemec, head of the Translation Department at the Croatian Radio and Television (HRT), which is the Croatian national broadcasting 
company, Henning Bochert, from the translation agency Bochert Translations in Berlin, and Timm Oberwelland, from the independent distribution company TOBIS Film GmbH in Berlin. We attempted to contact Croatian film distributors as well, but our calls were not returned. Borčić Nemec states that translators at the Croatian Radio and Television are actively involved in title translation. The translator suggests potential title translations; however, the final translation is chosen by the editor of the film department. A language editor is also involved in the process. Borčić Nemec notes that there are specific rules at the Croatian Radio and Television limiting possible translations. For example, foreign words are avoided when possible, normative accuracy is praised, while puns and wordplay are encouraged. Translators also seek to be as faithful to the original as possible and to maintain a connection to the film text. If a film title has already been translated, a translator may suggest a new translation if they have valid arguments. This is, however, typically not the case if a translation has been listed in the Film Encyclopedia (Filmska enciklopedija; Peterlić 1986a; Peterlić 1986b) published by the Miroslav Krleža Institute of Lexicography; such translations can only be modified in exceptional cases.

Bochert claims that, as a translator of feature films for Netflix, he has not wielded any influence on title translation, which is controlled by marketing. Bochert notes that before the 1980 s film titles were mostly directly or freely translated, while today the original titles are often transcribed and adopted as translations. In addition, the strategy of using expanded titles - which includes a German addition alongside the original English title - is widely used in Germany. Bochert connects this strategy with advertising, considering the fact that title addition has the function of a slogan for the film, but it is also connected with, as he states, the tendency to create a balance between the great influence of English in Germany and the status of German as the official and national language. Given that foreign films are mostly dubbed, viewers do not find this strategy unusual because it is perceived as a minor intervention on the part of the translator from the perspective of the viewer when the film is already dubbed in its entirety. Bochert also mentions the role of film studios when choosing a translation strategy. Studios sometimes require that the title be left unchanged, which must be respected by the distributors and others who are involved. Wordplay is used in Germany, as it is by the Croatian Radio and 
Television, whenever possible. A TV broadcaster in Germany may change an existing title translation, as is the case in Croatia, even if the film was already shown in cinemas. Bochert mentions the title of the film The Astronaut's Wife (Ravich 1999), which has two translations in Germany, one for the cinema (Die Frau des Astronauten 'the astronaut's wife') and another for television (Die Frau des Astronauten - Das Böse hat ein neues Gesicht 'the astronaut's wife - evil has a new face'). The first translation is a direct translation of the original, while the other has an addition alongside the direct translation of the original title. The title addition gives extra information about the genre and the plot of the film, thus fulfilling its advertising function, which is to attract a large number of viewers.

In order to determine how film distributors decide on the translation of a film title, we consulted Timm Oberwelland from the independent distribution company TOBIS Film GmbH based in Berlin. The company deals in the distribution of German and foreign films screened in Austria, Germany and Switzerland. The advertising department of the company, which includes no translators, decides on the translation of a film title, thus confirming the minor or even non-existent role of professional translators in the process of film title translation. Oberwelland explains that the company buys screening rights for films in duration from 15 to 20 years. The license is valid for screening films on all distribution channels: the cinema, television and the Internet. Each year they buy the rights for 15 films. The contract, which the company makes with film producers, determines all commercial aspects of the film on the new market: the film poster, the advertising budget and the film title, which means that the licensor must agree with the chosen poster and title. The distributors are also responsible for the subtitling and dubbing for the German market. This part of the work is done by translators employed as freelancers. Last year they translated titles using the transcreation strategy [e.g. Viceroy's House (2017) > Der Stern von Indien 'the star of India'], direct translation [e.g. Paris Can Wait (2016) > Paris kann warten] and transcription [e.g. Bad Moms (2016)].

The influence of the English language on the German market is related to social networks, through which the potential viewers often hear of a film for the first time and of its original title, which is usually in English. Therefore, distributors sometimes 
decide to keep the original English title since its translation would be a bad marketing move, especially if it is a film featured in foreign and German media for winning a prestigious award. Oberwelland states the example of the film 12 Years a Slave (2013), which was shown in Germany under the exact same title because the distributors thought that the appellative function was more powerful when using the original title.

The choice of a translation can also be influenced by the title translation of the literary work the film is based on. If a film is based on a book which was translated into German prior to the distribution of the book-based film, distributors will use the book's title translation as in the example of P. S. I Love You (2007), which was translated into German as P. S. Ich liebe dich 'P. S. I love you'.

When translating film titles, distributors seek to transfer and, if possible, amplify the appellative effect. Oberwelland thus mentions the film The Last Word (2017) where the title was not directly translated into German although this was possible; it was rather distributed under the title $Z u$ guter Letzt 'at long last'. The decision to change the title was made because the direct translation would have the negative connotation of finality which creates the mental image of the ultimate piece in a sequence, whereas the German title translation has a more positive connotation since it only signifies the end of a well-rounded unit.

The advertising function of a title determines the success of a film on the market. Therefore, it can happen that a film is more successful on a foreign market than on its original market thanks to a more explicit title. This can be seen in the example of A Little Chaos (2014), which was commercially more successful on the German market. Oberwelland attributes this fact to the transcreation of the title into Die Gärtnerin von Versailles 'the gardener of Versailles' which expresses the film's plot more explicitly and strengthens the appellative effect of the title.

\section{Approaches to the study of film title translation}

Early studies concerned with titles mostly examined the titles of literary works, especially novels. Film titles were only sometimes taken into account, mostly to establish a comparative perspective. These studies compared literary works and film 
titles with the titles of scientific papers (Bouchehri 2008: 33). Despite the early involvement of film titles in title research and the apparent progress in translation research in the last decades, studies of film title translations remain scant to this day (Peña-Cervel 2016: 307). Previous film title translation research can be divided into the Asian, primarily Chinese, and European geographical and cultural circles. Asian studies have mostly been interested in translation strategies of domestication and foreignisation (Yin 2009; Shi 2014; Mei 2010), while transliteration has been specifically addressed due to different writing systems used in the dominant source market, the United States (Beier et al. 1994: 5) and target markets (Yin 2009: 1712 ). European studies have been chiefly engaged in detecting the sources of difficulties during the translation process (Leonardi 2011; Limon 2012; Berdis 2013; Šidiškytè and Tamulaitienè 2013; Jutronić and Karabatić 2016; Surdyk and Urban 2016). Limon (2012: 1-2), as well as Surdyk and Urban (2016: 153), cite repeated criticism of film and television show title translations by viewers as expressed on internet fora and similar platforms as a reason for embarking on film title translation research.

Almost all studies of film title translation analysed one source and one target language. Only Šidiškytè and Tamulaitienè (2013) conducted a comparative analysis of the translation of English comedy and thriller titles into Lithuanian and Russian, but found no significant differences. The only diachronic analysis we encountered was Schubert's (2004), in which he detected significant diachronic changes in the translation strategy choice for German translations of English film titles. In his corpus containing titles from 1944 to 2002, Schubert noted a dramatic increase in the number of transcriptions, which have been the first strategy choice since the 1964-1973 decade, after being only modestly represented in the 1944-1953 decade. This change is interpreted as resulting from globalisation effects and the immense effect of English on German (Schubert 2004: 257). Schubert's 2004 study is also the only notable study involving German film title translations, while Jutronić and Karabatić (2016) remain the only study with Croatian film title translations. Jutronić and Karabatić (2016: 101-2) concluded in their study that the appellative effect serves as the primary motive during the process of title translation. Negro Alousque (2015) and Peña-Cervel (2016) conducted cognitive analyses of film title 
translations. However, the methodology and interpretations in the studies seem somewhat controversial.

Methodologically, most studies have relied on a classification of translation strategies developed on the basis of different types of manipulation of lexicalsemantic structures of the original title during the translation process. Schubert (2004) used the most detailed classification, which we used in our own analysis in a slightly modified form. Our modified classification includes the following translation strategies:

1. Direct translation [e.g. The Sixth Sense (1999) > Cr. Šesto čulo] is semantically similar to the original. A direct translation is a sign that the translator of the title did not encounter cultural and/or specific linguistic difficulties (Schubert 2004: 242). However, certain connotations have been known to get lost in a direct translation due to cultural and/or specific linguistic differences between the source and target languages. Schubert exemplifies this with the translation of the title The Color of Money (1986) into German (Die Farbe des Geldes) where the colour green marking the currency of the source market is invoked in the original title, but no such connections are elicited in the German translation. It is clear that the definition of direct translation is highly dependent on the particular semantic theory used in defining the concept. Direct translations were often not the focal point of film title translation studies, as most studies were preoccupied with the sources of difficulties in the translation process.

2. Free translation is a translation which has survived specific modifications, but has retained some semantic equivalence. Modifications taken into account in this study include addition, subtraction, substitution and shift.

a. Addition [e.g. Dawn of the Dead (2004) > Cr. Zora živih mrtvaca 'dawn of the living dead'] is an enlargement of the original title during the translation process by joining new lexical-semantic structures. Several studies analysing different languages noted that specific lexicalsemantic structures were systematically included in additions such as 
emotionally salient lexemes and proper nouns (Leonardi 2011: 14; Schubert 2004: 245).

b. Subtraction [e.g. Everything You Always Wanted to Know About Sex * But Were Afraid to Ask (1972) > Cr. Sve što ste željeli znati o seksu 'everything you wanted to know about sex'] is a partial removal of lexical-semantic structures during the translation process. Studies have noted that at least some subtraction cases are encouraged by exceedingly long titles, such as Who Is Harry Kellerman and Why Is He Saying Those Terrible Things About Me? (1971), which was translated into German as Wer ist Harry Kellerman? 'who is Harry Kellerman' (Schubert 2004: 242-3).

c. Shift [e.g. To Catch a Thief (1955) > Uhvatite lopova 'catch ${ }_{\text {IMP 2. PL the }}$ thief'] is defined as a change of morphosyntactic structures during the translation process (Schubert, 2004: 243; cf. Catford 1965: 76). Schubert (2004: 244) suggests that shifts in translations into German obscure the meaning of the title in some cases, thus enabling multiple interpretations, which presumably intensifies the appellative effect of the translation. However, his idea is arguable. Another observation was an increase in dynamics through the conversion of a nominal phrase into a verbal one, e.g. Ferris Bueller's Day Off (1986) > Ge. Ferris macht blau 'Ferris skips school'.

d. Substitution [e.g. House on Haunted Hill (1959) > Cr. Kuća straha 'house of fear'] includes a swap of lexical-semantic structures while morphosyntactic relations to other structures of the title remain relatively intact. Since in our preliminary analysis we found that morphosyntactic structures often experience at least some change when undergoing substitution, substitution is here defined more loosely compared to other translation strategies and could therefore be easily understood as a combination of addition and subtraction. Studies have indicated that specific lexical-semantic structures take the role of substitutes, such as highly concrete and emotionally salient lexemes 
which, as in addition, supposedly reinforce the appellative effect (Schubert 2004: 243).

3. Transcreation [e.g. American Beauty (1999) > Cr. Vrtlog života 'vortex of life'] is a complete replacement of lexical-semantic structures during the translation process, which results in zero linguistic equivalence. Translation research has differentiated between obligatory and optional transcreations, depending on potential cultural and/or linguistic difficulties during the translation process (Limon 2012: 6; Schubert 2004: 246). Problematic cases include idiomatic expressions and titles with multiple possible interpretations. Studies analysing Slovenian and German title translations have interpreted transcreation as, among other, a means of explication (Limon 2012: 4; Schubert 2004: 246-8). Limon concluded in his study that $41.3 \%$ of free translations and transcreations in his corpus included changes in the original title for the purposes of explication in order to more clearly convey the genre of the film and thus to target the appropriate audience. Schubert has suggested that a great deal of German transcretions show a tendency for personalisation, e.g. First Blood (1982) > Ge. Rambo 'proper name', or include emotionally salient lexemes. It is a general agreement that transcreations are mainly due to intentions of enhancing the appellative effect (Surdyk and Urban 2016: 168).

4. Transcription - Transcription is a strategy whereby exact lexical-semantic structures from the original title are retained, with possible modifications. Jutronić and Karabatić (2015: 87) found a considerable amount of transcriptions in their analysis of Croatian translations and linked this phenomenon to the high degree of prestige that English has among Croatian speakers.

a. Complete transcription [e.g. Spider-Man (2002) > Cr. Spider-Man 'proper name'] indicates the identity in expression between the original title and the translation. Studies have shown that this is often the case with original titles consisting of only proper nouns (Schubert 2004: 251-3). However, complete transcriptions have been known to lose phonetic associations, as is the case in Major Payne (1995), which was 
transcribed into Slovenian, thus eliminating the association caused by the homophonic expressions Payne and pain, both [pern] (Limon 2012: 2).

b. Additions [e.g. Octopussy (1983) > Ge. James Bond: Octopussy] mostly include subheadings, as noted by Schubert (2004: 249-51). While some subheadings have the role of explication, some are "semantically relatively empty" ${ }^{1}$. According to Schubert, such "nonsense titles" still deliver an increase to the appellative effect and are found first and foremost in mainstream comedies.

c. Subtraction [e.g. The Karate Kid (1984) > Cr. Karate Kid] is rarely found among transcriptions (Schubert 2004: 251).

d. Substitution [e.g. Pirates of the Caribbean: Dead Man's Chest (2006) > Pirates of the Caribbean - Fluch der Karibik 2 'curse of the Caribbean $\left.2^{\prime}\right]$ is equally rare (Ibid.).

During the analysis we established that some film title translations did not fit any of our proposed translation strategies. We were therefore compelled to expand our classification. The mixed type of free translation was added, characterised by two or more subtypes of modifications. Furthermore, combinations of translation, either direct or free, and transcription were detected, but remained quantitatively very limited and were consequently excluded from the qualitative analysis.

For the diagrams, please see Appendix 2.

\section{Aims and hypotheses}

The aim of this study was to analyse strategies employed in film title translation into Croatian and German and to discern specific strategies employed in the appellative effect transfer. This would allow us to detect valuable research points which could be pursued in future studies to increase our understanding of the film title translation process.

1 "Semantisch relativ leer" (translated by the authors). 
We hypothesised that the Croatian and German film title translations would show quantitative differences in the choice of translation strategies. We further hypothesised that diachronic changes would be detected in both subcorpora and that the two subcorpora would show some similarities in the change of diachronic patterns due to globalisation effects and that the patterns could be correlated with specific cultural-historical processes. In addition, we hypothesised that most of the recognised patterns in the analysis could be explained with the help of the appellative effect transfer.

\section{Methodology}

We manually created a corpus consisting of 935 original film titles in various languages and their 915 Croatian and 914 German translations. The full corpus is available in Appendix 1. We focused on a timeframe from 1923 and 2017. The selected timeframe was segmented into 10 -year periods, enabling us to calculate the proportion of particular translation strategies for each period. For each year, 10 original film titles with the highest number of votes were included in the corpus. We used this criterion in order to analyse the appellative effect transfer, as we assumed that the number of votes would correlate with the number of viewings of a film. Not all film titles had both the Croatian and German translation. Furthermore, some original titles were already in German. There were no original titles in Croatian. Every title was translated into at least one of the analysed target languages. Original titles were mostly in English, as was the case in all studies dealing with film title translation we reviewed (Schubert 2004; Mei 2010; Leonardi 2011; Limon 2012; Berdis 2013; Šidiškytè and Tamulaitienè 2013; Negro Alousque 2015; Jutronić and Karabatić 2016; Surdyk and Urban 2016; Peña-Cervel 2016). Other source languages in our study include, in order of frequency, French (30), Italian (15), German (15), Japanese (14), Russian (6), Swedish (4), Spanish (3), Latin (1), Korean (1), Portuguese (1) and Danish (1). Original titles were obtained from the website IMDb (Internet Movie Database; imdb.com), an online database offering 
relevant information on films, television shows and video games ${ }^{2}$. IMDb was used in corpus building by other relevant studies as well (Schubert 2004; Berdis 2013; Surdyk and Urban 2016; Peña-Cervel 2016).

Most title translations into Croatian were gathered from the online edition of the Film Lexicon (Filmski leksikon; Kragić and Gilić 2003) published by the Miroslav Krleža Institute of Lexicography (film.lzmk.hr) and the websites filmski.net, mojtv.hr, moj-film.hr and blitz-cinestar.hr. Two of these websites, mojtv.hr and mojfilm.hr, were used by Jutronić and Karabatić (2016) in their study as well. Translations into German were retrieved from the websites moviepilot.de and cineplex.de. In some cases, during our preliminary analysis, we encountered German translations specific for the Swiss and Austrian markets. These title translations were excluded from the analysis. We were presented with a similar situation in the Croatian subcorpus where we came upon Croatian translations specific for the Bosnian market. These translations were excluded as well. Thus we could focus specifically on the Croatian and German markets.

The first step in the corpus analysis was to classify the film title translations according to specific strategies found in our classification presented earlier (Section 3). The data was quantitatively and qualitatively analysed for each target language separately and then compared.

In our diachronic analysis, we calculated the proportion of particular translation strategies for each 10-year period from 1923 to 2017 . Since we wanted to offer a preliminary explanation for potential diachronic changes, we compared the temporal perspective of some diachronic changes with the timeline of relevant culturalhistorical processes that presumably had global influence. Special attention was given to processes occurring in the American film industry, or Hollywood, as that was the source of most of the analysed film titles. Hollywood became a notable place in the global film industry during and immediately after World War II. At this time the European film industry came to a halt, enabling Hollywood's domination of the industry. However, at the end of the 1950s and the beginning of the 1960s,

2 Surdyk and Urban (2016: 157) describe IMDb as "the world's most popular and authoritative source for movie, TV and celebrity content". 
Hollywood entered a period of stagnation (Peterlić 1986: 557). During that time there was also a reduction in the number of cinemas in Germany (Lorenzo 2015: 109). From the 1960s to the 1980s the so-called era of New Hollywood began, characterised by the strengthening of the director's artistic role; at the same time the major film studios engaged primarily in film distribution and global marketing (Peterlić 1986: 535). A distinction is made between early New Hollywood, also called Hollywood Renaissance, which ended in the second half of the 1970s, and the Late New Hollywood (Kokonis 2008: 171). In the 1990s multiplex cinemas came to the forefront, which shifted the focus to massive film projections through which the number of cinema goers drastically increased, both in the US and in Germany (Lorenzo 2015: 110).

\section{Results and discussion}

\subsection{Comparative analysis}

In most cases (60.1\%) film titles were directly translated into Croatian. Direct translation was followed by free translation (17\%) and transcription (15.5\%). Transcreation was represented by $6.7 \%$ of the title translations, while combinations of a translation and transcription were scarce $(0.8 \%)$. Film titles were chiefly transcribed into German (39.7\%), while direct translation was also considerably represented $(25.4 \%)$. These were followed relatively closely by transcreation (17\%) and free translation (16.8\%). Combinations of a translation and transcription were, similarly to the Croatian subcorpus, limited to $1 \%$.

\subsubsection{Direct translation}

Direct translation was considerably more represented in the Croatian subcorpus than in the German one. Some original titles in our corpora were directly translated although there were clear cultural and/or linguistic difficulties in the translation process. For example, the film title $V$ for Vendetta (2005) was directly translated into Croatian as $O$ za osvetu even though the grapheme $V$ is a relevant visual motive in the film. Furthermore, we observed direct translations that were identical to the 
translation of a literary title on which the plot of the film was based, e.g. War of the Worlds (2005) > Rat svjetova. However, it is difficult to assess whether the title was translated anew or if the previous translation of a literary title was adopted. Nevertheless, it could be presumed that the adoption of an already existing translation could add to the appellative effect of the translation through the serial effect, which is "the consumer's belief that new products from the same group have a constantly high quality" ${ }^{3}$ (Schubert 2004: 247).

\subsubsection{Free translation}

Free translation as a whole was present in similar proportions in both subcorpora. Croatian free translations were led by shifts $(29.9 \%)$, which were closely followed by substitutions (26.8\%) and additions (21.7\%). Subtraction and the mixed type appeared in slightly lower proportions, $13.4 \%$ and $8.3 \%$ respectively. German translations were dominated by substitutions (36.4\%), which were followed by shifts $(18.8 \%)$, subtractions $(17.5 \%)$, additions $(16.2 \%)$ and the mixed type $(11 \%)$. Subtle differences between the two markets are observable.

When it comes to additions, there were some differences between the two subcorpora. A closer look at additions in the Croatian subcorpus reveals that in most cases the motivation for additions can be discerned. In $32.4 \%$ of the cases there is a tendency of enhancing the serial effect by adding lexical-semantic structures indicating that the film is part of a series, e.g. The Man with the Golden Gun (1974) > Cr. James Bond 007: Čovjek sa zlatnim pištoljem. Interestingly, most of the serial markers include character names. Addition seems also to have served as a means of explication, at least in $23.5 \%$ cases, e.g. Airplane! (1980) $>$ Cr. Ima li pilota u avionu 'is there a pilot on the plane'. Sometimes keywords for the explication of a genre were also involved, Dawn of the Dead (1978) > Cr. Zora živih mrtvaca 'dawn of the living dead'. The addition of emotionally salient lexemes was discovered in only four cases (11.8\%) and included in two instances the abstract lexeme DEATH, a diminutive and an attribute. As was the case with the Croatian subcorpus, German

3 "Dem Glauben der Konsument(inn)en, dass neue Produkte aus derselben Gruppe eine konstant hohe Qualität aufweisen" (translated by the authors). 
additions had the role of creating the serial effect (in 37.5\% of the cases), e.g. Sons of the Desert (1933) > Ge. Laurel und Hardy: Die Wüstensöhne 'Laurel and Hardy: the desert sons'. The proportion of emotionally salient lexemes was somewhat higher in the German subcorpus, with $25 \%$ of the translations which were mostly expanded with the use of attributes. In four cases (16.7\%) character names were introduced to the title, without having the purpose of achieving the serial effect, e.g. The Martian (2015) > Ge. Der Marsianer - Rettet Mark Watney 'the Martian - save Mark Watney'. There were no such cases in the Croatian subcorpus.

Regarding addition, we also observed that in both subcorpora most additions include series markers and, interestingly, their proportions are comparable. This suggests that original titles of films belonging to a series which are not marked as such are similarly treated both in Croatia and in Germany. Contrary to these similar trends in the process of marking the affiliation to a series, there were no cases of explication in the German subcorpus, while this motivation was highly represented in the Croatian subcorpus. Moderate differences were present in the proportions of emotionally salient lexemes, the higher proportion being found in the German subcorpus. Personalisation was modestly present only in the German subcorpus. Although it is difficult to judge which of the motivations would produce a greater appellative effect, these results possibly suggest that the orientation towards a more powerful appellative effect was more present during the translation process into German than into Croatian.

Subtraction was present in similar proportions in both subcorpora. In the Croatian subcorpus, $38.1 \%$ of the subtractions excluded a redundant series marker. In all of these cases, original titles include either the marker part or episode (which incidentally only appears in titles of the Star Wars film series). One example is The Hangover Part II (2011) > Mamurluk 2 'hangover 2'. Subtraction resulting from the shortening of an exceedingly long title was also present in $38.1 \%$ of the cases. In most cases (75\%) the subheading was lost, e.g. The Naked Gun: From the Files of Police Squad! (1988) > Goli pištolj 'naked gun'. In the German subcorpus, the shortening of an exceedingly long title was present in $25.9 \%$ of the cases, e.g. The Lodger: A Story of the London Fog (1927) > Der Mieter 'the lodger'. There were 
some cases (14.8\%) of a redundant marker exclusion, e.g. The Godfather: Part III (1990) > Der Pate 3 'the godfather 3'. Apart from a single case when an already existing literary title translation was adopted, motivations for all other subtractions in the German subcorpus remain unclear. While the obvious trend in the Croatian subcorpus was to shorten long original titles, possibly to allow greater clarity, the percentage of shortening was considerably lower in the German subcorpus.

The proportions of shifts show moderate differences between the two subcorpora. What is perhaps more notable is that shifts and substitutions appear in similar proportions in the Croatian subcorpus, while their proportions are rather different in the German subcorpus, where substitutions are favoured over shifts. Initially one might assume that a higher proportion of shifts in the Croatian subcorpus can be explained by greater morphosyntactic differences between Croatian and English as the prevailing source text, as opposed to German and English. However, a closer look shows that only $12.8 \%$ of the shifts in the Croatian subcorpus can be interpreted as interventions due to morphosyntactic differences between the source languages and Croatian, e.g. He Who Gets Slapped (1924) > Onaj kojega su tresnuli 'the one who they slapped', where the passive construction was hard to transmit. There were three cases $(6.3 \%)$ of salient emotional connotations resulting from a shift. For example, in The Thin Man (1934) > Mršavko 'thin-suffix', instead of a lexeme equivalent to MAN, the suffix - $k o$ is inserted which nominalises the adjective, denotes a person and functions as a hypocoristic (Barić et al., 2005: 329). Only two cases (4.2\%) of explication were detected, e.g. Roman Holiday (1953) > Praznik u Rimu 'holiday in Rome'. Remarkably, motivation in other cases remains enigmatic. In the German subcorpus, $20.7 \%$ of the shifts were due to morphosyntactic differences between the languages, e.g. Edward Scissorhands (1990) > Edward mit den Scherenhänden 'Edward with the scissor hands'. Yet other cases of shifts continue to be unclear. Although for reasons of linguistic typology one might expect a higher proportion of shifts in the Croatian subcorpus than in the German one, they are actually similar and slightly more substantial in the German subcorpus. It would appear that, when encountering difficulties due to the morphosyntactic differences between the source and target languages, translation strategies other than shifts are implemented in the translation process. Although the 
proportion of explication was very low in the Croatian subcorpus, it seems rather indicative that there were yet again no explication cases in the German subcorpus.

Substitutions were moderately more numerous in the German subcorpus compared to the Croatian one. Once again most changes were made with unclear motivation. Both explication and interventions due to linguistic differences were modestly present at $14.3 \%$ in the Croatian subcorpus. An example with a clear difficulty was the original title (500) Days of Summer (2009) which was translated into Croatian as (500) dana ljubavi '(500) days of love'. The difficulty was caused by the homonymy between the English lexeme SUMMER and the character name Summer, which was impossible to convey in the translation. Five cases (11.9\%) included emotionally salient lexemes as substitutes, e.g. Ace Ventura: Pet Detective (1994) > Ace Ventura: Šašavi detektiv 'Ace Ventura: the wacky detective'. Most other cases of substitution remain vaguely motivated. Substitution was the most common subtype of the free translation strategy in the German subcorpus. Although motivation is unclear in most cases, first explication cases were detected in the German subcorpus, but they were present in only $9.1 \%$ cases. Substitutes in most interpretable cases were emotionally salient lexemes (23.6\%), e.g. Our Hospitality (1923) > Verflixte Gastfreundschaft 'darned hospitality'. Clear differences are noticeable between the two subcorpora. While in the Croatian subcorpus substitution had a role in the translinguistic reconciliation, no such aspect was detected in the German subcorpus. Yet again there were moderate differences in the proportion of emotional connotations, which were more substantial in the German subcorpus.

Free translation of the mixed type was modestly represented in both subcorpora. No systematic data was found in the analysis regarding free translation of the mixed type.

\subsubsection{Transcreation}

The proportion of transcreation showed mild differences between the two subcorpora, with the German subcorpus containing more instances of this strategy. In the Croatian subcorpus, $21.3 \%$ of the transcreations facilitated explication, e.g. Now You See Me (2013) > Majstori iluzije 'masters of illusion'. In 13.1\% of the cases 
emotionally salient lexemes were added during the transcreation process. Most other cases are without a clear interpretation. In the German subcorpus, a large number of transcreations did not have a clear interpretation either. In $9.3 \%$ of the cases an emotional connotation was introduced. In most of the cases the lexemes served for the explication of the genre, for example in White Heat (1949) > Sprung in den Tod 'the jump into death' where the translation suggests a thriller. In $7.4 \%$ of the cases a proper noun was inserted during the transcreation process, e.g. The Most Dangerous Game (1932) > Graf Zaroff - Genie des Bösen 'count Zaroff - genius of evil'. There were few cases of explication in the German subcorpus, making the proportion of such interventions in the Croatian subcorpus noticeably higher than in the German one. The proportion of lexemes with salient emotional connotations was similar in both subcorpora.

\subsubsection{Transcription}

There were pronounced differences in the proportion of transcription between the two subcorpora. While transcription was only modestly represented in the Croatian subcorpus, it was the primary choice in the German one. Croatian transcription was dominated by complete transcription $(88.1 \%)$, which was followed by subtraction $(9.8 \%)$ and addition $(2.1 \%)$. The latter strategy was represented by only three cases in the entire subcorpus. German transcription was also led by complete transcription (69.3\%), but included considerably more additions, which took the second position (24.3\%). Subtraction was found in $5 \%$ of the cases. In the German subcorpus, substitutions were found in only four cases, and there was a single shift. Considerable differences are, therefore, noticeable in the proportions of complete transcription and addition between the two subcorpora. The fact that the German subcorpus contained substitutions and a shift, which were not represented in the Croatian subcorpus, and the fact that most original titles from the corpus were in English, suggests that English lexical-semantic structures are more acceptable when translating into German than into Croatian. However, the proportion of both translation strategies remain very low, calling for further arguments for this kind of interpretation. 
The proportion of complete transcriptions was significantly higher in the Croatian subcorpus compared to the German one. Most complete transcriptions in the Croatian subcorpus were transcriptions of proper nouns (83.3\%), e.g. Mary Poppins (1964). In $13.3 \%$ of the cases proper nouns included compound proper nouns such as Iron Man or Spider-Man. There were six cases (4.8\%) of transcription in which there were either no clear lexical-semantic structures, e.g. THX 1138 (1971), or the source language was ambiguous, e.g. Ex Machina (2015). There was one case of number transcription $(0.8 \%)$, namely 300 (2006). Other cases of transcription have no clear motivation, but were quantitatively marginal. Contrary to the high proportion of clearly motivated complete transcriptions in the Croatian subcorpus, only $29.6 \%$ of the complete transcriptions in the German subcorpus are transcriptions of proper nouns. Cases similar to and including THX 1138 and EX Machina were found to constitute $2.4 \%$. The same case of number transcription was also found in the German subcorpus. Therefore, while $88.9 \%$ of the complete transcriptions in the Croatian subcorpus are clearly motivated, only $32.4 \%$ of the complete transcriptions in the German subcorpus fall into that category.

There were considerably more additions in the German subcorpus compared to the Croatian one, in which only three cases of such interventions were found. Two of these included serial markers, e.g. Octopussy (1973) > James Bond: Octopussy. Almost all cases of addition in the German subcorpus involved the insertion of subheadings (94.3\%), with only five titles remaining without a subheading. In $28.4 \%$ of the cases, additions involved lexemes with salient emotional connotations. As many as $68 \%$ of these cases had the purpose of genre explication, e.g. Halloween II (1981) > Halloween II - Das Grauen kehrt zurück 'Halloween II - the horror returns'. Although a preliminary visual examination suggests that most of the subheaded transcriptions are nonsense subheadings, one group that stands out is comprised of combinations of a complete transcription and a direct translation. Eleven such cases (12.5\%) were found, e.g. The King's Speech (2010) > The King's Speech - Die Rede des Königs 'the king's speech - the speech of the king'. There were limited amounts of explication and cases where series markers were used. 
Subtraction was found in similar proportions in both subcorpora. However, depending on the theoretical classification one wishes to pursue, it would seem appropriate to count a large proportion of subtractions in both subcorpora as complete transcriptions. In the German subcorpus, for instance, $77.8 \%$ of the cases are exclusions of the initial definite article, e.g. The Karate Kid (1984) > Karate Kid. This was the case in $57.1 \%$ of the cases in the Croatian subcorpus. Additionally there were three cases $(21.4 \%)$ of the exclusion of subheadings and three cases of the exclusion of redundant series markers in the Croatian subcorpus. In the German subcorpus, beside the initial definite article exclusion, in one case a subheading was excluded and in another a redundant series marker. Two cases had no clear motivation, e.g. Silver Linings Playbook (2012) > Silver Linings.

Substitutions and shifts were not found in the Croatian subcorpus, as already mentioned above. Four of the five cases in the German subcorpus include titles of films belonging to a series, the earliest being from 2006. The remaining translation is a fairly peculiar case of substitution: The Addams Family (1991) > Die Addams Family 'the Addams family'.

Translations in the German subcorpus systematically show lower proportions of explication compared to the Croatian subcorpus. Conversely, proportions of emotionally salient lexemes were higher in essentially all translation strategies investigated in our study. What is more, motivation for most modifications, when it comes to both free translation and transcription, was unclear in considerably more cases in the German subcorpus than was the case in the Croatian one. All this, along with the observed considerable differences in the diversity of transcriptions, suggests that the process of translation into German was much more modulated by the appellative effect transfer and increase, also allowing more room for the original appellative effect of English lexical-semantic structures. Because there were substantially more cases of explication and fewer cases of unmotivated transcreation and transcription in the Croatian subcorpus, clarity of title translation seems to be the central motivation in most cases. This interpretation is also supported by the fact that nonsense title transcriptions or nonsense subheadings were hard to find in the Croatian subcorpus, while they were abundant in the German one. 


\subsection{Diachronic analysis}

In the first examined decade, between 1928 and 1937, the Croatian subcorpus was greatly dominated by direct translations $(78.5 \%)$. Free translation and transcription appeared in much lower proportions ( $8.6 \%$ and $7.5 \%$ respectively). Transcreation and combinations of a translation and transcription (CTT) show marginal results. For the next several decades, moderate or in some cases slight fluctuations in the proportions of direct translation, free translation and transcription can be observed. Transcreation remained peripheral while CTTs were non-existent until 2006. In the 1978-1987 decade, a pronounced drop in direct translation was observed, from $73.7 \%$ in the previous decade to $49 \%$. Comparing those two decades, we further found a substantial increase in free translation, from $6.3 \%$ to $22.4 \%$, and a moderate increase in transcription, from $15.8 \%$ to $21.4 \%$. Most of the transcriptions from this decade involved proper nouns, which suggests that this increase is mostly or solely due to sampling bias. Free translations, however, do not show any clear cause from the translator's point of view, as there were virtually no interventions due to linguistic differences between the source languages and Croatian. In the next decades no significant diachronic changes were detected. Free translation retained a higher proportion, constantly around $20 \%$. Direct translation remained steady (around 50\%). Transcription regularly constituted $20 \%$ after the end of the 19881997 decade. Transcreation gradually increased after the 1948-1957 decade to a modest proportion, regularly just below $10 \%$. Diachronically, the most substantial changes were found in the proportion of direct translation, which dropped around $30 \%$ from the onset of our timeline. This was mostly picked up by free translation, which showed a moderate increase at one point and has remained at a similar level until present. Transcription recorded a moderate increase compared to the first decade, but the fluctuations observable from the second decade already showed values similar to the present ones. This led to the final decade still being dominated by direct translation $(46.5 \%)$, followed by transcription $(21.8 \%)$, free translation $(18.8 \%)$, transcreation $(8.9 \%)$ and CTTs $(4 \%)$.

In the first examined decade, between 1928 and 1937, direct translation was the first strategy choice in the German subcorpus, with $44.4 \%$. Other translation 
strategies shared similar proportions: transcreation $21.1 \%$, transcription $17.8 \%$ and free translation $16.7 \%$. The next two decades showed mild increases in transcreation and free translation, combined with a moderate decrease in direct translation. In the 1958-1967 decade, fluctuations are apparent in all strategies, while transcription recorded its first moderate increase. This increase gradually gained ground and exploded in the 1978-1987 decade, when transcription became the first choice translation strategy, making up $54.7 \%$ of the cases. Consequently, all other translation strategies recorded moderate or substantial drops. Direct translation went from $40.6 \%$ in the $1958-1967$ decade to $16.2 \%$ in the following decade. The trends have continued with limited fluctuations until today, when transcription is the predominant strategy $(75.2 \%)$, followed by direct translation $(8.9 \%)$, free translation $(7.9 \%)$, transcreation $(5.9 \%)$ and CTT (2\%). The last decade recorded only a moderate decline in free translation.

Diachronic differences and similarities can be observed between the two subcorpora. In both subcorpora we observed prominent decreases in direct translation. In the Croatian subcorpus, there was a pronounced drop in the 19781987 decade, while the German subcorpus recorded a similar drop in the 1958-1967 decade and a subsequent gradual decline in the periods approaching the last decade. It is, however, not clear why the observed change showed different temporal values. The gradual decline was probably a consequence of a steady rise in transcription. What is more, a similar gradual decline was recorded in free translation and transcreation as well. In the Croatian subcorpus, moderate changes were observed with regard to free translation, which does not seem to be a product of sampling bias.

Although not many major diachronic changes were detected in our analysis, we can still make some connections to specific cultural-historical processes. According to the general timeline presented in Section 5, the major decline in direct translation observable in the German subcorpus seems to correlate with the onset of New Hollywood, which was characterised by a shift in the focus of major film studios from the artistic control of the movie production to the distribution of the film and its success on the global market. That is also the time when fluctuations in all 
translation strategies appear in the German subcorpus, suggesting that culturalhistorical changes influenced the process of film title translation. It also possibly suggests that there was a period of adjustment, since steady proportions of particular translation strategies emerged only later. However, sampling bias should be taken as a possibly influential factor. The explosion of transcription in the 19781987 decade can be correlated to advances in Hollywood's power during the later phases of New Hollywood. However, causal links remain unclear, probably due to the quite general outline of cultural-historical processes we used in our analysis. In the same decade that transcription ballooned in the German subcorpus, the Croatian subcorpus experienced a substantial decrease in direct translation and a moderate increase in free translation. These results imply that there were notable connections between cultural-historical processes in the 1980s, and possibly sooner, and diachronic changes in film title translation. Because film title translators are more focused on the appellative effect at present, it is possible that free translation and transcription, in the Croatian and German subcorpora respectively, were those translation strategies that were mostly associated with the appellative effect transfer.

\section{Conclusion}

The analysis of our corpus consisting of 935 film titles between 1923 and 2017 and their translations into Croatian and German yielded considerable quantitative and qualitative differences in translation strategy choices and their motivation between the two subcorpora. The most notable differences have to do with the proportion of direct translation, which was lower in the German subcorpus from the start of our timeline, but further experienced substantial drops, and which was not as pronounced in the Croatian subcorpus. Differences in diachronic patterns were observed as well, but clear interpretations of temporal differences are more difficult to make. Almost all non-direct translation strategies were characterised as increasing or maintaining the appellative effect of the title. Furthermore, correlations with specific cultural-historical processes, although extremely general, were observed. Sampling bias was a serious threat to our proposed interpretation. We 
conclude that further research with bigger samples is needed to clarify the diachronic perspective.

\section{REFERENCES}

Berdis, Vratislav. 2013. English film titles and their Czech equivalents. Unpublished BA thesis. Brno: Masaryk University.

Böhnke, Alexander. 2007. Paratexte des Films. Über die Grenzen des filmischen Universums. Bielefeld: transcript Verlag.

Bouchehri, Regina. 2008. Filmtitel im interkulturellen Transfer. Berlin: Frank \& Timme.

Bühler, Karl. 1934. Sprachtheorie. Jena: Verlag von Gustav Fischer.

Catford, John Cunnison. 1965. A linguistic theory of translation: an essay in applied linguistics. London: Oxford University Press.

Genette, Gérard. 1989. Paratexte. Das Buch vom Beiwerk des Buches. Frankfurt am Main: Campus Verlag.

Iannelli, Ettore C. 2015. Riflessione sulla traduzione dei titoli dei film. Milan: S. I. Editore.

Jojić, Ljiljana. (ed.). 2015. Veliki rječnik hrvatskoga standardnog jezika. Zagreb: Školska knjiga.

Jutronić, Dunja. Karabatić, Tereza. 2016. "Translation of English feature films titles in Croatian". Zbornik radova Filozofskog fakulteta u Splitu 8: 85-103.

Katnić-Bakaršić, Marina. 1999. Lingvistička stilistika. Budimpešta: Open Society Institute.

Kokonis, Michalis. 2008. "Hollywood's Major Crisis and the American Film 'Renaissance'".

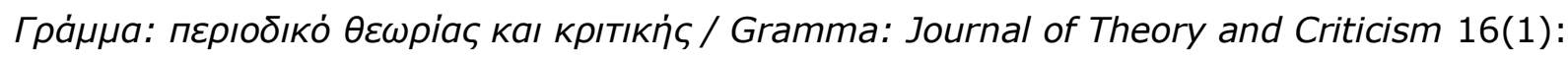
169-206.

Kragić, Bruno. Gilić, Nikica. (ed.). 2003. Filmski leksikon. A-Ž. Zagreb: Leksikografski zavod Miroslav Krleža.

Leonardi, Vanessa. 2011. "Translating film titles: linguistic skills, cultural awareness or marketing strategies?". Language, Communication and Social Environment 9: 180-201.

Limon, David. 2012. "Film titles and cultural transfer". Cultus: the Intercultural Journal of Mediation and Communication 5: 189-208. 
Lorenzo, Giovanni di. (ed.). 2015. Film: Geschichte des Films in Deutschland. Hamburg: Zeitverlag Gerd Bucerius GmbH \& Co. KG.

Mei, Zhongfang. 2010. "On the Translation Strategies of English Film Title from the Perspective of Skopos Theory". Journal of Language Teaching and Research 1(1): 66-68. Negro Alousque, Isabel. 2015. "The role of cognitive operations in the translation of film titles". Procedia - Social and Behavioral Sciences 212: 237-241.

Nord, Christiane. 1995. "Text-Functions in Translation: Titles and Headings as a Case in Point". Target 7(2): 261-284.

Nord, Christine. 2011. Funktionsgerechtigkeit und Loyalität: Theorie, Methode und Didaktik des funktionalen Übersetzens. Leipzig: Frank \& Timme GmbH Verlag.

Peña-Cervel, Sandra. 2016. "Motivating film title translation: a cognitive analysis". Círculo de Lingüística Aplicada a la Communicación 66: 301-339.

Peterlić, Ante. (ed.) 1986a. Filmska enciklopedija. 1, A-K. Zagreb: Jugoslavenski leksikografski zavod Miroslav Krleža.

Peterlić, Ante. (ed.) 1986b. Filmska enciklopedija. 2, L-Ž. Zagreb: Jugoslavenski leksikografski zavod Miroslav Krleža.

Ravlić, Slaven. 2006. Hrvatska enciklopedija. 8, O-Pre. Zagreb: Leksikografski zavod Miroslav Krleža.

Schubert, Christoph. 2004. "Die Appelwirkung englischer Filmtitel und ihrer deutschen Neutitel: Techniken interkulturellen Transfers". AAA - Arbeiten aus Anglistik und Amerikanistik, 29(2): 239-259.

Surdyk, Augustyn. Urban, Anna. 2016. "Mistranslations of Film Titles: Between Fidelity and Advertising". Glottodidactica 43(1): 153-170.

Šidiškytè, Daiva. Tamulaitienè, Daiva. 2013. "The Contrastive Analysis of the Translation of English Film Titles into Lithuanian and Russian". Kalbu studijos / Studies about Languages 22: 71-77. 


\title{
A COMPARATIVE AND DIACHRONIC ANALYSIS OF FILM TITLE TRANSLATIONS AND APPELLATIVE EFFECT TRANSFER into Croatian AND German
}

\section{Petar Gabrić, Iva Brajković, Letizia Licchetta, Juraj Bezuh and Dorotea Kelčec KIjučarić}

\begin{abstract}
Studies of film title translations remain scant to this day. The existing studies mainly focus on investigating the sources of difficulties during the translation process. Although the studies employ different analytical approaches, the conclusion in almost all investigations is that the decisive objective during the translation process is the transfer or production of the appellative effect. This study investigates which strategies are employed during translation into Croatian and German and why, as well as possible diachronic changes in the choice of translation strategies. We created a corpus of 935 film titles from 1923 to 2017 and their translations into Croatian and German, which we first classified as direct translation, free translation, transcreation or transcription, and finally we quantitatively and qualitatively analysed the data. Our results show considerable differences between the two subcorpora in the choice of translation strategies and motivation, as well as in the patterns of diachronic change. Furthermore, correlations with specific culturalhistorical processes are observed.
\end{abstract}




\section{A COMPARATIVE AND DIACHRONIC ANALYSIS OF FILM TITLE TRANSLATIONS AND APPELLATIVE EFFECT TRANSFER into Croatian AND German}

\section{Petar Gabrić, Iva Brajković, Letizia Licchetta, Juraj Bezuh and Dorotea Kelčec Ključarić}

\section{Sažetak}

Istraživanja o filmskim naslovima relativno su rijetka. Postojeća istraživanja bave se prvenstveno izvorima poteškoća u prijevodu. Iako se u tim istraživanjima koriste različiti analitički pristupi, zaključak je u gotovo svim slučajevima da je glavni cilj tijekom procesa prevođenja prijenos ili produkcija apelativnog efekta. U ovoj se studiji istražuje koje se strategije koriste tijekom prijevoda na hrvatski i njemački jezik te zašto. Također se istražuju i moguće dijakronijske promjene u izboru prijevodnih strategija. Sastavili smo korpus od naslova 935 filmova snimljenih od 1923. do 2017. te njihovih prijevoda na hrvatski i njemački jezik. Te smo naslove razvrstali u sljedeće kategorije: izravni prijevodi, slobodni prijevodi, transkreacije $i$ transkripcije. Na kraju smo kvantitativno i kvalitativno analizirali podatke. Rezultati naše studije pokazuju značajne razlike između dvaju potkorpusa u izboru prijevodnih strategija i motivaciji te u obrascima dijakronijskih promjena. Nadalje smo opazili $i$ korelacije s određenim kulturno-povijesnim procesima. 


\section{A COMPARATIVE AND DIACHRONIC ANALYSIS OF FILM TITLE TRANSLATIONS AND APPELLATIVE EFFECT TRANSFER into Croatian AND German}

\section{Petar Gabrić, Iva Brajković, Letizia Licchetta, Juraj Bezuh and Dorotea Kelčec Ključarić}

\section{Zusammenfassung}

Studien von Filmtitelübersetzungen sind nach wie vor schwer zu finden. Die bisherigen Studien richteten sich vor allem auf die Untersuchung von Schwierigkeiten beim Übersetzungsprozess. Obwohl die Studien verschiedene analytische Vorgehensweisen in Anspruch nahmen, ist die Schlussfolgerung fast aller Untersuchungen, dass der Transfer oder die Produktion des appellativen Effektes das Ziel der Filmtitelübersetzung ist. Diese Studie untersucht, welche Strategien bei der Übersetzung ins Kroatische und Deutsche eingesetzt wurden und warum genau diese; dazu auch mögliche diachronische Veränderungen bei der Wahl der Übersetzungsstrategie.

Wir stellten ein Korpus von 935 Filmtiteln von 1923 bis 2017 und ihren Übersetzungen ins Kroatische und Deutsche zusammen. Die Übersetzungen wurden zunächst eingeordnet, und zwar als direkte Übersetzungen, freie Übersetzungen, Umtitelungen und Transkriptionen. Schließlich haben wir die Daten quantitativ und qualitativ analysiert. Unsere Ergebnisse zeigen bedeutende Unterschiede zwischen den zwei Subkorpora in der Wahl der Übersetzungsstrategie und Motivation, sowie in den Mustern der diachronischen Veränderungen. Weiterhin wurden Korrelationen zu spezifischen kulturell-historischen Prozessen festgestellt. 


\section{A COMPARATIVE AND DIACHRONIC ANALYSIS OF FILM TITLE TRANSLATIONS AND APPELLATIVE EFFeCt tRANSFER INTO Croatian AND German}

Petar Gabrić, Iva Brajković, Letizia Licchetta, Juraj Bezuh, Dorotea Kelčec Ključarić

\section{Appendices}

\section{Appendix 1}

1. Croatian subcorpus

\subsection{Direct translations}

\begin{tabular}{|l|l|l|}
\hline La souriante Madame Beudet & 1923 & Nasmiješena gospođa Beudet \\
\hline Our Hospitality & 1923 & Naše gostoprimstvo \\
\hline The Pilgrim & 1923 & Hodočasnik \\
\hline The Ten Commandments & 1923 & Deset zapovijedi \\
\hline Entr'acte & 1924 & Međučin \\
\hline Greed & 1924 & Pohlepa \\
\hline The Navigator & 1924 & Navigator \\
\hline The Thief of Bagdad & 1924 & Bagdadski lopov \\
\hline Der letzte Mann & 1924 & Posljednji čovjek \\
\hline
\end{tabular}




\begin{tabular}{|c|c|c|}
\hline Die Nibelungen: Kriemhilds Rache & 1924 & Nibelunzi: Kriemhildina osveta \\
\hline The Gold Rush & 1925 & Potjera za zlatom \\
\hline The Big Parade & 1925 & Velika parada \\
\hline The Freshman & 1925 & Brucoš \\
\hline Bronenosets Potyomkin & 1925 & Krstarica Potemkin \\
\hline Stachka & 1925 & Štrajk \\
\hline The Phantom of the Opera & 1925 & Fantom opere \\
\hline The Lost World & 1925 & Izgubljeni svijet \\
\hline Mat & 1926 & Mati \\
\hline Die Abenteuer des Prinzen Achmeds & 1926 & Avanture princa Ahmeda \\
\hline The General & 1926 & General \\
\hline The Son of the Sheik & 1926 & Šeikov sin \\
\hline Flesh and the Devil & 1926 & Put i đavao \\
\hline Wings & 1927 & Krila \\
\hline College & 1927 & Koledž \\
\hline Berlin: Die Sinfonie der Grosstadt & 1927 & Berlin, simfonija velegrada \\
\hline The Kid Brother & 1927 & Mlađi brat \\
\hline The Lodger: A Story of the London Fog & 1927 & Stanar: Priča o londonskoj magli \\
\hline The Jazz Singer & 1927 & Pjevač jazza \\
\hline The Circus & 1928 & Cirkus \\
\hline The Cameraman & 1928 & Kameraman \\
\hline The Crowd & 1928 & Gomila \\
\hline Oktyabr & 1928 & Oktobar \\
\hline Steamboat Willie & 1928 & Parobrod Willy \\
\hline The Man Who Laughs & 1928 & Čovjek koji se smije \\
\hline Un chien andalou & 1929 & Andaluzijski pas \\
\hline Blackmail & 1929 & Ucjena \\
\hline The Broadway Melody & 1929 & Brodvejska melodija \\
\hline Queen Kelly & 1929 & Kraljica Kelly \\
\hline Big Business & 1929 & Veliki posao \\
\hline Chelovek s kino-apparatom & 1929 & Čovjek s filmskom kamerom \\
\hline Die Büchse der Pandora & 1929 & Pandorina kutija \\
\hline
\end{tabular}




\begin{tabular}{|c|c|c|}
\hline Tagebuch einer Verlorenen & 1929 & Dnevnik izgubljene \\
\hline L'âge d'or & 1930 & Zlatno doba \\
\hline À propos de Nice & 1930 & Povodom Nice \\
\hline Murder! & 1930 & Umorstvo \\
\hline The Big Trail & 1930 & Veliki put \\
\hline Morocco & 1930 & Maroko \\
\hline Zemlya & 1930 & Zemlja \\
\hline Der blaue Engel & 1930 & Plavi anđeo \\
\hline City Lights & 1931 & Svjetla velegrada \\
\hline The Public Enemy & 1931 & Državni neprijatelj \\
\hline Monkey Business & 1931 & Majmunska posla \\
\hline Little Caesar & 1931 & Mali Cezar \\
\hline Dracula & 1931 & Drakula \\
\hline Freaks & 1932 & Nakaze \\
\hline The Mummy & 1932 & Mumija \\
\hline Trouble in Paradise & 1932 & Nevolje u raju \\
\hline Horse Feathers & 1932 & Konjsko perje \\
\hline Vampyr & 1932 & Vampir \\
\hline Scarface & 1932 & Lice s ožiljkom \\
\hline I Am a Fugitive from a Chain Gang & 1932 & Ja sam bjegunac iz Chain ganga \\
\hline The Most Dangerous Game & 1932 & Najopasnija igra \\
\hline Duck Soup & 1933 & Pačja juha \\
\hline Sons of the Desert & 1933 & Sinovi pustinje \\
\hline Queen Christina & 1933 & Kraljica Kristina \\
\hline 42nd Street & 1933 & Četrdeset i druga ulica \\
\hline Das Testament des Dr. Mabuse & 1933 & Oporuka doktora Mabusea \\
\hline The Invisible Man & 1933 & Nevidljivi čovjek \\
\hline Dinner at Eight & 1933 & Večera u osam \\
\hline It Happened One Night & 1934 & Dogodilo se jedne noći \\
\hline The Man Who Knew Too Much & 1934 & Čovjek koji je previše znao \\
\hline The Black Cat & 1934 & Crna mačka \\
\hline The Gay Divorcee & 1934 & Vesela razvedenica \\
\hline
\end{tabular}




\begin{tabular}{|c|c|c|}
\hline Twentieth Century & 1934 & Dvadeseto stoljeće \\
\hline The Scarlet Empress & 1934 & Grimizna carica \\
\hline Bride of Frankenstein & 1935 & Frankensteinova nevjesta \\
\hline A Night at the Opera & 1935 & Noć u operi \\
\hline Top Hat & 1935 & Cilindar \\
\hline Triumph des Willens & 1935 & Trijumf volje \\
\hline The 39 Steps & 1935 & 39 stepenica \\
\hline Mutiny on the Bounty & 1935 & Pobuna u Bountyju \\
\hline Captain Blood & 1935 & Kapetan Blood \\
\hline The Informer & 1935 & Potkazivač \\
\hline A Tale of Two Cities & 1935 & Priča o dva grada \\
\hline Anna Karenina & 1935 & Ana Karenjina \\
\hline Modern Times & 1936 & Moderna vremena \\
\hline My Man Godfrey & 1936 & Moj čovjek Godfrey \\
\hline Mr. Deeds Goes to Town & 1936 & Gospodin Deeds ide u grad \\
\hline Sabotage & 1936 & Sabotaža \\
\hline The Petrified Forest & 1936 & Okamenjena šuma \\
\hline Swing Time & 1936 & Doba swinga \\
\hline Fury & 1936 & Bijes \\
\hline Reefer Madness & 1936 & Ludilo trave \\
\hline La grande illusion & 1937 & Velika iluzija \\
\hline The Awful Truth & 1937 & Strašna istina \\
\hline A Day at the Races & 1937 & Dan na utrkama \\
\hline Young and Innocent & 1937 & Mladi i nevini \\
\hline A Star Is Born & 1937 & Zvijezda je rođena \\
\hline Snow White and the Seven Dwarfs & 1937 & Snjeguljica i sedam patuljaka \\
\hline Lost Horizon & 1937 & Izgubljeni horizont \\
\hline Stage Door & 1937 & Ulaz na pozornicu \\
\hline Le quai des brumes & 1938 & Obala u magli \\
\hline The Adventures of Robin Hood & 1938 & Pustolovine Robina Hooda \\
\hline Holiday & 1938 & Praznik \\
\hline Angels with Dirty Faces & 1938 & Anđeli garava lica \\
\hline
\end{tabular}




\begin{tabular}{|c|c|c|}
\hline Mr. Smith Goes to Washington & 1939 & Gospodin Smith ide u Washington \\
\hline Stagecoach & 1939 & Poštanska kočija \\
\hline The Women & 1939 & Žene \\
\hline The Roaring Twenties & 1939 & Burne dvadesete \\
\hline Only Angels Have Wings & 1939 & Samo anđeli imaju krila \\
\hline The Wizard of Oz & 1939 & Čarobnjak iz Oza \\
\hline Wuthering Heights & 1939 & Orkanski visovi \\
\hline The Great Dictator & 1940 & Veliki diktator \\
\hline Fantasia & 1940 & Fantazija \\
\hline The Philadelphia Story & 1940 & Philadelphijska priča \\
\hline His Girl Friday & 1940 & Njegova djevojka Petko \\
\hline The Shop Around the Corner & 1940 & Trgovina iza ugla \\
\hline Foreign Correspondent & 1940 & Strani dopisnik \\
\hline The Thief of Bagdad & 1940 & Bagdadski lopov \\
\hline The Grapes of Wrath & 1940 & Plodovi gnjeva \\
\hline Citizen Kane & 1941 & Građanin Kane \\
\hline Suspicion & 1941 & Sumnja \\
\hline The Maltese Falcon & 1941 & Malteški sokol \\
\hline How Green Was My Valley & 1941 & Kako je bila zelena moja dolina \\
\hline Sergeant York & 1941 & Narednik York \\
\hline High Sierra & 1941 & Visoka Sierra \\
\hline To $\mathrm{Be}$ or Not to $\mathrm{Be}$ & 1942 & Biti ili ne biti \\
\hline Saboteur & 1942 & Saboter \\
\hline Cat People & 1942 & Ljudi mačke \\
\hline Mrs. Miniver & 1942 & Gospođa Miniver \\
\hline The Magnificent Ambersons & 1942 & Veličanstveni Ambersonovi \\
\hline Le corbeau & 1943 & Gavran \\
\hline Shadow of a Doubt & 1943 & Sjenka sumnje \\
\hline The Life and Death of Colonel Blimp & 1943 & Život i smrt pukovnika Blimpa \\
\hline Heaven Can Wait & 1943 & Nebo može čekati \\
\hline Vredens dag & 1943 & Dan gnjeva \\
\hline For Whom the Bell Tolls & 1943 & Kome zvono zvoni \\
\hline
\end{tabular}




\begin{tabular}{|c|c|c|}
\hline Sahara & 1943 & Sahara \\
\hline Arsenic and Old Lace & 1944 & Arsen i stare čipke \\
\hline Lifeboat & 1944 & Čamac za spašavanje \\
\hline The Three Caballeros & 1944 & Tri kabaljerosa \\
\hline To Have and Have Not & 1944 & Imati i nemati \\
\hline The Woman in the Window & 1944 & Žena u izlogu \\
\hline Les enfants du paradis & 1945 & Djeca raja \\
\hline Brief Encounter & 1945 & Kratak susret \\
\hline Roma città aperta & 1945 & Rim, otvoreni grad \\
\hline Scarlet Street & 1945 & Grimizna ulica \\
\hline The Lost Weekend & 1945 & Izgubljeni vikend \\
\hline Detour & 1945 & Zaobilaznica \\
\hline And Then There Were None & 1945 & I ne osta nijedan \\
\hline The Picture of Dorian Gray & 1945 & Slika Dorijana Grayja \\
\hline La belle et la bête & 1946 & Ljepotica i zvijer \\
\hline Notorious & 1946 & Ozloglašena \\
\hline The Best Years of Our Lives & 1946 & Najbolje godine našega života \\
\hline My Darling Clementine & 1946 & Moja draga Klementina \\
\hline The Big Sleep & 1946 & Duboki san \\
\hline Great Expectations & 1946 & Velika iščekivanja \\
\hline The Postman Always Rings Twice & 1946 & Poštar uvijek zvoni dvaput \\
\hline The Killers & 1946 & Ubojice \\
\hline Monsieur Verdoux & 1947 & Gospodin Verdoux \\
\hline Miracle on 34th Street & 1947 & Čudo u 34. ulici \\
\hline Out of the Past & 1947 & Iz prošlosti \\
\hline The Lady from Shanghai & 1947 & Dama iz Šangaja \\
\hline The Paradine Case & 1947 & Slučaj Paradine \\
\hline Black Narcissus & 1947 & Crni narcis \\
\hline Dark Passage & 1947 & Mračni prolaz \\
\hline The Ghost and Mrs. Muir & 1947 & Duh i gospođa Muir \\
\hline Gentlemen's Agreement & 1947 & Đentlmenski sporazum \\
\hline The Bishop's Wife & 1947 & Biskupova žena \\
\hline
\end{tabular}




\begin{tabular}{|c|c|c|}
\hline Rope & 1948 & Uže \\
\hline The Naked City & 1948 & Goli grad \\
\hline Ladri di biciclette & 1948 & Kradljivci bicikla \\
\hline Red River & 1948 & Crvena rijeka \\
\hline The Treasure of the Sierra Madre & 1948 & Blago Sierra Madre \\
\hline The Heiress & 1949 & Nasljednica \\
\hline The Third Man & 1949 & Treći čovjek \\
\hline Adam's Rib & 1949 & Adamovo rebro \\
\hline She Wore a Yellow Ribbon & 1949 & Nosila je žutu vrpcu \\
\hline Nora inu & 1949 & Pas lutalica \\
\hline All the King's Men & 1949 & Svi kraljevi ljudi \\
\hline All About Eve & 1950 & Sve o Evi \\
\hline Sunset Blvd. & 1950 & Bulevar sumraka \\
\hline The Asphalt Jungle & 1950 & Džungla na asfaltu \\
\hline In a Lonely Place & 1950 & Na osamljenom mjestu \\
\hline Los ovidados & 1950 & Zaboravljeni \\
\hline Cinderella & 1950 & Pepeljuga \\
\hline The Day the Earth Stood Still & 1951 & Dan kad je zemlja stala \\
\hline Ace in the Hole & 1951 & As u rukavu \\
\hline A Place in the Sun & 1951 & Mjesto pod suncem \\
\hline Alice in Wonderland & 1951 & Alisa u zemlji čudesa \\
\hline A Streetcar Named Desire & 1951 & Tramvaj zvan čežnja \\
\hline The African Queen & 1951 & Afrička kraljica \\
\hline Jeux interdits & 1952 & Zabranjene igre \\
\hline Limelight & 1952 & Svjetla pozornice \\
\hline Monkey Business & 1952 & Majmunska posla \\
\hline The Greatest Show on Earth & 1952 & Najveća predstava na svijetu \\
\hline Ikiru & 1952 & Živjeti \\
\hline High Noon & 1952 & Točno u podne \\
\hline The Quiet Man & 1952 & Miran čovjek \\
\hline Le salaire de la peur & 1953 & Nadnica za strah \\
\hline The Big Heat & 1953 & Velika žega \\
\hline
\end{tabular}




\begin{tabular}{|c|c|c|}
\hline Tôkyô monogatari & 1953 & Priča o Tokiju \\
\hline Gentlemen Prefer Blondes & 1953 & Muškarci više vole plavuše \\
\hline From Here to Eternity & 1953 & Odavde od vječnosti \\
\hline The War of the Worlds & 1953 & Rat svjetova \\
\hline Peter Pan & 1953 & Petar Pan \\
\hline White Christmas & 1954 & Bijeli Božić \\
\hline La strada & 1954 & Cesta \\
\hline Shichinin no samurai & 1954 & Sedam samuraja \\
\hline 20,000 Leagues Under the Sea & 1954 & 20000 milja pod morem \\
\hline Les diaboliques & 1955 & Demoni \\
\hline Lady and the Tramp & 1955 & Dama i skitnica \\
\hline Rebel Without a Cause & 1955 & Buntovnik bez razloga \\
\hline The Night of the Hunter & 1955 & Noć lovca \\
\hline East of Eden & 1955 & Istočno od raja \\
\hline The Trouble with Harry & 1955 & Nevolje s Harryjem \\
\hline The Ten Commandments & 1956 & Deset zapovijedi \\
\hline The Man Who Knew Too Much & 1956 & Čovjek koji je previše znao \\
\hline Forbidden Planet & 1956 & Zabranjen planet \\
\hline The King and I & 1956 & Kralj i ja \\
\hline The Searchers & 1956 & Tragači \\
\hline Invasion of the Body Snatchers & 1956 & Invazija tjelokradica \\
\hline Giant & 1956 & Div \\
\hline Sweet Smell of Success & 1957 & Slatki miris uspjeha \\
\hline Le notti di Cabiria & 1957 & Cabirijine noći \\
\hline 12 Angry Men & 1957 & 12 gnjevnih ljudi \\
\hline The Bridge on the River Kwai & 1957 & Most na rijeci Kwai \\
\hline Paths of Glory & 1957 & Staze slave \\
\hline Witness for the Prosecution & 1957 & Svjedok optužbe \\
\hline Det sjunde inseglet & 1957 & Sedmi pečat \\
\hline Mon oncle & 1958 & Moj ujak \\
\hline Ascenseur pour l'échafaud & 1958 & Lift za gubilište \\
\hline Touch of Evil & 1958 & Dodir zla \\
\hline
\end{tabular}




\begin{tabular}{|c|c|c|}
\hline Cat on a Hot Tin Roof & 1958 & Mačka na vrućem limenom krovu \\
\hline The Blob & 1958 & Gruda \\
\hline Horror of Dracula & 1958 & Strava Dracule \\
\hline Vertigo & 1958 & Vrtoglavica \\
\hline The Fly & 1958 & Muha \\
\hline Nort by Northwest & 1959 & Sjever-sjeverozapad \\
\hline Anatomy of a Murder & 1959 & Anatomija jednog ubojstva \\
\hline Some Like It Hot & 1959 & Neki to vole vruće \\
\hline Les quatre cents coups & 1959 & 400 udaraca \\
\hline Hiroshima mon amour & 1959 & Hirošima, ljubavi moja \\
\hline Plan 9 from Outer Space & 1959 & Plan 9 iz vanjskog svemira \\
\hline Sleeping Beauty & 1959 & Trnoružica \\
\hline The Apartment & 1960 & Apartman \\
\hline The Time Machine & 1960 & Vremenski stroj \\
\hline The Magnificent Seven & 1960 & Sedmorica veličanstvenih \\
\hline À bout de souffle & 1960 & Do posljednjeg daha \\
\hline La dolce vita & 1960 & Slatki život \\
\hline Peeping Tom & 1960 & Voajer \\
\hline Jungfrukällan & 1960 & Djevičanski izvor \\
\hline Psycho & 1960 & Psiho \\
\hline The Innocents & 1961 & Nevini \\
\hline Breakfast at Tiffany's & 1961 & Doručak kod Tiffanyja \\
\hline One Hundred and One Dalmatians & 1961 & 101 Dalmatinac \\
\hline The Guns of Navarone & 1961 & Topovi s Navaronea \\
\hline Judgment at Nuremberg & 1961 & Suđenje u Nürnbergu \\
\hline West Side Story & 1961 & Priča sa zapadne strane \\
\hline Yôjinbô & 1961 & Tjelesna straža \\
\hline The Hustler & 1961 & Hazarder \\
\hline To Kill a Mockingbird & 1962 & Ubiti pticu rugalicu \\
\hline The Manchurian Candidate & 1962 & Mandžurijski kandidat \\
\hline The Man Who Shot Liberty Valance & 1962 & Čovjek koji je ubio Liberty Valancea \\
\hline The Longest Day & 1962 & Najduži dan \\
\hline
\end{tabular}




\begin{tabular}{|c|c|c|}
\hline What Ever Happened to Baby Jane? & 1962 & Što se dogodilo s Baby Jane? \\
\hline Lawrence of Arabia & 1962 & Lawrence od Arabije \\
\hline Jules et Jim & 1962 & Jules i Jim \\
\hline La jetée & 1962 & Nasip \\
\hline The Great Escape & 1963 & Veliki bijeg \\
\hline From Russia with Love & 1963 & Iz Rusije s ljubavlju \\
\hline The Birds & 1963 & Ptice \\
\hline The Sword in the Stone & 1963 & Mač u kamenu \\
\hline Charade & 1963 & Šarada \\
\hline Otto e mezzo & 1963 & Osam i pol \\
\hline Cleopatra & 1963 & Kleopatra \\
\hline My Fair Lady & 1964 & Moja draga lady \\
\hline Per un pugno di dollari & 1964 & Za šaku dolara \\
\hline A Hard Day's Night & 1964 & Noć nakon teškog dana \\
\hline Rudolph, the Red-Nosed Reindeer & 1964 & Rudolf, sob crvenog nosa \\
\hline Pierrot le fou & 1965 & Ludi Pierrot \\
\hline Alphaville, une étrange aventure de Lemmy Caution & 1965 & Alphaville, neobična avantura Lemmyja Cautiona \\
\hline The Flight of the Phoenix & 1965 & Feniksov let \\
\hline Repulsion & 1965 & Odvratnost \\
\hline Per qualche dollaro in più & 1965 & Za dolar više \\
\hline A Charlie Brown Christmas & 1965 & Božić Charlieja Browna \\
\hline Help! & 1965 & U pomoć! \\
\hline Doctor Zhivago & 1965 & Doktor Živago \\
\hline Blowup & 1966 & Povećanje \\
\hline Who's Afraid of Virginia Woolf? & 1966 & Tko se boji Virginije Woolf ? \\
\hline How the Grinch Stole Christmas! & 1966 & Kako je Grinch ukrao Božić! \\
\hline A Man for All Seasons & 1966 & Čovjek za sva vremena \\
\hline Il buono, il brutto, il cattivo & 1966 & Dobar, loš, zao \\
\hline La battaglia di Algeri & 1966 & Bitka za Alžir \\
\hline The Graduate & 1967 & Diplomac \\
\hline The Producers & 1967 & Producenti \\
\hline In the Heat of the Night & 1967 & U vrelini noći \\
\hline
\end{tabular}




\begin{tabular}{|c|c|c|}
\hline You Only Live Twice & 1967 & Samo dvaput se živi \\
\hline Bonnie and Clyde & 1967 & Bonnie i Clyde \\
\hline The Jungle Book & 1967 & Knjiga o džungli \\
\hline 2001: A Space Odyssey & 1968 & 2001: Odiseja u svemiru \\
\hline Night of the Living Dead & 1968 & Noć živih mrtvaca \\
\hline Planet of the Apes & 1968 & Planet majmuna \\
\hline Rosemary's Baby & 1968 & Rosemaryna beba \\
\hline The Party & 1968 & Zabava \\
\hline C'era una volta il West & 1968 & Bilo jednom na Divljem zapadu \\
\hline The Wild Bunch & 1969 & Divlja horda \\
\hline L'armée des ombres & 1969 & Vojska sjena \\
\hline Take the Money and Run & 1969 & Uzmi novac i bježi \\
\hline Battle of Britain & 1969 & Bitka za Britaniju \\
\hline Midnight Cowboy & 1969 & Ponoćni kauboj \\
\hline Butch Cassidy and the Sundance Kid & 1969 & Butch Cassidy i Sundance Kid \\
\hline Beneath the Planet of the Apes & 1970 & Ispod planeta majmuna \\
\hline Five Easy Pieces & 1970 & Pet lakih komada \\
\hline Little Big Man & 1970 & Mali veliki čovjek \\
\hline Love Story & 1970 & Ljubavna priča \\
\hline Dirty Harry & 1971 & Prljavi Harry \\
\hline Duel & 1971 & Dvoboj \\
\hline The Last Picture Show & 1971 & Posljednja kino predstava \\
\hline Harold and Maude & 1971 & Harold i Maude \\
\hline Straw Dogs & 1971 & Psi od slame \\
\hline The French Connection & 1971 & Francuska veza \\
\hline The Godfather & 1972 & Kum \\
\hline Deliverance & 1972 & Oslobađanje \\
\hline Sleuth & 1972 & Njuškalo \\
\hline The Poseidon Adventure & 1972 & Posejdonova avantura \\
\hline Frenzy & 1972 & Mahnitost \\
\hline Ultimo tango a Parigi & 1972 & Posljednji tango u Parizu \\
\hline Aguirre, der Zorn Gottes & 1972 & Aguirre, gnjev božji \\
\hline
\end{tabular}




\begin{tabular}{|c|c|c|}
\hline The Exorcist & 1973 & Istjerivač đavola \\
\hline The Sting & 1973 & Žalac \\
\hline American Graffiti & 1973 & Američki grafiti \\
\hline The Wicker Man & 1973 & Čovjek od pruća \\
\hline Papillon & 1973 & Leptir \\
\hline Chinatown & 1974 & Kineska četvrt \\
\hline Young Frankenstein & 1974 & Mladi Frankenstein \\
\hline The Texas Chain Saw Massacre & 1974 & Teksaški masakr motornom pilom \\
\hline Blazing Saddles & 1974 & Vruća sedla \\
\hline Murder on the Orient Express & 1974 & Ubojstvo u Orient Expressu \\
\hline Death Wish & 1974 & Smrtonosna želja \\
\hline Jaws & 1975 & Ralje \\
\hline Monty Python and the Holy Grail & 1975 & Monty Python i Sveti gral \\
\hline Three Days of the Condor & 1975 & Tri dana Kondora \\
\hline Sholay & 1975 & Oganj \\
\hline Dog Day Afternoon & 1975 & Pasje poslijepodne \\
\hline Salò o le 120 giornate di Sodoma & 1975 & Salò, ili 120 dana Sodome \\
\hline Taxi Driver & 1976 & Taksist \\
\hline Network & 1976 & TV mreža \\
\hline The Omen & 1976 & Pretkazanje \\
\hline All the President's Men & 1976 & Svi predsjednikovi ljudi \\
\hline The Outlaw Josey Wales & 1976 & Odmetnik Josey Wales \\
\hline Marathon Man & 1976 & Maratonac \\
\hline Logan's Run & 1976 & Loganov bijeg \\
\hline The Enforcer & 1976 & Istjerivač pravde \\
\hline Close Encounters of the Third Kind & 1977 & Bliski susreti treće vrste \\
\hline Saturday Night Fever & 1977 & Groznica subotnje večeri \\
\hline The Rescuers & 1977 & Spasitelji \\
\hline Smokey and the Bandit & 1977 & Smokey i Bandit \\
\hline Star Wars & 1977 & Zvjezdani ratovi \\
\hline The Deer Hunter & 1978 & Lovac na jelene \\
\hline Grease & 1978 & Briljantin \\
\hline
\end{tabular}




\begin{tabular}{|c|c|c|}
\hline Halloween & 1978 & Noć vještica \\
\hline Animal House & 1978 & Zvjerinjak \\
\hline Midnight Express & 1978 & Ponoćni ekspres \\
\hline Jaws 2 & 1978 & Ralje 2 \\
\hline Invasion of the Body Snatchers & 1978 & Invazija tjelokradica \\
\hline Kramer vs. Kramer & 1979 & Kramer protiv Kramera \\
\hline Escape from Alcatraz & 1979 & Bijeg iz Alcatraza \\
\hline The Shining & 1980 & Isijavanje \\
\hline Raging Bull & 1980 & Razjareni bik \\
\hline The Elephant Man & 1980 & Čovjek slon \\
\hline The Blues Brothers & 1980 & Braća Blues \\
\hline Friday the 13 th & 1980 & Petak 13-ti \\
\hline The Blue Lagoon & 1980 & Plava laguna \\
\hline Escape from New York & 1981 & Bijeg iz New Yorka \\
\hline An American Werewolf in London & 1981 & Američki vukodlak u Londonu \\
\hline The Fox and the Hound & 1981 & Lisica i pas \\
\hline Halloween II & 1981 & Noć vještica 2 \\
\hline Conan the Barbarian & 1982 & Konan Barbarin \\
\hline The Thing & 1982 & Stvor \\
\hline Scarface & 1983 & Lice s ožiljkom \\
\hline A Christmas Story & 1983 & Božićna priča \\
\hline WarGames & 1983 & Ratne igre \\
\hline Videodrome & 1983 & Videodrom \\
\hline Risky Business & 1983 & Riskantan posao \\
\hline The Terminator & 1984 & Terminator \\
\hline Ghostbusters & 1984 & Istjerivači duhova \\
\hline A Nightmare on Elm Street & 1984 & Strava u ulici Brijestova \\
\hline Gremlins & 1984 & Gremlini \\
\hline Beverly Hills Cop & 1984 & Policajac s Beverly Hillsa \\
\hline This Is Spinal Tap & 1984 & Ovo je Spinal Tap \\
\hline Indiana Jones and the Temple of Doom & 1984 & Indiana Jones i ukleti hram \\
\hline Back to the Future & 1985 & Povratak u budućnost \\
\hline
\end{tabular}




\begin{tabular}{|c|c|c|}
\hline Commando & 1985 & Komandos \\
\hline Brazil & 1985 & Brazil \\
\hline Stand by $\mathrm{Me}$ & 1986 & Ostani uz mene \\
\hline Ferris Bueller's Day Off & 1986 & Slobodan dan Ferrisa Buellera \\
\hline Blue Velvet & 1986 & Plavi baršun \\
\hline The Fly & 1986 & Muha \\
\hline Highlander & 1986 & Gorštak \\
\hline Labyrinth & 1986 & Labirint \\
\hline The Princess Bride & 1987 & Kraljevna nevjesta \\
\hline The Untouchables & 1987 & Nedodirljivi \\
\hline Lethal Weapon & 1987 & Smrtonosno oružje \\
\hline Dirty Dancing & 1987 & Prljavi ples \\
\hline Spaceballs & 1987 & Svemirske lopte \\
\hline Predator & 1987 & Predator \\
\hline Rain Man & 1988 & Kišni čovjek \\
\hline Who Framed Roger Rabbit & 1988 & Tko je smjestio zeki Rogeru? \\
\hline Nuovo Cinema Paradiso & 1988 & Novo kino Raj \\
\hline Tonari no Totoro & 1988 & Moj susjed Totoro \\
\hline Hotaru no haka & 1988 & Groblje krijesnica \\
\hline Indiana Jones and the Last Crusade & 1989 & Indiana Jones i Posljednji križarski pohod \\
\hline Dead Poets Society & 1989 & Društvo mrtvih pjesnika \\
\hline The Little Mermaid & 1989 & Mala sirena \\
\hline When Harry Met Sally... & 1989 & Kad je Harry sreo Sally \\
\hline Ghostbusters II & 1989 & Istjerivači duhova 2 \\
\hline The Abyss & 1989 & Bezdan \\
\hline Lethal Weapon 2 & 1989 & Smrtonosno oružje 2 \\
\hline Honey, I Shrunk the Kids & 1989 & Draga, smanjio sam djecu \\
\hline Goodfellas & 1990 & Dobri momci \\
\hline Edward Scissorhands & 1990 & Edward Škaroruki \\
\hline Home Alone & 1990 & Sam u kući \\
\hline Total Recall & 1990 & Totalni opoziv \\
\hline Pretty Woman & 1990 & Zgodna žena \\
\hline
\end{tabular}




\begin{tabular}{|c|c|c|}
\hline Ghost & 1990 & Duh \\
\hline Terminator 2: Judgment Day & 1991 & Terminator 2: Sudnji dan \\
\hline Thelma \& Louise & 1991 & Thelma i Louise \\
\hline Beauty and the Beast & 1991 & Ljepotica i zvijer \\
\hline Robin Hood: Prince of Thieves & 1991 & Robin Hood: Princ lopova \\
\hline The Addams Family & 1991 & Obitelj Adams \\
\hline Reservoir Dogs & 1992 & Psi iz rezervoara \\
\hline Batman Returns & 1992 & Batman se vraća \\
\hline Scent of a Woman & 1992 & Miris žene \\
\hline A Few Good Men & 1992 & Malo dobrih ljudi \\
\hline Dracula & 1992 & Drakula \\
\hline What's Eating Gilbert Grape & 1993 & Što muči Gilberta Grapea \\
\hline Schindler's List & 1993 & Schindlerova lista \\
\hline Jurassic Park & 1993 & Jurski park \\
\hline The Fugitive & 1993 & Bjegunac \\
\hline True Romance & 1993 & Prava romansa \\
\hline Dumb \& Dumber & 1994 & Glup i gluplji \\
\hline The Mask & 1994 & Maska \\
\hline Speed & 1994 & Brzina \\
\hline The Shawshank Redemption & 1994 & Iskupljenje u Shawshanku \\
\hline Braveheart & 1995 & Hrabro srce \\
\hline Toy Story & 1995 & Priča o igračkama \\
\hline Twelve Monkeys & 1995 & 12 majmuna \\
\hline Heat & 1995 & Vrućina \\
\hline Casino & 1995 & Kasino \\
\hline Se7en & 1995 & Sedam \\
\hline Independence Day & 1996 & Dan nezavisnosti \\
\hline The Rock & 1996 & Hrid \\
\hline Scream & 1996 & Vrisak \\
\hline From Dusk Till Dawn & 1996 & Od sumraka do zore \\
\hline Mars Attacks! & 1996 & Mars napada \\
\hline Good Will Hunting & 1997 & Dobri Will Hunting \\
\hline
\end{tabular}




\begin{tabular}{|c|c|c|}
\hline L.A. Confidential & 1997 & L.A. povjerljivo \\
\hline Le cinquième élément & 1997 & Peti element \\
\hline The Game & 1997 & Igra \\
\hline The Devil's Advocate & 1997 & Đavolji odvjetnik \\
\hline La vita è bella & 1997 & Život je lijep \\
\hline Saving Private Ryan & 1998 & Spašavanje vojnika Ryana \\
\hline The Truman Show & 1998 & Trumanov šou \\
\hline The Big Lebowski & 1998 & Veliki Lebowski \\
\hline Fear and Loathing in Las Vegas & 1998 & Strah i prezir u Las Vegasu \\
\hline The Green Mile & 1999 & Zelena milja \\
\hline The Sixth Sense & 1999 & Šesto čulo \\
\hline Star Wars: Episode I - The Phantom Menace & 1999 & Zvjezdani ratovi Epizoda 1: Fantomska prijetnja \\
\hline Toy Story 2 & 1999 & Priča o igračkama 2 \\
\hline The Mummy & 1999 & Mumija \\
\hline American Pie & 1999 & Američka pita \\
\hline Sleepy Hollow & 1999 & Sanjiva dolina \\
\hline Gladiator & 2000 & Gladijator \\
\hline American Psycho & 2000 & Američki psiho \\
\hline Le fabuleux destin d'Amélie Poulain & 2001 & Čudesna sudbina Amélie Poulain \\
\hline Ocean's Eleven & 2001 & Oceanovih jedanaest \\
\hline Training Day & 2001 & Dan obuke \\
\hline The Lord of the Rings: The Fellowship of the Ring & 2001 & Gospodar prstenova: Prstenova družina \\
\hline Catch Me If You Can & 2002 & Uhvati me ako možeš \\
\hline The Pianist & 2002 & Pijanist \\
\hline The Bourne Identity & 2002 & Bourneov identitet \\
\hline Ice Age & 2002 & Ledeno doba \\
\hline Cidade de Deus & 2002 & Božji grad \\
\hline The Lord of the Rings: The Two Towers & 2002 & Gospodar prstenova: Dvije kule \\
\hline Harry Potter and the Chamber of Secrets & 2002 & Harry Potter i Odaja tajni \\
\hline Mystic River & 2003 & Mistična rijeka \\
\hline Pirates of the Caribbean: The Curse of the Black Pearl & 2003 & Pirati s Kariba: Prokletstvo crnog bisera \\
\hline Big Fish & 2003 & Krupna riba \\
\hline
\end{tabular}




\begin{tabular}{|c|c|c|}
\hline The Lord of the Rings: The Return of the King & 2003 & Gospodar prstenova: Povratak kralja \\
\hline Troy & 2004 & Troja \\
\hline I, Robot & 2004 & Ja, robot \\
\hline Harry Potter and the Prisoner of Azkaban & 2004 & Harry Potter i Zatočenik Azkabana \\
\hline Star Wars: Episode III - Revenge of the Sith & 2005 & Ratovi zvijezda: Epizoda III - Osveta Sitha \\
\hline Mr. \& Mrs. Smith & 2005 & Gospodin i gospođa Smith \\
\hline War of the Worlds & 2005 & Rat svjetova \\
\hline Charlie and the Chocolate Factory & 2005 & Charlie i tvornica čokolade \\
\hline V for Vendetta & 2005 & O za osvetu \\
\hline Harry Potter and the Goblet of Fire & 2005 & Harry Potter i Plameni pehar \\
\hline The Departed & 2006 & Pokojni \\
\hline Pirates of the Caribbean: Dead Man's Chest & 2006 & Pirati s Kariba: Mrtvačeva škrinja \\
\hline Blood Diamond & 2006 & Krvavi dijamant \\
\hline The Prestige & 2006 & Prestiž \\
\hline El laberinto del fauno & 2006 & Panov labirint \\
\hline I Am Legend & 2007 & Ja sam legenda \\
\hline Transformers & 2007 & Transformeri \\
\hline The Bourne Ultimatum & 2007 & Bourneov ultimatum \\
\hline Pirates of the Caribbean: At World's End & 2007 & Pirati s Kariba: Na kraju svijeta \\
\hline No Country for Old Men & 2007 & Nema zemlje za starce \\
\hline Twilight & 2008 & Sumrak \\
\hline Indiana Jones and the Kingdom of the Crystall Skull & 2008 & Indiana Jones i Kraljevstvo kristalne lubanje \\
\hline The Curious Case of Benjamin Button & 2008 & Neobična priča o Benjaminu Buttonu \\
\hline The Hangover & 2009 & Mamurluk \\
\hline The District 9 & 2009 & Distrikt 9 \\
\hline Watchmen & 2009 & Čuvari \\
\hline Avatar & 2009 & Avatar \\
\hline Inception & 2010 & Početak \\
\hline Shutter Island & 2010 & Otok Shutter \\
\hline Black Swan & 2010 & Crni labud \\
\hline Toy Story 3 & 2010 & Priča o igračkama 3 \\
\hline The King's Speech & 2010 & Kraljev govor \\
\hline
\end{tabular}




\begin{tabular}{|c|c|c|}
\hline How to Train Your Dragon & 2010 & Kako izdresirati zmaja \\
\hline The Social Network & 2010 & Društvena mreža \\
\hline Captain America: The First Avenger & 2011 & Kapetan Amerika: Prvi osvetnik \\
\hline Intouchables & 2011 & Nedodirljivi \\
\hline Drive & 2011 & Vožnja \\
\hline Source Code & 2011 & Izvorni kod \\
\hline Harry Potter and the Deathly Hallows: Part 2 & 2011 & Harry Potter i Darovi smrti 2. dio \\
\hline The Avengers & 2012 & Osvetnici \\
\hline Prometheus & 2012 & Prometej \\
\hline The Hobbit: An Unexpected Journey & 2012 & Hobit: Neočekivano putovanje \\
\hline The Hunger Games & 2012 & Igre gladi \\
\hline Gravity & 2013 & Gravitacija \\
\hline Man of Steel & 2013 & Čovjek od čelika \\
\hline The Wolf of Wall Street & 2013 & Vuk s Wall Streeta \\
\hline World War Z & 2013 & Svjetski rat Z \\
\hline The Hobbit: The Desolation of Smaug & 2013 & Hobit: Smaugova pustoš \\
\hline Guardians of the Galaxy & 2014 & Čuvari galaksije \\
\hline Gone Girl & 2014 & Nestala \\
\hline Captain America: The Winter Soldier & 2014 & Kapetan Amerika: Ratnik zime \\
\hline The Grand Budapest Hotel & 2014 & Hotel Grand Budapest \\
\hline The Imitation Game & 2014 & Igra oponašanja \\
\hline Kingsman: The Secret Service & 2014 & Kingsman: Tajna služba \\
\hline Mad Max: Fury Road & 2015 & Pobješnjeli Max: Divlja cesta \\
\hline The Martian & 2015 & Marsovac \\
\hline The Revenant & 2015 & Povratnik \\
\hline Jurassic World & 2015 & Jurski svijet \\
\hline The Hateful Eight & 2015 & Mrska osmorka \\
\hline Inside Out & 2015 & Izvrnuto obrnuto \\
\hline Captain America: Civil War & 2016 & Kapetan Amerika: Građanski rat \\
\hline Arrival & 2016 & Dolazak \\
\hline Doctor Strange & 2016 & Doktor Strange \\
\hline Spider-Man: Homecoming & 2017 & Spider-Man: Povratak kući \\
\hline
\end{tabular}




\begin{tabular}{|l|l|l|}
\hline Get Out & 2017 & Bježi! \\
\hline Beauty and the Beast & 2017 & Ljepotica i zvijer \\
\hline It & 2017 & Ono \\
\hline
\end{tabular}

\subsection{Free translation}

\begin{tabular}{|l|c|l|}
\hline A Woman of Paris: A Drama of Fate & 1923 & Parižanka \\
\hline Three Ages & 1923 & Tri povijesna doba \\
\hline The Hunchback of Notre Dame & 1923 & Zvonar crkve Notre Dame \\
\hline Die Nibelungen: Siegfried & 1924 & Nibelunzi: Siegfridova smrt \\
\hline He Who Gets Slapped & 1924 & Onaj kojega su tresnuli \\
\hline Seven Chances & 1925 & Sedam sreća \\
\hline Go West & 1925 & Na zapad \\
\hline Faust: Eine deutsche Volkssage & 1926 & Faust \\
\hline The Unknown & 1927 & Nepoznati \\
\hline Sunrise: A Song of Two Humans & 1927 & Izlazak sunca - Pjesma o dva ljudska bića \\
\hline La passion de Jeanne d'Arc & 1928 & Stradanje Ivane Orleanske \\
\hline All Quiet on the Western Front & 1930 & Na zapadu ništa novo \\
\hline Hell's Angels & 1930 & Pakleni anđeli \\
\hline Of Human Bondage & 1934 & Ljudski okovi \\
\hline The Thin Man & 1934 & Mršavko \\
\hline After the Thin Man & 1936 & Nakon Mršavka \\
\hline Way Out West & 1937 & Stanlio i Olio na Divljem zapadu \\
\hline Captains Courageous & 1937 & Kapetan Hrabrosti \\
\hline You Can't Take It with You & 1938 & U grob ništa ne nosiš \\
\hline The Lady Vanishes & 1938 & Dama koja nestaje \\
\hline La règle du jeu & 1939 & Pravila igre \\
\hline Gone with the Wind & 1939 & Zameo ih vjetar \\
\hline The Wolf Man & 1941 & Vukodlak \\
\hline Sullivan's Travels & 1941 & Sullivanovo putovanje \\
\hline & & \\
\hline
\end{tabular}




\begin{tabular}{|c|c|c|}
\hline I Walked with a Zombie & 1943 & Šetala sam se uz zombija \\
\hline Double Indemnity & 1944 & Dvostruka obmana \\
\hline Meet Me in St. Louis & 1944 & Srest ćemo se u St. Louisu \\
\hline Spellbound & 1945 & Začarana \\
\hline It's a Wonderful Life & 1946 & Divan život \\
\hline Key Largo & 1948 & Otok Largo \\
\hline Fort Apache & 1948 & Na apaškoj granici \\
\hline Bud Abbott and Lou Costello Meet Frankenstein & 1948 & Abbott i Costello susreću Frankensteina \\
\hline The Red Shoes & 1948 & Crvene cipelice \\
\hline Kind Hearts and Coronets & 1949 & Nježno srce \\
\hline The Thing from Another World & 1951 & Stvar \\
\hline Strangers on a Train & 1951 & Nepoznati iz Nord Expressa \\
\hline Singin' in the Rain & 1952 & Pjevajmo na kiši \\
\hline Roman Holiday & 1953 & Praznik u Rimu \\
\hline The Caine Mutiny & 1954 & Pobuna na brodu Caine \\
\hline Rear Window & 1954 & Prozor u dvorište \\
\hline On the Waterfront & 1954 & Na dokovima New Yorka \\
\hline Dial M for Murder & 1954 & Nazovi M radi ubojstva \\
\hline Du rififi chez les hommes & 1955 & Obračun među gangsterima \\
\hline The Seven Year Itch & 1955 & Sedma godina vjernosti \\
\hline To Catch a Thief & 1955 & Uhvatite Iopova \\
\hline Around the World in Eighty Days & 1956 & Put oko svijeta za 80 dana \\
\hline Smultronstället & 1957 & Divlje jagode \\
\hline An Affair to Remember & 1957 & Nešto za sjećanje \\
\hline House on Haunted Hill & 1959 & Kuća straha \\
\hline It's a Mad Mad Mad Mad World & 1963 & Svijet je poludio \\
\hline A Shot in the Dark & 1964 & Pink Panther: Pucanj u tami \\
\hline $\begin{array}{l}\text { Dr. Strangelove or: How I Learned to Stop Worrying and } \\
\text { Love the Bomb }\end{array}$ & 1964 & $\begin{array}{l}\text { Dr. Strangelove ili: Kako sam naučio ne brinuti i zavolio } \\
\text { bombu }\end{array}$ \\
\hline Thunderball & 1965 & Operacija Grom \\
\hline The Dirty Dozen & 1967 & 12 žigosanih \\
\hline Hang 'Em High & 1968 & Objesite ga bez milosti \\
\hline
\end{tabular}




\begin{tabular}{|c|c|c|}
\hline On Her Majesty's Secret Service & 1969 & U službi njenog veličanstva \\
\hline The AristoCats & 1970 & Mačke iz visokog društva \\
\hline A Clockwork Orange & 1971 & Paklena naranča \\
\hline Willy Wonka \& the Chocolate Factory & 1971 & Charlie i tvornica čokolade \\
\hline Diamonds are Forever & 1971 & Dijamanti su vječni \\
\hline $\begin{array}{l}\text { Everything You Always Wanted to Know About Sex * But } \\
\text { Were Afraid to Ask }\end{array}$ & 1972 & Sve što ste željeli znati o seksu \\
\hline Live and Let Die & 1973 & James Bond: Živi i pusti umrijeti \\
\hline Enter the Dragon & 1973 & U zmajevom gnijezdu \\
\hline Mean Streets & 1973 & Ulice nasilja \\
\hline The Godfather: Part II & 1974 & Kum 2 \\
\hline The Man with the Golden Gun & 1974 & James Bond 007: Čovjek sa zlatnim pištoljem \\
\hline The Towering Inferno & 1974 & Pakleni toranj \\
\hline One Flew Over the Cuckoo's Nest & 1975 & Let iznad kukavičjeg gnijezda \\
\hline The Man Who Would Be King & 1975 & Čovjek koji je htio biti kralj \\
\hline The Spy Who Loved Me & 1977 & James Bond 007: Špijun koji me volio \\
\hline A Bridge Too Far & 1977 & Nedostižni most \\
\hline Dawn of the Dead & 1978 & Zora živih mrtvaca \\
\hline Days of Heaven & 1978 & Nebeski dani \\
\hline The Warriors & 1979 & Ratnici podzemlja \\
\hline Life of Brian & 1979 & Brianov život \\
\hline Apocalypse Now & 1979 & Apokalipsa danas \\
\hline Mad Max & 1979 & Pobješnjeli Max \\
\hline Star Wars: Episode V - The Empire Strikes Back & 1980 & Zvjezdani ratovi V: Carstvo uzvraća udarac \\
\hline Airplane! & 1980 & Ima li pilota u avionu \\
\hline For Your Eyes Only & 1981 & James Bond 007: Samo za tvoje oči \\
\hline Raiders of the Lost Ark & 1981 & Indiana Jones: Otimači izgubljenog kovčega \\
\hline Das Boot & 1981 & Podmornica \\
\hline The Evil Dead & 1981 & Zla smrt \\
\hline Mad Max 2 & 1981 & Pobješnjeli Max 2 \\
\hline Star Trek: The Wrath of Khan & 1982 & Zvjezdane staze II: Khanov bijes \\
\hline Star Wars: Episode VI - Return of the Jedi & 1983 & Zvjezdani ratovi VI: Povratak Jedija \\
\hline
\end{tabular}




\begin{tabular}{|c|c|c|}
\hline The Meaning of Life & 1983 & Monty Python: Smisao života \\
\hline National Lampoon's Vacation & 1983 & Godišnji odmor snova \\
\hline Mad Max Beyond Thunderdome & 1985 & Pobješnjeli Max 3 \\
\hline The Breakfast Club & 1985 & Klub ranoranilaca \\
\hline A View to Kill & 1985 & Pogled na ubojstvo \\
\hline Platoon & 1986 & Vod smrti \\
\hline Evil Dead II & 1987 & Zla smrt II \\
\hline Coming to America & 1988 & Princ otkriva Ameriku \\
\hline The Naked Gun: From the Files of Police Squad! & 1988 & Goli pištolj \\
\hline Big & 1988 & Veliki \\
\hline Back to the Future Part II & 1989 & Povratak u budućnost II \\
\hline Back to the Future Part III & 1990 & Povratak u budućnost III \\
\hline The Godfather: Part III & 1990 & Kum 3 \\
\hline Dances with Wolves & 1990 & Ples s vukovima \\
\hline Edward Scissorhands & 1990 & Edward Škaroruki \\
\hline Hook & 1991 & Kapetan Kuka \\
\hline The Silence of the Lambs & 1991 & Kad jaganjci utihnu \\
\hline Cape Fear & 1991 & Rt straha \\
\hline Home Alone 2: Lost in New York & 1992 & Sam u kući 2 \\
\hline Groundhog Day & 1993 & Beskrajni dan \\
\hline The Nightmare Before Christmas & 1993 & Predbožićna noćna mora \\
\hline Interview with the Vampire: The Vampire Chronicles & 1994 & Intervju s vampirom \\
\hline Léon & 1994 & Leon profesionalac \\
\hline Pulp Fiction & 1994 & Pakleni šund \\
\hline Ace Ventura: Pet Detective & 1994 & Ace Ventura: Šašavi detektiv \\
\hline The Lion King & 1994 & Kralj lavova \\
\hline The Usual Suspects & 1995 & Privedite osumnjičene \\
\hline Die Hard with a Vengeance & 1995 & Umri muški 3 \\
\hline Mission: Impossible & 1996 & Nemoguća misija \\
\hline Romeo + Juliet & 1996 & Romeo i Julija \\
\hline The Lost World: Jurassic Park & 1997 & Jurski park 2: Izgubljeni svijet \\
\hline Men in Black & 1997 & Ljudi u crnom \\
\hline
\end{tabular}




\begin{tabular}{|c|c|c|}
\hline There's Something About Mary & 1998 & Svi su ludi za Mary \\
\hline A Bug's Life & 1998 & Život buba \\
\hline Fight Club & 1999 & Klub boraca \\
\hline Snatch & 2000 & Zdrpi i briši \\
\hline Requiem for a Dream & 2000 & Rekvijem za snove \\
\hline Unbreakable & 2000 & Neslomljivi \\
\hline Mission: Impossible II & 2000 & Nemoguća misija 2 \\
\hline A Beautiful Mind & 2001 & Genijalni um \\
\hline Monsters, Inc. & 2001 & Čudovišta iz ormara \\
\hline Harry Potter and the Sorcerer's Stone & 2001 & Harry Potter i kamen mudraca \\
\hline Minority Report & 2002 & Specijalni izvještaj \\
\hline Star Wars: Episode II - Attack of the Clones & 2002 & Zvjezdani ratovi Epizoda II: Klonovi napadaju \\
\hline Finding Nemo & 2003 & Potraga za Nemom \\
\hline Eternal Sunshine of the Spotless Mind & 2004 & Vječni sjaj nepobjedivog uma \\
\hline Million Dollar Baby & 2004 & Djevojka od milijun dolara \\
\hline Batman Begins & 2005 & Batman: Početak \\
\hline The 40 Year Old Virgin & 2005 & Junfer u četrdesetoj \\
\hline Little Miss Sunshine & 2006 & Mala miss Amerike \\
\hline Children of Men & 2006 & Djeca čovječanstva \\
\hline Into the Wild & 2007 & U divljini \\
\hline Slumdog Millionaire & 2008 & Milijunaš s ulice \\
\hline The Dark Knight & 2008 & Vitez tame \\
\hline Zombieland & 2009 & Dobrodošli u zemlju zombija \\
\hline Inglourious Basterds & 2009 & Nemilosrdni gadovi \\
\hline (500) Days of Summer & 2009 & (500) dana ljubavi \\
\hline Star Trek & 2009 & Zvjezdane staze \\
\hline Rise of the Planet of the Apes & 2011 & Planet majmuna: Postanak \\
\hline The Hangover Part II & 2011 & Mamurluk 2 \\
\hline X: First Class & 2011 & X-Men: Prva generacija \\
\hline The Dark Knight Rises & 2012 & Vitez tame: Povratak \\
\hline Django Unchained & 2012 & Odbjegli Django \\
\hline The Hunger Games: Catching Fire & 2013 & Igre gladi: Plamen \\
\hline
\end{tabular}




\begin{tabular}{|c|c|c|}
\hline 12 Years a Slave & 2013 & 12 godina ropstva \\
\hline Edge of Tomorrow & 2014 & Na rubu budućnosti \\
\hline Gone Girl & 2014 & Nestala \\
\hline Star Wars: Episode VII - The Force Awakens & 2015 & Ratovi zvijezda: Sila se budi \\
\hline Avengers: Age of Ultron & 2015 & Osvetnici 2: Vladavina Ultrona \\
\hline Zootopia & 2016 & Zootropola \\
\hline Baby Driver & 2017 & Vozač \\
\hline
\end{tabular}

\subsection{Transcreation}

\begin{tabular}{|l|c|l|}
\hline Safety Last! & 1923 & Napokon spas! \\
\hline Battling Butler & 1926 & Buster, boksački šampion \\
\hline The Cocoanuts & 1929 & Braća Marx: Tvrde glave \\
\hline Animal Crackers & 1930 & Krotitelji \\
\hline Gold Diggers of 1933 & 1933 & Lov na sreću \\
\hline Bringing Up Baby & 1938 & Silom dadilja \\
\hline Now, Voyager & 1942 & Na raskršću \\
\hline The Ox-Bow Incident & 1943 & Omča za vješanje \\
\hline Murder, My Sweet & 1944 & Zbogom ljepotice \\
\hline White Heat & 1949 & Usijanje \\
\hline Twelve O'Clock High & 1949 & Polijetanje usred dana \\
\hline Scrooge & 1951 & Božićna priča \\
\hline The Bad and the Beautiful & 1952 & Grad iluzija \\
\hline The Ladykillers & 1955 & Gangsterska petorka \\
\hline The Killing & 1956 & Uzaludna pljačka \\
\hline The Wrong Man & 1956 & Krivo optužen \\
\hline Kumonosu-jô & 1957 & Krvavo prijestolje \\
\hline Săsom i en spegel & 1961 & Kroz tamno ogledalo \\
\hline The Haunting & 1963 & Kuća duhova \\
\hline The Sound of Music & 1965 & Moje pjesme, moji snovi \\
\hline
\end{tabular}




\begin{tabular}{|l|l|l|}
\hline Cool Hand Luke & 1967 & Hladnokrvni kažnjenik \\
\hline Where Eagle Dares & 1968 & Orlovo gnijezdo \\
\hline Easy Rider & 1969 & Goli u sedlu \\
\hline True Gift & 1969 & Čovjek zvan Hrabrost \\
\hline Kelly's Heroes & 1970 & Zlato za odvažne \\
\hline The Conversation & 1974 & Prisluškivanje \\
\hline Moonraker & 1979 & James Bond 007: Operacija Svemir \\
\hline Caddyshack & 1980 & Golf klub \\
\hline Stripes & 1981 & Vojničine \\
\hline Blade Runner & 1982 & Istrebljivač \\
\hline First Blood & 1982 & Rambo \\
\hline Trading Places & 1983 & Kolo sreće \\
\hline Aliens & 1986 & Alien 2 \\
\hline Die Hard & 1988 & Umri muški \\
\hline Beetlejuice & 1988 & Bubimir \\
\hline Die Hard 2 & 1990 & Umri muški 2 \\
\hline Point Break & 1991 & Pakleni val \\
\hline Unforgiven & 1992 & Nepomirljivi \\
\hline Basic Instinct & 1992 & Sirove strasti \\
\hline Mrs. Doubtfire & 1993 & Tatica u suknji \\
\hline Clerks & 1993 & Trgovci \\
\hline Face/Off & 1997 & Čovjek bez lica \\
\hline American History X & 1998 & Generacija X \\
\hline Lock, Stock and the Two Smoking Barrels & 1998 & Lopovi, ubojice i dvije nabijene puške \\
\hline American Beauty & 1999 & Vrtlog života \\
\hline Cast Away & 2000 & Brodolom života \\
\hline Meet the Parents & 2000 & Dozvola za brak \\
\hline Sen to Chihiro no kamikakushi & 2001 & Avanture male Chihiro \\
\hline Oldeuboi & 2003 & Oldboy \\
\hline The Incredibles & 2004 & Izbavitelji \\
\hline The Notebook & 2004 & Zima za dvoje \\
\hline Shaun of the Dead & 2004 & Noć glupih mrtvaca \\
\hline & & \\
\hline
\end{tabular}




\begin{tabular}{|l|l|l|}
\hline Ratatouille & 2007 & Juhu-hu \\
\hline Taken & 2008 & 96 sati \\
\hline Up & 2009 & Nebesa \\
\hline Despicable Me & 2010 & Kako je Gru ukrao mjesec \\
\hline Limitless & 2011 & Savršena formula \\
\hline Silver Linings Playbook & 2012 & U dobru i u zlu \\
\hline Now You See Me & 2013 & Majstori iluzije \\
\hline Frozen & 2013 & Snježno kraljevstvo \\
\hline Whiplash & 2014 & Ritam ludila \\
\hline Suicide Squad & 2016 & Odred otpisanih \\
\hline
\end{tabular}

\subsection{Transcription}

\begin{tabular}{|l|c|l|}
\hline Sherlock Jr. & 1924 & Sherlock Jr. \\
\hline Metropolis & 1927 & Metropolis \\
\hline Cimarron & 1931 & Cimarron \\
\hline Frankenstein & 1931 & Frankenstein \\
\hline M & 1931 & M \\
\hline Tabu: A Story of the South Seas & 1931 & Tabu \\
\hline Grand Hotel & 1932 & Grand Hotel \\
\hline King Kong & 1933 & King Kong \\
\hline Dodsworth & 1936 & Dodsworth \\
\hline Jezebel & 1938 & Jezebel \\
\hline Aleksandr Nevskiy & 1938 & Alexander Nevsky \\
\hline Pygmalion & 1938 & Pygmalion \\
\hline Ninotchka & 1939 & Ninočka \\
\hline Pinocchio & 1940 & Pinocchio \\
\hline Rebecca & 1940 & Rebecca \\
\hline Dumbo & 1941 & Dumbo \\
\hline The Lady Eve & 1941 & Lady Eve \\
\hline
\end{tabular}




\begin{tabular}{|l|l|l|}
\hline Yankee Doodle Dandy & 1942 & Yankee Doodle Dandy \\
\hline Casablanca & 1942 & Casablanca \\
\hline Bambi & 1942 & Bambi \\
\hline Holiday Inn & 1942 & Holiday Inn \\
\hline Jane Eyre & 1943 & Jane Eyre \\
\hline Laura & 1944 & Laura \\
\hline Mildred Pierce & 1945 & Mildred Pierce \\
\hline Gilda & 1947 & Gilda \\
\hline Hamlet & 1948 & Hamlet \\
\hline Winchester '73 & 1950 & Winchester '73 \\
\hline Rio Grande & 1950 & Rio Grande \\
\hline Rashômon & 1950 & Rašomon \\
\hline Umberto D. & 1952 & Umberto D \\
\hline Stalag 17 & 1953 & Stalag 17 \\
\hline Shane & 1953 & Shane \\
\hline Sabrina & 1954 & Sabrina \\
\hline Gojira & 1954 & Godzilla \\
\hline Gigi & 1958 & Gigi \\
\hline Ben-Hur & 1959 & Ben-Hur \\
\hline Rio Bravo & 1959 & Rio Bravo \\
\hline Spartacus & 1960 & Spartak \\
\hline Viridiana & 1961 & Viridiana \\
\hline Dr. No & 1962 & Dr. No \\
\hline Lolita & 1962 & Lolita \\
\hline The Pink Panther & 1963 & Pink Panther \\
\hline Goldfinger & 1964 & Goldfinger \\
\hline Mary Poppins & 1964 & Mary Poppins \\
\hline Marnie & 1964 & Marnie \\
\hline Zulu & 1964 & Zulu \\
\hline Persona & 1966 & Persona \\
\hline Fahrenheit 451 & 1966 & Fahrenheit 451 \\
\hline Andrey Rublev & 1966 & Andrej Rubljov \\
\hline & & \\
\hline
\end{tabular}




\begin{tabular}{|l|l|l|}
\hline Chitty Chitty Bang Bang & 1968 & Chitty Chitty Bang Bang \\
\hline Bullitt & 1968 & Bullitt \\
\hline Z & 1969 & Z \\
\hline MASH & 1970 & M.A.S.H. \\
\hline Patton & 1970 & Patton \\
\hline Tora! Tora! Tora! & 1970 & Tora! Tora! Tora! \\
\hline THX 1138 & 1971 & THX 1138 \\
\hline Cabaret & 1972 & Cabaret \\
\hline Solyaris & 1972 & Solaris \\
\hline Robin Hood & 1973 & Robin Hood \\
\hline Serpico & 1973 & Serpico \\
\hline Barry Lyndon & 1975 & Barry Lyndon \\
\hline The Rocky Horror Picture Show & 1975 & Rocky Horror Picture Show \\
\hline Rocky & 1976 & Rocky \\
\hline Carrie & 1976 & Carrie \\
\hline Annie Hall & 1977 & Annie Hall \\
\hline Eraserhead & 1977 & Eraserhead \\
\hline Suspiria & 1977 & Suspiria \\
\hline Superman & 1978 & Superman \\
\hline Rocky II & 1979 & Rocky 2 \\
\hline Manhattan & 1979 & Manhattan \\
\hline Alien & 1979 & Alien: Osmi putnik \\
\hline Superman II & 1980 & Superman 2 \\
\hline Poltergeist & 1982 & Poltergeist \\
\hline TRON & 1982 & Tron \\
\hline Gandhi & 1982 & Gandhi \\
\hline Rocky III & 1982 & Rocky 3 \\
\hline E.T. the Extra-Terrestrial & 1982 & E.T. \\
\hline Octopussy & 1983 & James Bond: Octopussy \\
\hline Amadeus & 1984 & Amadeus \\
\hline The Karate Kid & 1984 & Karate Kid \\
\hline Ran & 1985 & Ran \\
\hline & & \\
\hline & Sald & Sald \\
\hline
\end{tabular}




\begin{tabular}{|c|c|c|}
\hline Rocky IV & 1985 & Rocky 4 \\
\hline Rambo: First Blood Part II & 1985 & Rambo 2 \\
\hline The Goonies & 1985 & Goonies \\
\hline Top Gun & 1986 & Top Gun \\
\hline RoboCop & 1987 & Robocop \\
\hline Full Metal Jacket & 1987 & Full Metal Jacket \\
\hline Wall Street & 1987 & Wall Street \\
\hline Batman & 1989 & Batman \\
\hline JFK & 1991 & JFK \\
\hline Aladdin & 1992 & Aladdin \\
\hline Alien ${ }^{3}$ & 1992 & Alien 3 \\
\hline Philadelphia & 1993 & Philadelphia \\
\hline Forrest Gump & 1994 & Forrest Gump \\
\hline Apollo 13 & 1995 & Apollo 13 \\
\hline Jumanji & 1995 & Jumanji \\
\hline Trainspotting & 1996 & Trainspotting \\
\hline Fargo & 1996 & Fargo \\
\hline Jerry Maguire & 1996 & Jerry Maguire \\
\hline Titanic & 1997 & Titanic \\
\hline Armageddon & 1998 & Armageddon \\
\hline Blade & 1998 & Blade \\
\hline The Matrix & 1999 & Matrix \\
\hline Memento & 2000 & Memento \\
\hline X-Men & 2000 & X-Men \\
\hline Donnie Darko & 2001 & Donnie Darko \\
\hline Shrek & 2001 & Shrek \\
\hline Spider-Man & 2002 & Spider-Man \\
\hline X-Men 2 & 2003 & X-Men 2 \\
\hline Kill Bill: Vol. 1 & 2003 & Kill Bill \\
\hline The Matrix Reloaded & 2003 & Matrix Reloaded \\
\hline The Matrix Revolutions & 2003 & Matrix: Revolutions \\
\hline Spider-Man 2 & 2004 & Spider-Man 2 \\
\hline
\end{tabular}




\begin{tabular}{|l|l|l|}
\hline Kill Bill: Vol. 2 & 2004 & Kill Bill 2 \\
\hline Sin City & 2005 & Sin City \\
\hline King Kong & 2005 & King Kong \\
\hline 300 & 2006 & 300 \\
\hline Casino Royale & 2006 & Casino Royale \\
\hline Superbad & 2007 & Superbad \\
\hline Juno & 2007 & Juno \\
\hline Spider-Man 3 & 2007 & Spider-Man 3 \\
\hline WALL·E & 2008 & WALL·E \\
\hline Iron Man & 2008 & Iron Man \\
\hline Gran Torino & 2008 & Gran Torino \\
\hline Hancock & 2008 & Hancock \\
\hline Sherlock Holmes & 2009 & Sherlock Holmes \\
\hline Iron Man 2 & 2010 & Iron Man 2 \\
\hline Kick-Ass & 2010 & Kick Ass \\
\hline Thor & 2011 & Thor \\
\hline Skyfall & 2012 & Skyfall \\
\hline Ted & 2012 & Ted \\
\hline Argo & 2012 & Argo \\
\hline Iron Man Three & 2013 & Iron Man 3 \\
\hline Interstellar & 2014 & Interstellar \\
\hline Ant-Man & 2015 & Ant-Man \\
\hline Ex Machina & 2015 & Ex Machina \\
\hline Deadpool & 2016 & Deadpool \\
\hline X-Men: Apocalypse & 2016 & X-Men: Apocalypse \\
\hline La La Land & 2016 & La La Land \\
\hline Wonder Woman & 2017 & Wonder Woman \\
\hline Dunkirk & 2017 & Dunkirk \\
\hline Logan & 2017 & Logan: Wolverine \\
\hline John Wick: Chapter 2 & 2017 & John Wick 2 \\
\hline
\end{tabular}




\subsection{Combinations of translation and transcription (CTTs)}

\begin{tabular}{|l|l|l|}
\hline Steamboat Bill, Jr. & 1928 & Steamboat Bill ml. \\
\hline Dr. Jekyll and Mr. Hyde & 1931 & Dr. Jekyll i Mr. Hyde \\
\hline X-Men: The Last Stand & 2006 & X-Men: Posljednja fronta \\
\hline X-Men: Days of Future Past & 2014 & X-Men: Dani buduće prošlosti \\
\hline Batman v Superman: Dawn of Justice & 2016 & Batman v Superman: Zora pravednika \\
\hline Rogue One: A Star Wars Story & 2016 & Rogue One: Priča iz Ratova zvijezda \\
\hline Guardians of the Galaxy Vol. 2 & 2017 & Čuvari galaksije Vol. 2 \\
\hline
\end{tabular}

\section{German subcorpus}

\subsection{Direct translation}

\begin{tabular}{|l|l|l|}
\hline La souriante Madame Beudet & 1923 & Das Lächeln der Madame Beudet \\
\hline The Pilgrim & 1923 & Der Pilger \\
\hline Three Ages & 1923 & Drei Zeitalter \\
\hline The Love Nest & 1923 & Das Liebesnest \\
\hline The Ten Commandments & 1923 & Die zehn Gebote \\
\hline Greed & 1924 & Gier \\
\hline The Navigator & 1924 & Der Navigator \\
\hline The Thief of Bagdad & 1924 & Der Dieb von Bagdad \\
\hline Girl Shy & 1924 & Mädchenscheu \\
\hline The Gold Rush & 1925 & Der Goldrausch \\
\hline The Big Parade & 1925 & Die große Parade \\
\hline The Lost World & 1925 & Die verlorene Welt \\
\hline Bronenosets Potyomkin & 1925 & Panzerkreuzer Potemkin \\
\hline Stachka & 1925 & Streik \\
\hline The Phantom of the Opera & 1925 & Das Phantom der Oper \\
\hline
\end{tabular}




\begin{tabular}{|c|c|c|}
\hline Seven Chances & 1925 & Sieben Chancen \\
\hline The Lost World & 1925 & Die verlorene Welt \\
\hline The General & 1926 & Der General \\
\hline Mat & 1926 & Die Mutter \\
\hline Kurutta ippêji & 1926 & Eine Seite des Wahnsinns \\
\hline The Son of the Sheik & 1926 & Der Sohn des Scheichs \\
\hline Sunrise: A Song of Two Humans & 1927 & Sonnenaufgang - Lied von zwei Menschen \\
\hline The Kid Brother & 1927 & Der kleine Bruder \\
\hline The Jazz Singer & 1927 & Der Jazzsänger \\
\hline La passion de Jeanne d'Arc & 1928 & Die Passion der Jungfrau von Orléans \\
\hline The Circus & 1928 & Der Zirkus \\
\hline The Cameraman & 1928 & Der Kameramann \\
\hline Oktyabr & 1928 & Oktober \\
\hline The Wind & 1928 & Der Wind \\
\hline The Man Who Laughs & 1928 & Der Mann, der lacht \\
\hline Un chien andalou & 1929 & Ein andalusischer Hund \\
\hline Blackmail & 1929 & Erpressung \\
\hline The Skeleton Dance & 1929 & Tanz der Skelette \\
\hline Chelovek s kino-apparatom & 1929 & Der Mann mit der Kamera \\
\hline L'âge d'or & 1930 & Das goldene Zeitalter \\
\hline Zemlya & 1930 & Erde \\
\hline The Public Enemy & 1931 & Der öffentliche Feind \\
\hline City Lights & 1931 & Lichter der Großstadt \\
\hline Little Caesar & 1931 & Der kleine Cäsar \\
\hline The Mummy & 1932 & Die Mumie \\
\hline Scarface & 1932 & Narbengesicht \\
\hline Queen Christina & 1933 & Königin Christine \\
\hline Gold Diggers of 1933 & 1933 & Goldgräber von 1933 \\
\hline 42nd Street & 1933 & Die 42. Straße \\
\hline Dinner at Eight & 1933 & Dinner um acht \\
\hline It Happened One Night & 1934 & Es geschah in einer Nacht \\
\hline The Thin Man & 1934 & Der dünne Mann \\
\hline
\end{tabular}




\begin{tabular}{|c|c|c|}
\hline The Man Who Knew Too Much & 1934 & Der Mann, der zuviel wusste \\
\hline The Black Cat & 1934 & Die schwarze Katze \\
\hline The Scarlet Empress & 1934 & Die scharlachrote Kaiserin \\
\hline Bride of Frankenstein & 1935 & Frankensteins Braut \\
\hline The 39 Steps & 1935 & Die 39 Stufen \\
\hline Mutiny on the Bounty & 1935 & Meuterei auf der Bounty \\
\hline Modern Times & 1936 & Moderne Zeiten \\
\hline My Man Godfrey & 1936 & Mein Mann Godfrey \\
\hline Mr. Deeds Goes to Town & 1936 & Mr. Deeds geht in die Stadt \\
\hline Sabotage & 1936 & Sabotage \\
\hline The Petrified Forest & 1936 & Der versteinerte Wald \\
\hline Otto e mezzo & 1936 & Achteinhalb \\
\hline La grande illusion & 1937 & Die große Illusion \\
\hline The Awful Truth & 1937 & Die schreckliche Wahrheit \\
\hline Young and Innocent & 1937 & Jung und unschuldig \\
\hline Stage Door & 1937 & Bühneneingang \\
\hline Snow White and the Seven Dwarfs & 1937 & Schneewittchen und die sieben Zwerge \\
\hline Le quai des brumes & 1938 & Hafen im Nebel \\
\hline La règle du jeu & 1939 & Die Spielregel \\
\hline The Women & 1939 & Die Frauen \\
\hline The Roaring Twenties & 1939 & Die wilden Zwanziger \\
\hline The Wizard of $\mathrm{Oz}$ & 1939 & Der Zauberer von Oz \\
\hline Wuthering Heights & 1939 & Sturmhöhe \\
\hline The Great Dictator & 1940 & Der große Diktator \\
\hline Foreign Correspondent & 1940 & Der Auslandskorrespondent \\
\hline The Thief of Bagdad & 1940 & Der Dieb von Bagdad \\
\hline The Grapes of Wrath & 1940 & Früchte des Zorns \\
\hline Citizen Kane & 1941 & Bürger Kane \\
\hline Suspicion & 1941 & Verdacht \\
\hline Sullivan's Travels & 1941 & Sullivans Reisen \\
\hline The Wolf Man & 1941 & Der Wolfmensch \\
\hline To Be or Not to Be & 1942 & Sein oder Nichtsein \\
\hline
\end{tabular}




\begin{tabular}{|c|c|c|}
\hline Cat People & 1942 & Katzenmenschen \\
\hline Le corbeau & 1943 & Der Rabe \\
\hline For Whom the Bell Tolls & 1943 & Wem die Stunde schlägt \\
\hline Lifeboat & 1944 & Das Rettungsboot \\
\hline The Three Caballeros & 1944 & Drei Caballeros \\
\hline Murder, My Sweet & 1944 & Mord, meine Liebling \\
\hline Roma città aperta & 1945 & Rom, offene Stadt \\
\hline The Lost Weekend & 1945 & Das verlorene Wochenende \\
\hline Detour & 1945 & Umleitung \\
\hline The Picture of Dorian Gray & 1945 & Das Bildnis des Dorian Gray \\
\hline Notorious & 1946 & Berüchtigt \\
\hline The Best Years of Our Lives & 1946 & Die besten Jahre unseres Lebens \\
\hline The Lady from Shanghai & 1947 & Die Lady von Schanghai \\
\hline The Paradine Case & 1947 & Der Fall Paradin \\
\hline Black Narcissus & 1947 & Die schwarze Narzisse \\
\hline Ladri di biciclette & 1948 & Fahrraddiebe \\
\hline The Treasure of the Sierra Madre & 1948 & Der Schatz der Sierra Madre \\
\hline The Red Shoes & 1948 & Die roten Schuhe \\
\hline The Heiress & 1949 & Die Erbin \\
\hline The Third Man & 1949 & Der dritte Mann \\
\hline Nora inu & 1949 & Ein streunender Hund \\
\hline All About Eve & 1950 & Alles über Eva \\
\hline The Asphalt Jungle & 1950 & Asphalt-Dschungel \\
\hline Los ovidados & 1950 & Die Vergessenen \\
\hline The Day the Earth Stood Still & 1951 & Der Tag, an dem die Erde stillstand \\
\hline The Thing from Another World & 1951 & Das Ding aus einer anderen Welt \\
\hline A Place in the Sun & 1951 & Ein Platz an der Sonne \\
\hline Alice in Wonderland & 1951 & Alice im Wunderland \\
\hline High Noon & 1952 & Zwölf Uhr Mittags \\
\hline Limelight & 1952 & Rampenlicht \\
\hline The Greatest Show on Earth & 1952 & Die größte Schau der Welt \\
\hline Jeux interdits & 1952 & Verbotene Spiele \\
\hline
\end{tabular}




\begin{tabular}{|c|c|c|}
\hline Le salaire de la peur & 1953 & Lohn der Angst \\
\hline The War of the Worlds & 1953 & Kampf der Welten \\
\hline White Christmas & 1954 & Weiße Weihnachten \\
\hline Shichinin no samurai & 1954 & Die sieben Samurai \\
\hline 20,000 Leagues Under the Sea & 1954 & 20000 Meilen unter dem Meer \\
\hline Les diaboliques & 1955 & Die Teuflischen \\
\hline The Night of the Hunter & 1955 & Die Nacht des Jägers \\
\hline The Ten Commandments & 1956 & Die zehn Gebote \\
\hline The Man Who Knew Too Much & 1956 & Der Mann, der zuviel wusste \\
\hline The King and I & 1956 & Der König und ich \\
\hline The Wrong Man & 1956 & Der falsche Mann \\
\hline Around the World in Eighty Days & 1956 & In 80 Tagen um die Welt \\
\hline Le notti di Cabiria & 1957 & Die Nächte der Cabiria \\
\hline Witness for the Prosecution & 1957 & Zeugin der Klage \\
\hline Det sjunde inseglet & 1957 & Das siebente Siegel \\
\hline Mon oncle & 1958 & Mein Onkel \\
\hline Cat on a Hot Tin Roof & 1958 & Die Katze auf dem heißen Blechdach \\
\hline Ascenseur pour l'échafaud & 1958 & Fahrstuhl zum Schafott \\
\hline The Fly & 1958 & Die Fliege \\
\hline Some Like It Hot & 1959 & Manche mögen's heiß \\
\hline Plan 9 from Outer Space & 1959 & Plan 9 aus dem Weltall \\
\hline House on Haunted Hill & 1959 & Das Haus auf dem Geisterhügel \\
\hline Sleeping Beauty & 1959 & Dornröschen \\
\hline Anatomy of a Murder & 1959 & Anatomie eines Mordes \\
\hline The Apartment & 1960 & Das Appartement \\
\hline The Magnificent Seven & 1960 & Die glorreichen Sieben \\
\hline À bout de souffle & 1960 & Außer Atem \\
\hline La dolce vita & 1960 & Das süße Leben \\
\hline The Time Machine & 1960 & Die Zeitmaschine \\
\hline Jungfrukällan & 1960 & Die Jungfrauenquelle \\
\hline Breakfast at Tiffany's & 1961 & Frühstück bei Tiffany \\
\hline One Hundred and One Dalmatians & 1961 & 101 Dalmatiner \\
\hline
\end{tabular}




\begin{tabular}{|c|c|c|}
\hline The Guns of Navarone & 1961 & Die Kanonen von Navarone \\
\hline Såsom i en spegel & 1961 & Wie in einem Spiegel \\
\hline Lawrence of Arabia & 1962 & Lawrence von Arabien \\
\hline The Man Who Shot Liberty Valance & 1962 & Der Mann, der Liberty Valance erschoß \\
\hline The Longest Day & 1962 & Der längste Tag \\
\hline What Ever Happened to Baby Jane? & 1962 & Was geschah wirklich mit Baby Jane? \\
\hline Jules et Jim & 1962 & Jules und Jim \\
\hline The Pink Panther & 1963 & Der rosarote Panther \\
\hline The Birds & 1963 & Die Vögel \\
\hline A Shot in the Dark & 1964 & Ein Schuß im Dunkeln \\
\hline Per un pugno di dollari & 1964 & Für eine Handvoll Dollar \\
\hline Repulsion & 1965 & Ekel \\
\hline The Flight of the Phoenix & 1965 & Der Flug des Phönix \\
\hline Per qualche dollaro in più & 1965 & Für ein paar Dollar mehr \\
\hline Doctor Zhivago & 1965 & Doktor Schiwago \\
\hline A Man for All Seasons & 1966 & Ein Mann zu jeder Jahreszeit \\
\hline La battaglia di Algeri & 1966 & Schlacht um Algier \\
\hline Who's Afraid of Virginia Woolf? & 1966 & Wer hat Angst vor Virginia Woolf? \\
\hline The Dirty Dozen & 1967 & Das dreckige Dutzend \\
\hline In the Heat of the Night & 1967 & In der Hitze der Nacht \\
\hline Bonnie and Clyde & 1967 & Bonnie und Clyde \\
\hline The Jungle Book & 1967 & Das Dschungelbuch \\
\hline 2001: A Space Odyssey & 1968 & 2001: Odyssee im Weltraum \\
\hline Rosemary's Baby & 1968 & Rosemaries Baby \\
\hline Night of the Living Dead & 1968 & Die Nacht der lebenden Toten \\
\hline Planet of the Apes & 1968 & Planet der Affen \\
\hline L'armée des ombres & 1969 & Armee im Schatten \\
\hline A Clockwork Orange & 1971 & Uhrwerk Orange \\
\hline Duel & 1971 & Duell \\
\hline The Godfather & 1972 & Der Pate \\
\hline Ultimo tango a Parigi & 1972 & Der letzte Tango in Paris \\
\hline The Exorcist & 1973 & Der Exorzist \\
\hline
\end{tabular}




\begin{tabular}{|c|c|c|}
\hline Young Frankenstein & 1974 & Frankenstein Junior \\
\hline Murder on the Orient Express & 1974 & Mord im Orient Express \\
\hline One Flew Over the Cuckoo's Nest & 1975 & Einer flog über das Kuckucksnest \\
\hline Three Days of the Condor & 1975 & Die drei Tage des Condor \\
\hline The Omen & 1976 & Das Omen \\
\hline Marathon Man & 1976 & Der Marathon-Mann \\
\hline Life of Brian & 1979 & Das Leben des Brian \\
\hline Kramer vs. Kramer & 1979 & Kramer gegen Kramer \\
\hline Escape from Alcatraz & 1979 & Flucht von Alcatraz \\
\hline The Elephant Man & 1980 & Der Elefantenmensch \\
\hline Friday the 13th & 1980 & Freitag der 13. \\
\hline The Blue Lagoon & 1980 & Die blaue Lagune \\
\hline E.T. the Extra-Terrestrial & 1982 & E.T. - Der Außerirdische \\
\hline Conan the Barbarian & 1982 & Conan der Barbar \\
\hline The Meaning of Life & 1983 & Der Sinn des Lebens \\
\hline Back to the Future & 1985 & Zurück in die Zukunft \\
\hline The Goonies & 1985 & Die Goonies \\
\hline Tenkû no shiro Rapyuta & 1986 & Das Schloss im Himmel \\
\hline The Princess Bride & 1987 & Die Braut des Prinzen \\
\hline Tonari no Totoro & 1988 & Mein Nachbar Totoro \\
\hline Indiana Jones and the Last Crusade & 1989 & Indiana Jones und der letzte Kreuzzug \\
\hline Dead Poets Society & 1989 & Der Club der toten Dichter \\
\hline Honey, I Shrunk the Kids & 1989 & Liebling, ich habe die Kinder geschrumpft \\
\hline Back to the Future Part II & 1989 & Zurück in die Zukunft II \\
\hline Back to the Future Part III & 1990 & Zurück in die Zukunft III \\
\hline The Silence of the Lambs & 1991 & Das Schweigen der Lämmer \\
\hline Beauty and the Beast & 1991 & Die Schöne und das Biest \\
\hline Cape Fear & 1991 & Kap der Angst \\
\hline Terminator 2: Judgment Day & 1991 & Terminator 2 - Tag der Abrechnung \\
\hline Terminator 2: Judgment Day & 1991 & Terminator 2 - Tag der Abrechnung \\
\hline Schindler's List & 1993 & Schindlers Liste \\
\hline Dumb \& Dumber & 1994 & Dumm und Dümmer \\
\hline
\end{tabular}




\begin{tabular}{|l|l|l|}
\hline The Mask & 1994 & Die Maske \\
\hline The Usual Suspects & 1995 & Die üblichen Verdächtigen \\
\hline Se7en & 1995 & Sieben \\
\hline Le cinquième élément & 1997 & Das fünfte Element \\
\hline La vita è bella & 1997 & Das Leben ist schön \\
\hline The Truman Show & 1998 & Die Truman Show \\
\hline The Mummy & 1999 & Die Mumie \\
\hline The Pianist & 2002 & Der Pianist \\
\hline The Bourne Identity & 2002 & Die Bourne Identität \\
\hline The Lord of the Rings: The Two Towers & 2002 & Der Herr der Ringe: Die zwei Türme \\
\hline The Lord of the Rings: The Return of the King & 2003 & Der Herr der Ringe: Die Rückkehr des Königs \\
\hline Troy & 2004 & Troja \\
\hline Harry Potter and the Prisoner of Azkaban & 2004 & Harry Potter und der Gefangene von Askaban \\
\hline V for Vendetta & 2005 & V wie Vendetta \\
\hline Harry Potter and the Goblet of Fire & 2005 & Harry Potter und der Feuerkelch \\
\hline War of the Worlds & 2005 & Krieg der Welten \\
\hline Charlie and the Chocolate Factory & 2005 & Charlie und die Schokoladenfabrik \\
\hline The Bourne Ultimatum & 2007 & Das Bourne Ultimatum \\
\hline Indiana Jones and the Kingdom of the Crystall Skull & 2008 & Indiana Jones und das Königreich des Kristallschädels \\
\hline The Curious Case of Benjamin Button & 2008 & Der seltsame Fall des Benjamin Button \\
\hline Up & 2009 & Oben \\
\hline Harry Potter and the Deathly Hollows: Part 2 & 2011 & Harry Potter und die Heiligtümer des Todes - Teil 2 \\
\hline The Hobbit: An Unexpected Journey & 2012 & Der Hobbit: Eine unerwartete Reise \\
\hline The Hobbit: The Desolation of Smaug & 2013 & Der Hobbit: Smaugs Einöde \\
\hline John Wick: Chapter 2 & 2017 & John Wick: Kapitel 2 \\
\hline The Beauty and the Beast & 2017 & Die Schöne und das Biest \\
\hline It & 2017 & Es \\
\hline & & \\
\hline
\end{tabular}




\subsection{Free translation}

\begin{tabular}{|c|c|c|}
\hline Our Hospitality & 1923 & Verflixte Gastfreundschaft \\
\hline The Hunchback of Notre Dame & 1923 & Der Glöckner von Notre Dame \\
\hline He Who Gets Slapped & 1924 & Der Mann, der die Ohrfeigen bekam \\
\hline Ben-Hur: A Tale of the Christ & 1925 & Ben Hur \\
\hline The Black Pirate & 1926 & Der Seeräuber \\
\hline Napoléon vu par Abel Gance & 1927 & Napoleon \\
\hline The Lodger: A Story of the London Fog & 1927 & Der Mieter \\
\hline Big Business & 1929 & Laurel und Hardy: Das große Geschäft \\
\hline Murder! & 1930 & Mord - Sir John greift ein! \\
\hline Morocco & 1930 & Marokko - Herzen in Flammen \\
\hline Hell's Angels & 1930 & Höllenflieger \\
\hline The Big Trail & 1930 & Der große Treck \\
\hline All Quiet on the Western Front & 1930 & Im Westen nichts Neues \\
\hline Trouble in Paradise & 1932 & Ärger im Paradies \\
\hline Grand Hotel & 1932 & Menschen im Hotel \\
\hline The Invisible Man & 1933 & Der Unsichtbare \\
\hline Sons of the Desert & 1933 & Laurel und Hardy: Die Wüstensöhne \\
\hline A Night at the Opera & 1935 & Skandal in der Oper \\
\hline Fury & 1936 & Blinde Wut \\
\hline After the Thin Man & 1936 & Dünner Mann, 2. Fall \\
\hline A Day at the Races & 1937 & Die Marx Brothers: Ein Tag beim Rennen \\
\hline A Star Is Born & 1937 & Ein Stern geht auf \\
\hline The Lady Vanishes & 1938 & Eine Dame verschwindet \\
\hline The Lady Vanishes & 1938 & Eine Dame verschwindet \\
\hline Angels with Dirty Faces & 1938 & Chicago - Engel mit schmutzigen Gesichtern \\
\hline The Adventures of Robin Hood & 1938 & Robin Hood, König der Vagabunden \\
\hline Gone with the Wind & 1939 & Vom Winde verweht \\
\hline The Maltese Falcon & 1941 & Die Spur des Falken \\
\hline High Sierra & 1941 & Entscheidung in der Sierra \\
\hline
\end{tabular}




\begin{tabular}{|c|c|c|}
\hline Saboteur & 1942 & Saboteure \\
\hline The Magnificent Ambersons & 1942 & Der Glanz des Hauses Amberson \\
\hline Shadow of a Doubt & 1943 & Im Schatten des Zweifels \\
\hline Vredens dag & 1943 & Tag der Rache \\
\hline The Ox-Bow Incident & 1943 & Ritt zum Ox-Bow \\
\hline The Life and Death of Colonel Blimp & 1943 & Leben und Sterben des Colonel Blimp \\
\hline To Have and Have Not & 1944 & Haben und Nichthaben \\
\hline Arsenic and Old Lace & 1944 & Arsen und Spitzenhäubchen \\
\hline Brief Encounter & 1945 & Begegnung \\
\hline Scarlet Street & 1945 & Straße der Versuchung \\
\hline Les enfants du paradis & 1945 & Kinder des Olymp \\
\hline Miracle on 34th Street & 1947 & Das Wunder von Manhattan \\
\hline Dark Passage & 1947 & Die schwarze Natter \\
\hline The Ghost and Mrs. Muir & 1947 & Ein Gespenst auf Freiersfüßen \\
\hline Bud Abbott and Lou Costello Meet Frankenstein & 1948 & Abbott und Costello treffen Frankenstein \\
\hline The Naked City & 1948 & Stadt ohne Maske \\
\hline In a Lonely Place & 1950 & Ein einsamer Ort \\
\hline Strangers on a Train & 1951 & Der Fremde im Zug \\
\hline A Streetcar Named Desire & 1951 & Endstation Sehnsucht \\
\hline Gentlemen Prefer Blondes & 1953 & Blondinen bevorzugt \\
\hline Tôkyô monogatari & 1953 & Die Reise nach Tokio \\
\hline From Here to Eternity & 1953 & Verdammt in alle Ewigkeit \\
\hline Dial M for Murder & 1954 & Bei Anruf Mord \\
\hline Rear Window & 1954 & Das Fenster zum Hof \\
\hline The Caine Mutiny & 1954 & Die Caine war ihr Schicksal \\
\hline Du rififi chez les hommes & 1955 & Rififi \\
\hline East of Eden & 1955 & Jenseits von Eden \\
\hline The Trouble with Harry & 1955 & Immer Ärger mit Harry \\
\hline The Seven Year Itch & 1955 & Das verflixte 7. Jahr \\
\hline Giant & 1956 & Giganten \\
\hline The Bridge on the River Kwai & 1957 & Die Brücke am Kwei \\
\hline Smultronstället & 1957 & Wilde Erdbeeren \\
\hline
\end{tabular}




\begin{tabular}{|c|c|c|}
\hline Paths of Glory & 1957 & Wege zum Ruhm \\
\hline 12 Angry Men & 1957 & Die zwölf Geschworenen \\
\hline Kakushi-toride no san-akunin & 1958 & Die verborgene Festung \\
\hline Touch of Evil & 1958 & Im Zeichen des Bösen \\
\hline Judgment at Nuremberg & 1961 & Das Urteil von Nürnberg \\
\hline It's a Mad Mad Mad Mad World & 1963 & Eine total, total verrückte Welt \\
\hline From Russia with Love & 1963 & James Bond 007 - Liebesgrüße aus Moskau \\
\hline Rudolph, the Red-Nosed Reindeer & 1964 & Rudolph mit der roten Nase \\
\hline $\begin{array}{l}\text { Dr. Strangelove or: How I Learned to Stop Worrying and Love } \\
\text { the Bomb }\end{array}$ & 1964 & Dr. Seltsam, oder wie ich lernte, die Bombe zu lieben \\
\hline Help! & 1965 & $\mathrm{Hi}-\mathrm{Hi}-\mathrm{Hilfe}$ \\
\hline Thunderball & 1965 & James Bond 007 - Feuerball \\
\hline You Only Live Twice & 1967 & James Bond 007 - Man lebt nur zweimal \\
\hline Hang 'Em High & 1968 & Hängt ihn höher \\
\hline The Party & 1968 & Der Partyschreck \\
\hline On Her Majesty's Secret Service & 1969 & James Bond 007 - Im Geheimdienst Ihrer Majestät \\
\hline Midnight Cowboy & 1969 & Asphalt-Cowboy \\
\hline Battle of Britain & 1969 & Luftschlacht um England \\
\hline Beneath the Planet of the Apes & 1970 & Rückkehr zum Planet der Affen \\
\hline Willy Wonka \& the Chocolate Factory & 1971 & Charlie und die Schokoladenfabrik \\
\hline The Last Picture Show & 1971 & Die letzte Vorstellung \\
\hline Diamonds are Forever & 1971 & James Bond 007 - Diamantenfieber \\
\hline $\begin{array}{l}\text { Everything You Always Wanted to Know About Sex * But Were } \\
\text { Afraid to Ask }\end{array}$ & 1972 & Was Sie schon immer über Sex wissen wollten \\
\hline The Poseidon Adventure & 1972 & Die Höllenfahrt der Poseidon \\
\hline Live and Let Die & 1973 & James Bond 007 - Leben und sterben lassen \\
\hline The Godfather: Part II & 1974 & Der Pate 2 \\
\hline The Conversation & 1974 & Der Dialog \\
\hline The Towering Inferno & 1974 & Flammendes Inferno \\
\hline The Man with the Golden Gun & 1974 & James Bond 007 - Der Mann mit dem goldenen Colt \\
\hline Dog Day Afternoon & 1975 & Hundstage \\
\hline Salò o le 120 giornate di Sodoma & 1975 & Die 120 Tage von Sodom \\
\hline
\end{tabular}




\begin{tabular}{|c|c|c|}
\hline The Man Who Would Be King & 1975 & Der Mann, der König sein wollte \\
\hline The Enforcer & 1976 & Dirty Harry III - Der Unerbittliche \\
\hline Logan's Run & 1976 & Flucht ins 23. Jahrhundert \\
\hline Star Wars & 1977 & Krieg der Sterne \\
\hline The Spy Who Loved Me & 1977 & James Bond 007 - Der Spion, der mich liebte \\
\hline A Bridge Too Far & 1977 & Die Brücke von Arnheim \\
\hline Close Encounters of the Third Kind & 1977 & Unheimliche Begegnung der dritten Art \\
\hline Invasion of the Body Snatchers & 1978 & Die Körperfresser kommen \\
\hline Star Wars: Episode V - The Empire Strikes Back & 1980 & Das Imperium schlägt zurück \\
\hline Airplane! & 1980 & Die unglaubliche Reise in einem verrückten Flugzeug \\
\hline Raging Bull & 1980 & Wie ein wilder Stier \\
\hline Raiders of the Lost Ark & 1981 & Jäger des verlorenen Schatzes \\
\hline The Thing & 1982 & Das Ding aus einer anderen Welt \\
\hline Star Trek: The Wrath of Khan & 1982 & Star Trek II: Der Zorn des Khan \\
\hline Star Wars: Episode VI - Return of the Jedi & 1983 & Die Rückkehr der Jedi-Ritter \\
\hline A Christmas Story & 1983 & Fröhliche Weihnachten \\
\hline Risky Business & 1983 & Lockere Geschäfte \\
\hline Star Wars: Episode VI - Return of the Jedi & 1983 & Die Rückkehr der Jedi-Ritter \\
\hline Indiana Jones and the Temple of Doom & 1984 & Indiana Jones und der Tempel des Todes \\
\hline Commando & 1985 & Das Phantom Kommando \\
\hline Mad Max Beyond Thunderdome & 1985 & Mad Max III - Jenseits der Donnerkuppel \\
\hline Labyrinth & 1986 & Die Reise ins Labyrinth \\
\hline Ferris Bueller's Day Off & 1986 & Ferris macht blau \\
\hline The Naked Gun: From the Files of Police Squad! & 1988 & Die nackte Kanone \\
\hline Die Hard & 1988 & Stirb langsam \\
\hline Who Framed Roger Rabbit & 1988 & Falsches Spiel mit Roger Rabbit \\
\hline Hotaru no haka & 1988 & Die letzten Glühwürmchen \\
\hline Back to the Future Part II & 1989 & Zurück in die Zukunft II \\
\hline When Harry Met Sally... & 1989 & Harry und Sally \\
\hline The Little Mermaid & 1989 & Arielle, die Meerjungfrau \\
\hline The Godfather: Part III & 1990 & Der Pate 3 \\
\hline Back to the Future Part III & 1990 & Zurück in die Zukunft III \\
\hline
\end{tabular}




\begin{tabular}{|c|c|c|}
\hline Edward Scissorhands & 1990 & Edward mit den Scherenhänden \\
\hline Dances with Wolves & 1990 & Der mit dem Wolf tanzt \\
\hline Home Alone & 1990 & Kevin - Allein zu Haus \\
\hline Die Hard 2 & 1990 & Stirb langsam 2 \\
\hline Robin Hood: Prince of Thieves & 1991 & Robin Hood - König der Diebe \\
\hline Batman Returns & 1992 & Batmans Rückkehr \\
\hline Scent of a Woman & 1992 & Der Duft der Frauen \\
\hline Groundhog Day & 1993 & Und täglich grüßt das Murmeltier \\
\hline What's Eating Gilbert Grape & 1993 & Gilbert Grape - Irgendwo in Iowa \\
\hline The Lion King & 1994 & Der König der Löwen \\
\hline Ace Ventura: Pet Detective & 1994 & Ace Ventura - Ein tierischer Detektiv \\
\hline Interview with the Vampire: The Vampire Chronicles & 1994 & Interview mit einem Vampir \\
\hline The Devil's Advocate & 1997 & Im Auftrag des Teufels \\
\hline There's Something About Mary & 1998 & Verrückt nach Mary \\
\hline Saving Private Ryan & 1998 & Der Soldat James Ryan \\
\hline Monsters, Inc. & 2001 & Die Monster AG \\
\hline The Lord of the Rings: The Fellowship of the Ring & 2001 & Der Herr der Ringe: Die Gefährten \\
\hline Harry Potter and the Sorcerer's Stone & 2001 & Harry Potter und der Stein der Weisen \\
\hline Le fabuleux destin d'Amélie Poulain & 2001 & Die fabelhafte Welt der Amélie \\
\hline Harry Potter and the Chamber of Secrets & 2002 & Harry Potter und die Kammer des Schreckens \\
\hline Finding Nemo & 2003 & Findet Nemo \\
\hline The 40 Year Old Virgin & 2005 & Jungfrau (40), männlich, sucht ... \\
\hline El laberinto del fauno & 2006 & Pans Labyrinth \\
\hline How to Train Your Dragon & 2010 & Drachenzähmen leicht gemacht \\
\hline Limitless & 2011 & Ohne Limit \\
\hline Rise of the Planet of the Apes & 2011 & Planet der Affen: Prevolution \\
\hline Frozen & 2013 & Die Eiskönigin - Völlig unverfroren \\
\hline Star Wars: Episode VII - The Force Awakens & 2015 & Star Wars: Episode VII - Das Erwachen der Macht \\
\hline Inside Out & 2015 & Alles steht Kopf \\
\hline The Martian & 2015 & Der Marsianer - Rettet Mark Watney \\
\hline Zootopia & 2016 & Zoomania \\
\hline
\end{tabular}




\begin{tabular}{|c|c|c|}
\hline Safety Last! & 1923 & Ausgerechnet Wolkenkratzer! \\
\hline A Woman of Paris: A Drama of Fate & 1923 & Die Nächte einer schönen Frau \\
\hline The Freshman & 1925 & Der Sportstudent \\
\hline Go West & 1925 & Der Cowboy \\
\hline Flesh and the Devil & 1926 & Es war \\
\hline Battling Butler & 1926 & Der Killer von Alabama \\
\hline College & 1927 & Der Musterschüler \\
\hline The Crowd & 1928 & Ein Mensch der Masse \\
\hline Show People & 1928 & Es tut sich was in Hollywood \\
\hline Monkey Business & 1931 & Die Marx Brothers auf See \\
\hline Cimarron & 1931 & Pioniere des Wilden Westens \\
\hline Horse Feathers & 1932 & Blühender Blödsinn \\
\hline I Am a Fugitive from a Chain Gang & 1932 & Jagd auf James A. \\
\hline The Most Dangerous Game & 1932 & Graf Zaroff - Genie des Bösen \\
\hline Duck Soup & 1933 & Die Marx Brothers im Krieg \\
\hline The Gay Divorcee & 1934 & Tanz mit mir! \\
\hline Twentieth Century & 1934 & Napoleon vom Broadway \\
\hline Babes in Toyland & 1934 & Laurel und Hardy: Rache ist süß \\
\hline Top Hat & 1935 & Ich tanz' mich in dein Herz hinein \\
\hline Captain Blood & 1935 & Unter Piratenflagge \\
\hline The Informer & 1935 & Der Verräter \\
\hline A Tale of Two Cities & 1935 & Flucht aus Paris \\
\hline Dodsworth & 1936 & Zeit der Liebe, Zeit des Abschieds \\
\hline Way Out West & 1937 & Laurel und Hardy: Zwei ritten nach Texas \\
\hline Lost Horizon & 1937 & In den Fesseln von Shangri-La \\
\hline Captains Courageous & 1937 & Manuel \\
\hline Holiday & 1938 & Die Schwester der Braut \\
\hline Pygmalion & 1938 & Der Roman eines Blumenmädchens \\
\hline Bringing Up Baby & 1938 & Leoparden küsst man nicht \\
\hline
\end{tabular}




\begin{tabular}{|c|c|c|}
\hline You Can't Take It with You & 1938 & Lebenskünstler \\
\hline Stagecoach & 1939 & Ringo \\
\hline Only Angles Have Wings & 1939 & S.O.S. Feuer an Bord \\
\hline The Philadelphia Story & 1940 & Die Nacht vor der Hochzeit \\
\hline His Girl Friday & 1940 & Sein Mädchen für besondere Fälle \\
\hline The Shop Around the Corner & 1940 & Rendezvous nach Ladenschluss \\
\hline The Lady Eve & 1941 & Die Falschspielerin \\
\hline How Green Was My Valley & 1941 & Schlagende Wetter \\
\hline Holiday Inn & 1942 & Musik, Musik \\
\hline Now, Voyager & 1942 & Reise aus der Vergangenheit \\
\hline Heaven Can Wait & 1943 & Ein himmlischer Sünder \\
\hline Gaslight & 1944 & Das Haus der Lady Alquist \\
\hline The Woman in the Window & 1944 & Gefährliche Begegnungen \\
\hline Double Indemnity & 1944 & Frau ohne Gewissen \\
\hline Spellbound & 1945 & Ich kämpfe um dich \\
\hline Mildred Pierce & 1945 & Solange ein Herz schlägt \\
\hline And Then There Were None & 1945 & Das letzte Wochenende \\
\hline La belle et la bête & 1946 & Es war einmal \\
\hline My Darling Clementine & 1946 & Faustrecht der Prärie \\
\hline It's a Wonderful Life & 1946 & Ist das Leben nicht schön \\
\hline The Big Sleep & 1946 & Tote schlafen fest \\
\hline Great Expectations & 1946 & Geheimnisvolle Erbschaft \\
\hline The Postman Always Rings Twice & 1946 & Im Netz der Leidenschaft \\
\hline The Killers & 1946 & Rache der Unterwelt \\
\hline Out of the Past & 1947 & Goldenes Gift \\
\hline Gentlemen's Agreement & 1947 & Tabu der Gerechten \\
\hline The Bishop's Wife & 1947 & Jede Frau braucht einen Engel \\
\hline Rope & 1948 & Cocktail für eine Leiche \\
\hline Key Largo & 1948 & Hafen des Lasters \\
\hline Fort Apache & 1948 & Bis zum letzten Mann \\
\hline Kind Hearts and Coronets & 1949 & Adel verpflichtet \\
\hline White Heat & 1949 & Sprung in den Tod \\
\hline
\end{tabular}




\begin{tabular}{|c|c|c|}
\hline Adam's Rib & 1949 & Ehekrieg \\
\hline She Wore a Yellow Ribbon & 1949 & Der Teufelshauptmann \\
\hline Twelve O'Clock High & 1949 & Der Kommandeur \\
\hline All the King's Men & 1949 & Der Mann, der herrschen wollte \\
\hline Ace in the Hole & 1951 & Reporter des Satans \\
\hline Scrooge & 1951 & Charles Dickens - Eine Weihnachtsgeschichte \\
\hline Singin' in the Rain & 1952 & Du sollst mein Glücksstern sein \\
\hline Monkey Business & 1952 & Liebling, ich werde jünger \\
\hline The Bad and the Beautiful & 1952 & Stadt der Illusionen \\
\hline The Quiet Man & 1952 & Der Sieger \\
\hline Roman Holiday & 1953 & Ein Herz und eine Krone \\
\hline The Big Heat & 1953 & Heiße eisen \\
\hline On the Waterfront & 1954 & Die Faust im Nacken \\
\hline Lady and the Tramp & 1955 & Susi und Strolch \\
\hline Rebel Without a Cause & 1955 & ...denn sie wissen nicht, was sie tun \\
\hline To Catch a Thief & 1955 & Über den Dächern von Nizza \\
\hline The Killing & 1956 & Die Rechnung ging nicht auf \\
\hline Forbidden Planet & 1956 & Alarm im Weltall \\
\hline The Searchers & 1956 & Der schwarze Falke \\
\hline An Affair to Remember & 1957 & Die große Liebe meines Lebens \\
\hline Sweet Smell of Success & 1957 & Dein Schicksal in meiner Hand \\
\hline Nort by Northwest & 1959 & Der unsichtbare Dritte \\
\hline Les quatre cents coups & 1959 & Sie küssten und sie schlugen ihn \\
\hline Peeping Tom & 1960 & Augen der Angst \\
\hline The Hustler & 1961 & Haie der Großstadt \\
\hline The Innocents & 1961 & Schloß des Schreckens \\
\hline The Manchurian Candidate & 1962 & Botschafter der Angst \\
\hline To Kill a Mockingbird & 1962 & Wer die Nachtigall stört \\
\hline The Great Escape & 1963 & Gesprengte Ketten \\
\hline The Sword in the Stone & 1963 & Die Hexe und der Zauberer \\
\hline The Haunting & 1963 & Bis das Blut gefriert \\
\hline A Hard Day's Night & 1964 & Yeah, Yeah, Yeah \\
\hline
\end{tabular}




\begin{tabular}{|c|c|}
\hline The Sound of Music & 1965 \\
\hline A Charlie Brown Christmas & 1965 \\
\hline Pierrot le fou & 1965 \\
\hline Alphaville, une étrange aventure de Lemmy Caution & 1965 \\
\hline How the Grinch Stole Christmas! & 1966 \\
\hline Il buono, il brutto, il cattivo & 1966 \\
\hline The Graduate & 1967 \\
\hline Cool Hand Luke & 1967 \\
\hline The Producers & 1967 \\
\hline Where Eagle Dares & 1968 \\
\hline C'era una volta il West & 1968 \\
\hline True Gift & 1969 \\
\hline Take the Money and Run & 1969 \\
\hline Kelly's Heroes & 1970 \\
\hline Five Easy Pieces & 1970 \\
\hline Straw Dogs & 1971 \\
\hline Deliverance & 1972 \\
\hline Sleuth & 1972 \\
\hline The Sting & 1973 \\
\hline Enter the Dragon & 1973 \\
\hline Mean Streets & 1973 \\
\hline The Texas Chain Saw Massacre & 1974 \\
\hline Blazing Saddles & 1974 \\
\hline Death Wish & 1974 \\
\hline Jaws & 1975 \\
\hline Monty Python and the Holy Grail & 1975 \\
\hline All the President's Men & 1976 \\
\hline The Outlaw Josey Wales & 1976 \\
\hline The Enforcer & 1976 \\
\hline Annie Hall & 1977 \\
\hline The Rescuers & 1977 \\
\hline Smokey and the Bandit & 1977 \\
\hline
\end{tabular}

Meine Lieder, meine Träume

Die Peanuts - Fröhliche Weihnachten

Elf Uhr nachts

Lemmy Caution gegen Alpha 60

Die gestohlenen Weihnachtsgeschenke

Zwei glorreiche Halunken

Die Reifeprüfung

Der Unbeugsame

Frühling für Hitler

Agenten sterben einsam

Spiel mir das Lied vom Tod

Der Marshal

Woody, der Unglücksrabe

Stoßtrupp Gold

Ein Mann sucht sich selbst

Wer Gewalt sät

Beim Sterben ist jeder der Erste

Mord mit kleinen Fehlern

Der Clou

Der Mann mit der Todeskralle

Hexenkessel

Blutgericht in Texas

Der Wilde Wilde Westen

Ein Mann sieht rot

Der weiße Hai

Die Ritter der Kokosnuß

Die Unbestechlichen

Der Texaner

Dirty Harry III - Der Unerbittliche

Der Stadtneurotiker

Bernard und Bianca - Die Mäusepolizei

1977 Ein ausgekochtes Schlitzohr 


\begin{tabular}{|c|c|c|}
\hline The Deer Hunter & 1978 & Die durch die Hölle gehen \\
\hline Animal House & 1978 & Ich glaub, mich tritt ein Pferd \\
\hline Jaws 2 & 1978 & Der weiße Hai 2 \\
\hline Days of Heaven & 1978 & In der Glut des Südens \\
\hline The Evil Dead & 1981 & Tanz der Teufel \\
\hline Escape from New York & 1981 & Die Klapperschlange \\
\hline The Fox and the Hound & 1981 & Cap und Capper \\
\hline Stripes & 1981 & Ich glaub' mich knutscht ein Elch! \\
\hline First Blood & 1982 & Rambo \\
\hline Trading Places & 1983 & Die Glücksritter \\
\hline National Lampoon's Vacation & 1983 & Die schrillen Vier auf Achse \\
\hline A Nightmare on Elm Street & 1984 & Nightmare - Mörderische Träume \\
\hline A View to Kill & 1985 & James Bond 007 - Im Angesicht des Todes \\
\hline Evil Dead II & 1987 & Tanz der Teufel 2 - Jetzt wird noch mehr getanzt \\
\hline Coming to America & 1988 & Der Prinz aus Zamunda \\
\hline Point Break & 1991 & Gefährliche Brandung \\
\hline Unforgiven & 1992 & Erbarmungslos \\
\hline Home Alone 2: Lost in New York & 1992 & Kevin - Allein in New York \\
\hline A Few Good Men & 1992 & Eine Frage der Ehre \\
\hline The Fugitive & 1993 & Auf der Flucht \\
\hline The Shawshank Redemption & 1994 & Die Verurteilten \\
\hline Die Hard with a Vengeance & 1995 & Stirb langsam - Jetzt erst recht \\
\hline Face/Off & 1997 & Im Körper des Feindes \\
\hline Lock, Stock and the Two Smoking Barrels & 1998 & Bube Dame König GrAs \\
\hline A Bug's Life & 1998 & Das große Krabbeln \\
\hline Meet the Parents & 2000 & Meine Braut, ihr Vater und ich \\
\hline Sen to Chihiro no kamikakushi & 2001 & Chihiros Reise ins Zauberland \\
\hline Cidade de Deus & 2002 & City of God \\
\hline Pirates of the Caribbean: The Curse of the Black Pearl & 2003 & Fluch der Karibik \\
\hline Oldeuboi & 2003 & Oldboy \\
\hline Eternal Sunshine of the Spotless Mind & 2004 & Vergiss mein nicht! \\
\hline The Notebook & 2004 & Wie ein einziger Tag \\
\hline
\end{tabular}




\begin{tabular}{|l|l|l|}
\hline Taken & 2008 & 96 Hours \\
\hline Despicable Me & 2010 & Ich - Einfach unverbesserlich \\
\hline X: First Class & 2011 & X-Men: Erste Entscheidung \\
\hline Intouchables & 2011 & Ziemlich beste Freunde \\
\hline Frozen & 2013 & Die Eiskönigin - Völlig unverfroren \\
\hline Captain America: The Winter Soldier & 2014 & The Return of the First Avenger \\
\hline
\end{tabular}

\subsection{Transcription}

\begin{tabular}{|l|l|l|}
\hline Entr'acte & 1924 & Entr'acte \\
\hline Sherlock Jr. & 1924 & Sherlock jr. \\
\hline Wings & 1927 & Wings \\
\hline The Unknown & 1927 & The Unknown - Der Unbekannte \\
\hline Steamboat Bill, Jr. & 1928 & Steamboat Bill, jr. \\
\hline Steamboat Willie & 1928 & Steamboat Willie \\
\hline The Broadway Melody & 1929 & The Broadway Melody \\
\hline Queen Kelly & 1929 & Queen Kelly \\
\hline The Cocoanuts & 1929 & The Cocoanuts \\
\hline Animal Crackers & 1930 & Animal Crackers \\
\hline Frankenstein & 1931 & Frankenstein \\
\hline Dracula & 1931 & Dracula \\
\hline Tabu: A Story of the South Seas & 1931 & Tabu \\
\hline Freaks & 1932 & Freaks \\
\hline White Zombie & 1932 & The White Zombie \\
\hline King Kong & 1933 & King Kong und die weiße Frau \\
\hline L'Atalante & 1934 & Atalante \\
\hline Anna Karenina & 1935 & Anna Karenina \\
\hline Swing Time & 1936 & Swing Time \\
\hline Reefer Madness & 1936 & Reefer Madness \\
\hline Aleksandr Nevskiy & 1938 & Alexander Newski \\
\hline
\end{tabular}




\begin{tabular}{|c|c|c|}
\hline Jezebel & 1938 & Jezebel - Die boshafte Lady \\
\hline Ninotchka & 1939 & Ninotchka \\
\hline Fantasia & 1940 & Fantasia \\
\hline Pinocchio & 1940 & Pinocchio \\
\hline Rebecca & 1940 & Rebecca \\
\hline Sergeant York & 1941 & Sergeant York \\
\hline Dumbo & 1941 & Dumbo, der fliegende Elefant \\
\hline Yankee Doodle Dandy & 1942 & Yankee Doodle Dandy \\
\hline Casablanca & 1942 & Casablanca \\
\hline Bambi & 1942 & Bambi \\
\hline Mrs. Miniver & 1942 & Mrs. Miniver \\
\hline Sahara & 1943 & Sahara \\
\hline Jane Eyre & 1943 & Jane Eyre - Die Waise von Lowood \\
\hline Laura & 1944 & Laura \\
\hline Meet Me in St. Louis & 1944 & Meet me in St. Louis \\
\hline Gilda & 1947 & Gilda \\
\hline Monsieur Verdoux & 1947 & Monsieur Verdoux - Der Frauenmörder von Paris \\
\hline Red River & 1948 & Red River \\
\hline Hamlet & 1948 & Hamlet \\
\hline Cinderella & 1950 & Cinderella \\
\hline Winchester '73 & 1950 & Winchester '73 \\
\hline Rio Grande & 1950 & Rio Grande \\
\hline Sunset Blvd. & 1950 & Sunset Blvd. - Boulevard der Dämmerung \\
\hline Harvey & 1950 & Mein Freund Harvey \\
\hline The African Queen & 1951 & African Queen \\
\hline Umberto $\mathrm{D}$. & 1952 & Umberto D. \\
\hline Ikiru & 1952 & Ikiru - Einmal wirklich leben \\
\hline Stalag 17 & 1953 & Stalag 17 \\
\hline Peter Pan & 1953 & Peter Pan \\
\hline Shane & 1953 & Mein großer Freund Shane \\
\hline Sabrina & 1954 & Sabrina \\
\hline Gojira & 1954 & Godzilla \\
\hline
\end{tabular}




\begin{tabular}{|c|c|c|}
\hline La strada & 1954 & La Strada - Das Lied der Straße \\
\hline The Ladykillers & 1955 & Ladykillers \\
\hline Dracula & 1958 & Dracula \\
\hline Gigi & 1958 & Gigi \\
\hline The Blob & 1958 & Blob - Schrecken ohne Namen \\
\hline Vertigo & 1958 & Vertigo - Aus dem Reich der Toten \\
\hline Hiroshima mon amour & 1959 & Hiroshima mon amour \\
\hline Ben-Hur & 1959 & Ben Hur \\
\hline Rio Bravo & 1959 & Rio Bravo \\
\hline Psycho & 1960 & Psycho \\
\hline Spartacus & 1960 & Spartacus \\
\hline West Side Story & 1961 & West Side Story \\
\hline Viridiana & 1961 & Viridiana \\
\hline Yôjinbô & 1961 & Yojimbo - Der Leibwächter \\
\hline Lolita & 1962 & Lolita \\
\hline La jetée & 1962 & La jetée - Am Rande des Rollfelds \\
\hline Dr. No & 1962 & James Bond 007 jagt Dr. No \\
\hline Cleopatra & 1963 & Cleopatra \\
\hline Charade & 1963 & Charade \\
\hline Mary Poppins & 1964 & Mary Poppins \\
\hline Marnie & 1964 & Marnie \\
\hline My Fair Lady & 1964 & My Fair Lady \\
\hline Goldfinger & 1964 & James Bond 007 - Goldfinger \\
\hline Zulu & 1964 & Zulu - Die Schlacht von Rorkes Drift \\
\hline Manos: The Hands of Fate & 1966 & Manos: The Hands of Fate \\
\hline Persona & 1966 & Persona \\
\hline Fahrenheit 451 & 1966 & Fahrenheit 451 \\
\hline Andrey Rublev & 1966 & Andrej Rubljow \\
\hline Blowup & 1966 & BlowUp - Ekstaze '67 \\
\hline Chitty Chitty Bang Bang & 1968 & Tschitti Tschitti Bäng Bäng \\
\hline Bullitt & 1968 & Bullitt \\
\hline Easy Rider & 1969 & Easy Rider \\
\hline
\end{tabular}




\begin{tabular}{|c|c|c|}
\hline The Wild Bunch & 1969 & The Wild Bunch - Sie kannten kein Gesetz \\
\hline Z & 1969 & Z - Anatomie eines politischen Mordes \\
\hline Butch Cassidy and the Sundance Kid & 1969 & Butch Cassidy und Sundance Kid - Zwei Banditen \\
\hline The AristoCats & 1970 & Aristocats \\
\hline MASH & 1970 & M.A.S.H. \\
\hline Little Big Man & 1970 & Little Big Man \\
\hline Love Story & 1970 & Love Story \\
\hline El Topo & 1970 & El Topo \\
\hline Tora! Tora! Tora! & 1970 & Tora! Tora! Tora! \\
\hline Patton & 1970 & Patton - Rebell in Uniform \\
\hline Dirty Harry & 1971 & Dirty Harry \\
\hline Harold and Maude & 1971 & Harold and Maude \\
\hline THX 1138 & 1971 & THX 1138 \\
\hline The French Connection & 1971 & French Connection - Brennpunkt Brooklyn \\
\hline Cabaret & 1972 & Cabaret \\
\hline Frenzy & 1972 & Frenzy \\
\hline Solyaris & 1972 & Solaris \\
\hline Robin Hood & 1973 & Robin Hood \\
\hline Serpico & 1973 & Serpico \\
\hline American Graffiti & 1973 & American Graffiti \\
\hline The Wicker Man & 1973 & The Wicker Man \\
\hline Papillon & 1973 & Papillon \\
\hline Chinatown & 1974 & Chinatown \\
\hline The Rocky Horror Picture Show & 1975 & The Rocky Horror Picture Show \\
\hline Barry Lyndon & 1975 & Barry Lyndon \\
\hline Sholay & 1975 & Sholay \\
\hline Taxi Driver & 1976 & Taxi Driver \\
\hline Rocky & 1976 & Rocky \\
\hline Network & 1976 & Network \\
\hline Carrie & 1976 & Carrie - Des Satans jüngste Tochter \\
\hline Eraserhead & 1977 & Eraserhead \\
\hline Suspiria & 1977 & Suspiria \\
\hline
\end{tabular}




\begin{tabular}{|c|c|c|}
\hline Grease & 1978 & Grease \\
\hline Superman & 1978 & Superman \\
\hline Halloween & 1978 & Halloween - Die Nacht des Grauens \\
\hline Dawn of the Dead & 1978 & Zombie - Dawn of the Dead \\
\hline Midnight Express & 1978 & 12 Uhr nachts - Midnight Express \\
\hline Apocalypse Now & 1979 & Apocalypse Now \\
\hline The Warriors & 1979 & Die Warriors \\
\hline Mad Max & 1979 & Mad Max \\
\hline Rocky II & 1979 & Rocky II \\
\hline Alien & 1979 & Alien - Das unheimliche Wesen aus einer fremden Welt \\
\hline Moonraker & 1979 & James Bond 007 - Moonraker - Streng geheim \\
\hline Superman II & 1980 & Superman 2 \\
\hline Caddyshack & 1980 & Caddyshack - Wahnsinn ohne Handicap \\
\hline Superman II & 1980 & Superman II - Allein gegen alle \\
\hline The Shining & 1980 & Shining \\
\hline The Blues Brothers & 1980 & Blues Brothers \\
\hline Mad Max 2 & 1981 & Mad Max II - Der Vollstrecker \\
\hline Halloween II & 1981 & Halloween II - Das Grauen kehrt zurück \\
\hline An American Werewolf in London & 1981 & American Werewolf \\
\hline Blade Runner & 1982 & Blade Runner \\
\hline Poltergeist & 1982 & Poltergeist \\
\hline TRON & 1982 & Tron \\
\hline Gandhi & 1982 & Gandhi \\
\hline Rocky III & 1982 & Rocky III - Das Auge des Tigers \\
\hline Scarface & 1983 & Scarface \\
\hline Videodrome & 1983 & Videodrome \\
\hline Octopussy & 1983 & James Bond 007 - Octopussy \\
\hline WarGames & 1983 & WarGames - Kriegsspiele \\
\hline This Is Spinal Tap & 1984 & This Is Spinal Tap \\
\hline Ghostbusters & 1984 & Ghostbusters - Die Geisterjäger \\
\hline Gremlins & 1984 & Gremlins - Kleine Monster \\
\hline Beverly Hills Cop & 1984 & Beverly Hills Cop - Ich Iös' den Fall auf jeden Fall \\
\hline
\end{tabular}




\begin{tabular}{|c|c|c|}
\hline The Karate Kid & 1984 & Karate Kid \\
\hline The Terminator & 1984 & Terminator \\
\hline Brazil & 1985 & Brazil \\
\hline Ran & 1985 & Ran \\
\hline Rocky IV & 1985 & Rocky IV - Der Kampf des Jahrhunderts \\
\hline The Breakfast Club & 1985 & Breakfast Club - Der Frühstücksclub \\
\hline Platoon & 1986 & Platoon \\
\hline Blue Velvet & 1986 & Blue Velvet \\
\hline Aliens & 1986 & Aliens - Die Rückkehr \\
\hline Stand by Me & 1986 & Stand by Me - Das Geheimnis eines Sommers \\
\hline Top Gun & 1986 & Top Gun - Sie fürchten weder Tod noch Teufel \\
\hline Highlander & 1986 & Highlander - Es kann nur einen geben \\
\hline RoboCop & 1987 & RoboCop \\
\hline Full Metal Jacket & 1987 & Full Metal Jacket \\
\hline Predator & 1987 & Predator \\
\hline Dirty Dancing & 1987 & Dirty Dancing \\
\hline Spaceballs & 1987 & Spaceballs \\
\hline Wall Street & 1987 & Wall Street \\
\hline The Untouchables & 1987 & The Untouchables - Die Unbestechlichen \\
\hline Lethal Weapon & 1987 & Lethal Weapon - Zwei stahlharte Profis \\
\hline Rain Man & 1988 & Rain Man \\
\hline Big & 1988 & Big \\
\hline Beetlejuice & 1988 & Beetlejuice \\
\hline Nuovo Cinema Paradiso & 1988 & Cinema paradiso \\
\hline Ghostbusters II & 1989 & Ghostbusters 2 \\
\hline The Abyss & 1989 & The Abyss \\
\hline Batman & 1989 & Batman \\
\hline Lethal Weapon 2 & 1989 & Lethal Weapon 2 - Brennpunkt L.A. \\
\hline Pretty Woman & 1990 & Pretty Woman \\
\hline Total Recall & 1990 & Die totale Erinnerung - Total Recall \\
\hline Ghost & 1990 & Ghost - Nachricht von Sam \\
\hline Goodfellas & 1990 & GoodFellas - Drei Jahrzehnte in der Mafia \\
\hline
\end{tabular}




\begin{tabular}{|c|c|c|}
\hline Hook & 1991 & Hook \\
\hline Thelma \& Louise & 1991 & Thelma \& Louise \\
\hline JFK & 1991 & JFK - Tatort Dallas \\
\hline The Addams Family & 1991 & Die Addams Family \\
\hline Reservoir Dogs & 1992 & Reservoir Dogs \\
\hline Aladdin & 1992 & Aladdin \\
\hline Alien ${ }^{3}$ & 1992 & Alien $^{3}$ \\
\hline Basic Instinct & 1992 & Basic Instinct \\
\hline Dracula & 1992 & Bram Stoker's Dracula \\
\hline True Romance & 1993 & True Romance \\
\hline Jurassic Park & 1993 & Jurassic Park \\
\hline Philadelphia & 1993 & Philadelphia \\
\hline Mrs. Doubtfire & 1993 & Mrs. Doubtfire - Das stachelige Kindermädchen \\
\hline Clerks & 1993 & Clerks - Die Ladenhüter \\
\hline The Nightmare Before Christmas & 1993 & Nightmare Before Christmas \\
\hline Pulp Fiction & 1994 & Pulp Fiction \\
\hline Forrest Gump & 1994 & Forrest Gump \\
\hline Speed & 1994 & Speed \\
\hline Léon & 1994 & Léon - Der Profi \\
\hline Braveheart & 1995 & Braveheart \\
\hline Toy Story & 1995 & Toy Story \\
\hline Heat & 1995 & Heat \\
\hline Casino & 1995 & Casino \\
\hline Apollo 13 & 1995 & Apollo 13 \\
\hline Jumanji & 1995 & Jumanji \\
\hline Twelve Monkeys & 1995 & 12 Monkeys \\
\hline Fargo & 1996 & Fargo \\
\hline Independence Day & 1996 & Independence Day \\
\hline Mission: Impossible & 1996 & Mission: Impossible \\
\hline From Dusk Till Dawn & 1996 & From Dusk Till Dawn \\
\hline Mars Attacks! & 1996 & Mars Attacks! \\
\hline Trainspotting & 1996 & Trainspotting - Neue Helden \\
\hline
\end{tabular}




\begin{tabular}{|c|c|c|}
\hline The Rock & 1996 & The Rock - Fels der Entscheidung \\
\hline Scream & 1996 & Scream - Schrei! \\
\hline Jerry Maguire & 1996 & Jerry Maguire - Spiel des Lebens \\
\hline Romeo + Juliet & 1996 & William Shakespeares Romeo + Julia \\
\hline Titanic & 1997 & Titanic \\
\hline Good Will Hunting & 1997 & Good Will Hunting \\
\hline L.A. Confidential & 1997 & L.A. Confidential \\
\hline Men in Black & 1997 & Men in Black \\
\hline The Game & 1997 & The Game \\
\hline American History $\mathrm{X}$ & 1998 & American History $\mathrm{X}$ \\
\hline The Big Lebowski & 1998 & The Big Lebowski \\
\hline Fear and Loathing in Las Vegas & 1998 & Fear and Loathing in Las Vegas \\
\hline Blade & 1998 & Blade \\
\hline Armageddon & 1998 & Armageddon - Das jüngste Gericht \\
\hline Fight Club & 1999 & Fight Club \\
\hline American Beauty & 1999 & American Beauty \\
\hline The Green Mile & 1999 & The Green Mile \\
\hline The Sixth Sense & 1999 & The Sixth Sense \\
\hline Toy Story 2 & 1999 & Toy Story 2 \\
\hline Sleepy Hollow & 1999 & Sleepy Hollow \\
\hline American Pie & 1999 & American Pie - Wie ein heißer Apfelkuchen \\
\hline The Matrix & 1999 & Matrix \\
\hline Requiem for a Dream & 2000 & Requiem for a Dream \\
\hline American Psycho & 2000 & American Psycho \\
\hline Mission: Impossible II & 2000 & Mission: Impossible 2 \\
\hline Snatch & 2000 & Snatch - Schweine und Diamanten \\
\hline X-Men & 2000 & X-Men - Der Film \\
\hline Cast Away & 2000 & Cast Away - Verschollen \\
\hline Unbreakable & 2000 & Unbreakable - Unzerbrechlich \\
\hline Donnie Darko & 2001 & Donnie Darko \\
\hline Ocean's Eleven & 2001 & Ocean's Eleven \\
\hline Training Day & 2001 & Training Day \\
\hline
\end{tabular}




\begin{tabular}{|c|c|c|}
\hline Gladiator & 2001 & Gladiator \\
\hline Memento & 2001 & Memento \\
\hline A Beautiful Mind & 2001 & A Beautiful Mind - Genie und Wahnsinn \\
\hline Shrek & 2001 & Shrek - Der tollkühne Held \\
\hline Spider-Man & 2002 & Spider-Man \\
\hline Catch Me If You Can & 2002 & Catch Me If You Can \\
\hline Minority Report & 2002 & Minority Report \\
\hline Ice Age & 2002 & Ice Age \\
\hline Kill Bill: Vol. 1 & 2003 & Kill Bill: Volume 1 \\
\hline Big Fish & 2003 & Big Fish \\
\hline Mystic River & 2003 & Mystic River \\
\hline X-Men 2 & 2003 & X-Men 2 \\
\hline The Matrix Reloaded & 2003 & Matrix Reloaded \\
\hline The Matrix Revolutions & 2003 & Matrix Revolutions \\
\hline Kill Bill: Vol. 2 & 2004 & Kill Bill - Volume 2 \\
\hline Million Dollar Baby & 2004 & Million Dollar Baby \\
\hline Spider-Man 2 & 2004 & Spider-Man 2 \\
\hline Shaun of the Dead & 2004 & Shaun of the Dead \\
\hline I, Robot & 2004 & I, Robot \\
\hline The Incredibles & 2004 & Die Unglaublichen - The Incredibles \\
\hline Batman Begins & 2005 & Batman Begins \\
\hline Sin City & 2005 & Sin City \\
\hline Mr. \& Mrs. Smith & 2005 & Mr. \& Mrs. Smith \\
\hline King Kong & 2005 & King Kong \\
\hline 300 & 2006 & 300 \\
\hline Blood Diamond & 2006 & Blood Diamond \\
\hline Children of Men & 2006 & Children of Men \\
\hline Little Miss Sunshine & 2006 & Little Miss Sunshine \\
\hline The Departed & 2006 & Departed - Unter Feinden \\
\hline Casino Royale & 2006 & James Bond 007 - Casino Royale \\
\hline The Prestige & 2006 & Prestige - Die Meister der Magie \\
\hline Pirates of the Caribbean: Dead Man's Chest & 2006 & Pirates of the Caribbean - Fluch der Karibik 2 \\
\hline
\end{tabular}




\begin{tabular}{|c|c|c|}
\hline No Country for Old Men & 2007 & No Country for Old Men \\
\hline I Am Legend & 2007 & I Am Legend \\
\hline Transformers & 2007 & Transformers \\
\hline Ratatouille & 2007 & Ratatouille \\
\hline Into the Wild & 2007 & Into the Wild \\
\hline Superbad & 2007 & Superbad \\
\hline Juno & 2007 & Juno \\
\hline Spider-Man 3 & 2007 & Spider-Man 3 \\
\hline The Dark Knight & 2008 & The Dark Knight \\
\hline Iron Man & 2008 & Iron Man \\
\hline Gran Torino & 2008 & Gran Torino \\
\hline Hancock & 2008 & Hancock \\
\hline WALL·E & 2008 & WALL·E - Der Letzte räumt die Erde auf \\
\hline Twilight & 2008 & Twilight - Biss zum Morgengrauen \\
\hline Inglourious Basterds & 2009 & Inglourious Basterds \\
\hline Star Trek & 2009 & Star Trek \\
\hline Sherlock Holmes & 2009 & Sherlock Holmes \\
\hline Zombieland & 2009 & Zombieland \\
\hline (500) Days of Summer & 2009 & (500) Days of Summer \\
\hline Avatar & 2009 & Avatar - Aufbruch nach Pandora \\
\hline Watchmen & 2009 & Watchmen - Die Wächter \\
\hline The Hangover & 2009 & Hangover \\
\hline The District 9 & 2009 & District 9 \\
\hline Inception & 2010 & Inception \\
\hline Shutter Island & 2010 & Shutter Island \\
\hline Black Swan & 2010 & Black Swan \\
\hline Toy Story 3 & 2010 & Toy Story 3 \\
\hline Iron Man 2 & 2010 & Iron Man 2 \\
\hline The Social Network & 2010 & The Social Network \\
\hline Kick-Ass & 2010 & Kick-Ass \\
\hline The King's Speech & 2010 & The King's Speech - Die Rede des Königs \\
\hline Thor & 2011 & Thor \\
\hline
\end{tabular}




\begin{tabular}{|c|c|c|}
\hline Captain America: The First Avenger & 2011 & Captain America - The First Avenger \\
\hline Drive & 2011 & Drive \\
\hline Source Code & 2011 & Source Code \\
\hline The Hangover Part II & 2011 & Hangover 2 \\
\hline The Dark Knight Rises & 2012 & The Dark Knight Rises \\
\hline The Avengers & 2012 & The Avengers \\
\hline Django Unchained & 2012 & Django Unchained \\
\hline Ted & 2012 & Ted \\
\hline Argo & 2012 & Argo \\
\hline Skyfall & 2012 & James Bond 007 - Skyfall \\
\hline Prometheus & 2012 & Prometheus - Dunkle Zeichen \\
\hline The Hunger Games & 2012 & Die Tribute von Panem - The Hunger Games \\
\hline Silver Linings Playbook & 2012 & Silver Linings \\
\hline The Wolf of Wall Street & 2013 & The Wolf of Wall Street \\
\hline Gravity & 2013 & Gravity \\
\hline Iron Man Three & 2013 & Iron Man 3 \\
\hline Man of Steel & 2013 & Man of Steel \\
\hline World War Z & 2013 & World War Z \\
\hline 12 Years a Slave & 2013 & 12 Years a Slave \\
\hline Now You See Me & 2013 & Die Unfassbaren - Now You See Me \\
\hline The Hunger Games: Catching Fire & 2013 & Die Tribute von Panem - Catching Fire \\
\hline Interstellar & 2014 & Interstellar \\
\hline Guardians of the Galaxy & 2014 & Guardians of the Galaxy \\
\hline Edge of Tomorrow & 2014 & Edge of Tomorrow \\
\hline Whiplash & 2014 & Whiplash \\
\hline Kingsman: The Secret Service & 2014 & Kingsman: The Secret Service \\
\hline Gone Girl & 2014 & Gone Girl - Das perfekte Opfer \\
\hline The Imitation Game & 2014 & The Imitation Game - Ein streng geheimes Leben \\
\hline X-Men: Days of Future Past & 2014 & X-Men: Zukunft ist Vergangenheit \\
\hline Mad Max: Fury Road & 2015 & Mad Max: Fury Road \\
\hline Avengers: Age of Ultron & 2015 & Avengers: Age of Ultron \\
\hline Jurassic World & 2015 & Jurassic World \\
\hline
\end{tabular}




\begin{tabular}{|l|l|l|}
\hline Ant-Man & 2015 & Ant-Man \\
\hline The Hateful Eight & 2015 & The Hateful 8 \\
\hline Ex Machina & 2015 & Ex Machina \\
\hline The Revenant & 2015 & The Revenant - Der Rückkehrer \\
\hline Deadpool & 2016 & Deadpool \\
\hline Batman v Superman: Dawn of Justice & 2016 & Batman v Superman: Dawn of Justice \\
\hline Suicide Squad & 2016 & Suicide Squad \\
\hline Arrival & 2016 & Arrival \\
\hline Rogue One: A Star Wars Story & 2016 & Rogue One: A Star Wars Story \\
\hline Doctor Strange & 2016 & Doctor Strange \\
\hline X-Men: Apocalypse & 2016 & X-Men: Apocalypse \\
\hline La La Land & 2016 & La La Land \\
\hline Captain America: Civil War & 2016 & The First Avenger: Civil War \\
\hline Wonder Woman & 2017 & Wonder Woman \\
\hline Guardians of the Galaxy Vol. 2 & 2017 & Guardians of the Galaxy Vol. 2 \\
\hline Dunkirk & 2017 & Dunkirk \\
\hline Spider-Man: Homecoming & 2017 & Spider-Man: Homecoming \\
\hline Baby Driver & 2017 & Baby Driver \\
\hline Get Out & 2017 & Get Out \\
\hline Logan & 2017 & Logan - The Wolverine \\
\hline
\end{tabular}

\subsection{CTTS}

Mr. Smith Goes to Washington

1939 Mr. Smith geht nach Washington

The Lost World: Jurassic Park 1997 Vergessene Welt - Jurassic Park

Star Wars: Episode I - The Phantom Menace Star Wars: Episode II - Attack of the Clones Star Wars: Episode III - Revenge of the Sith X-Men: The Last Stand

Pirates of the Caribbean: At World's End

1999 Star Wars: Episode I - Die dunkle Bedrohung

2002 Star Wars: Episode II - Angriff der Klonkrieger

2005 Star Wars: Episode III - Die Rache der Sith

2006 X-Men: Der letzte Widerstand

2007 Pirates of the Caribbean - Am Ende der Welt 
Slumdog Millionaire

Star Wars: Episode VII - The Force Awakens
2008 Slumdog Millionär

2015 Star Wars: Episode VII - Das Erwachen der Macht 


\section{Appendix 2}

Translation strategies in the Croatian subcorpus

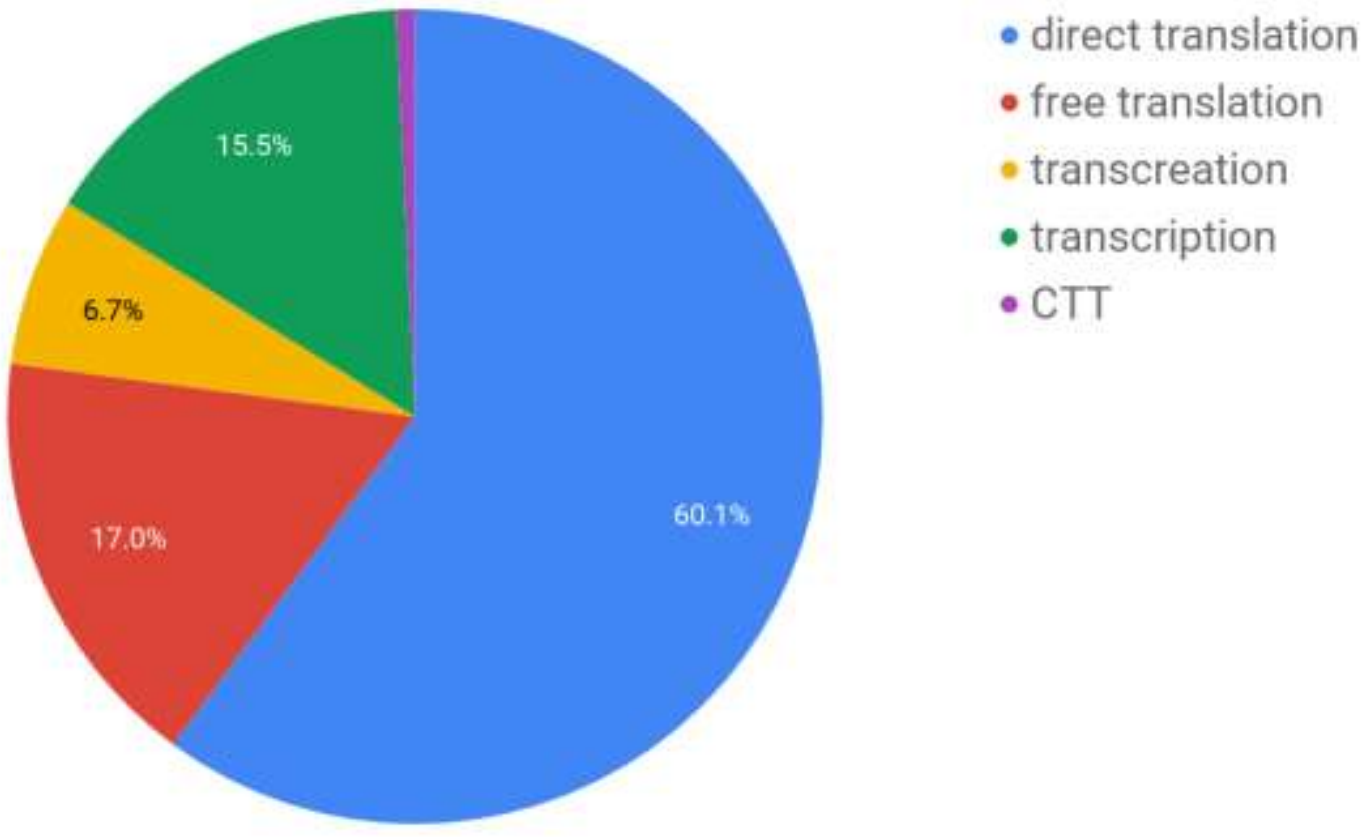

Graph 1

Translation strategies in the German subcorpus

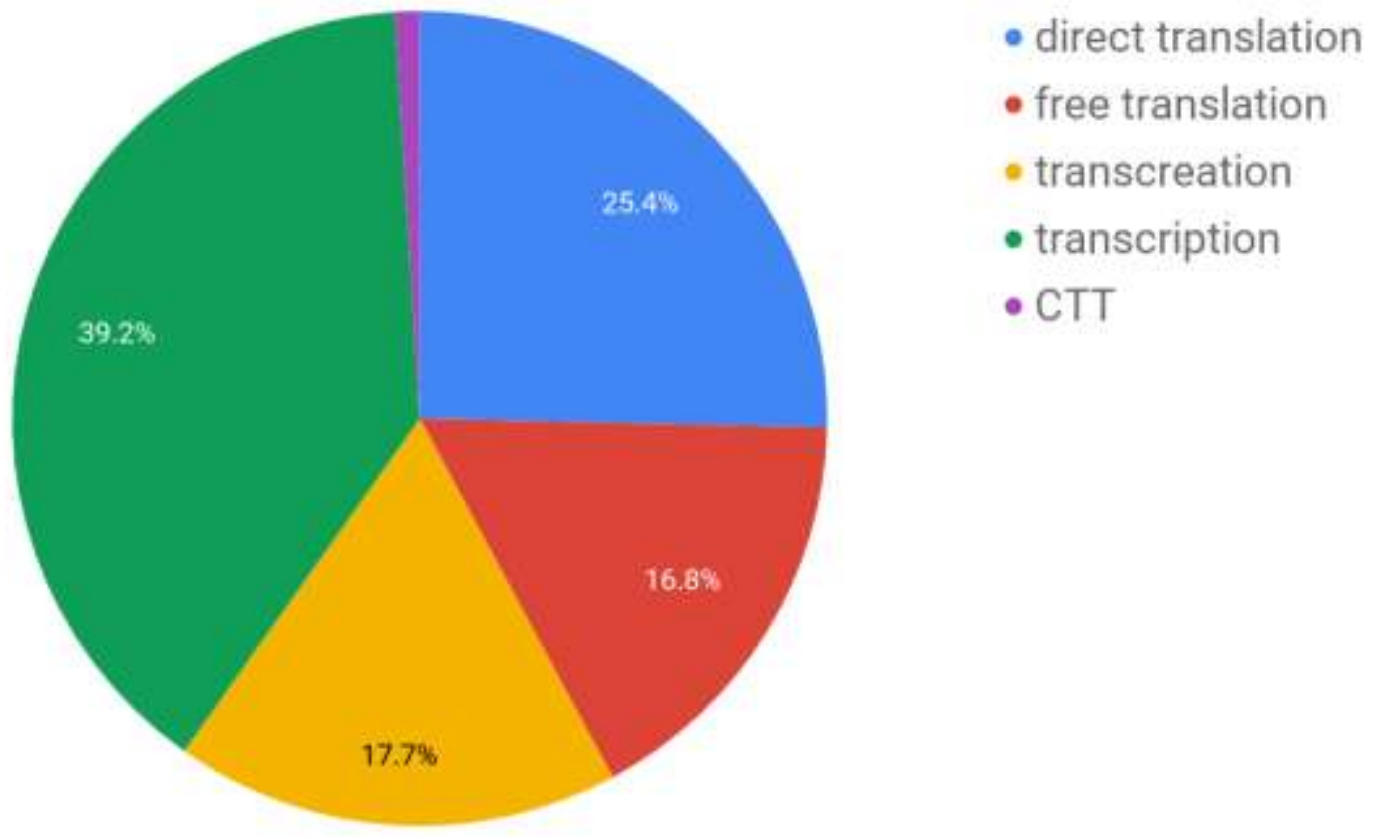

Graph 2 
Free translations in the Croatian subcorpus

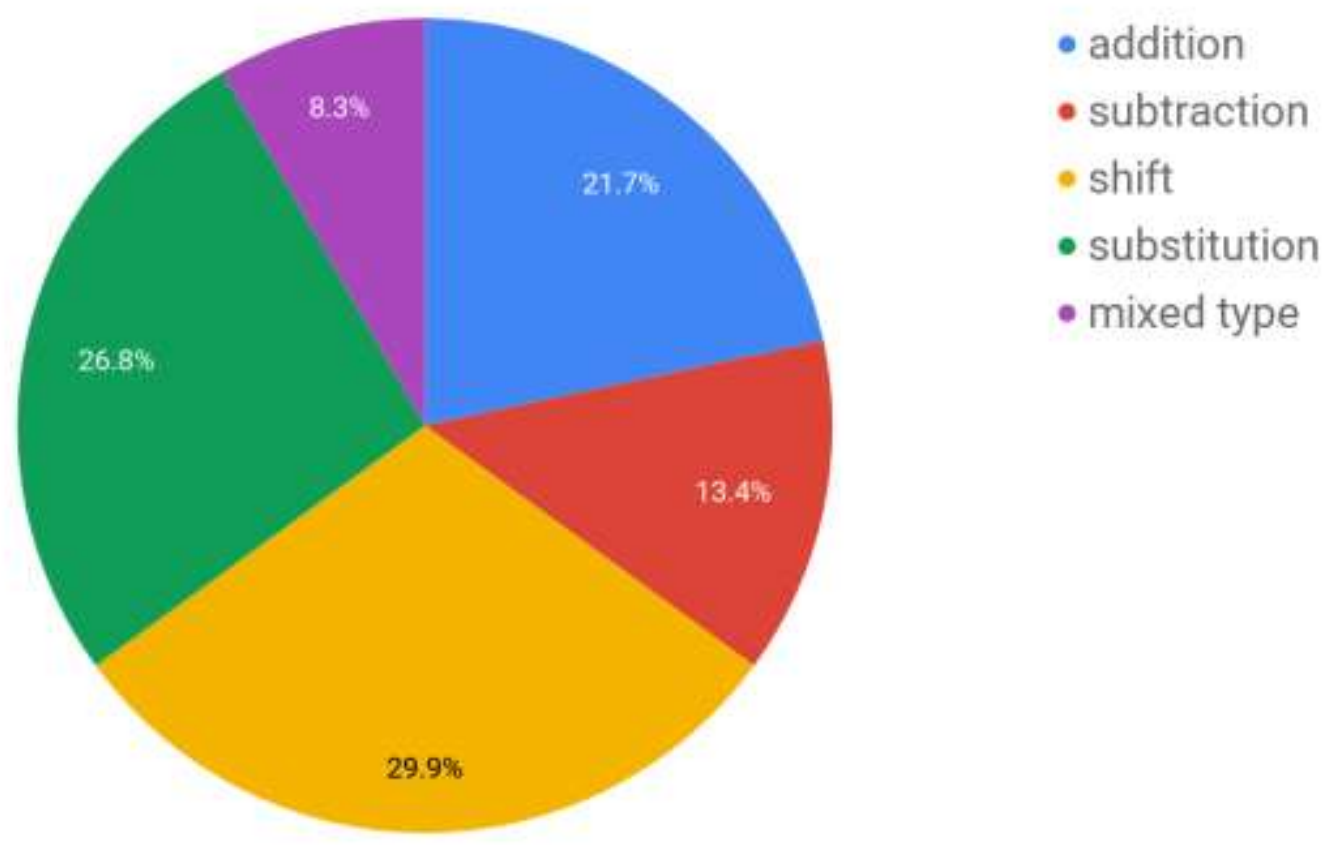

\section{Graph 3}

Transcriptions in the Croatian subcorpus

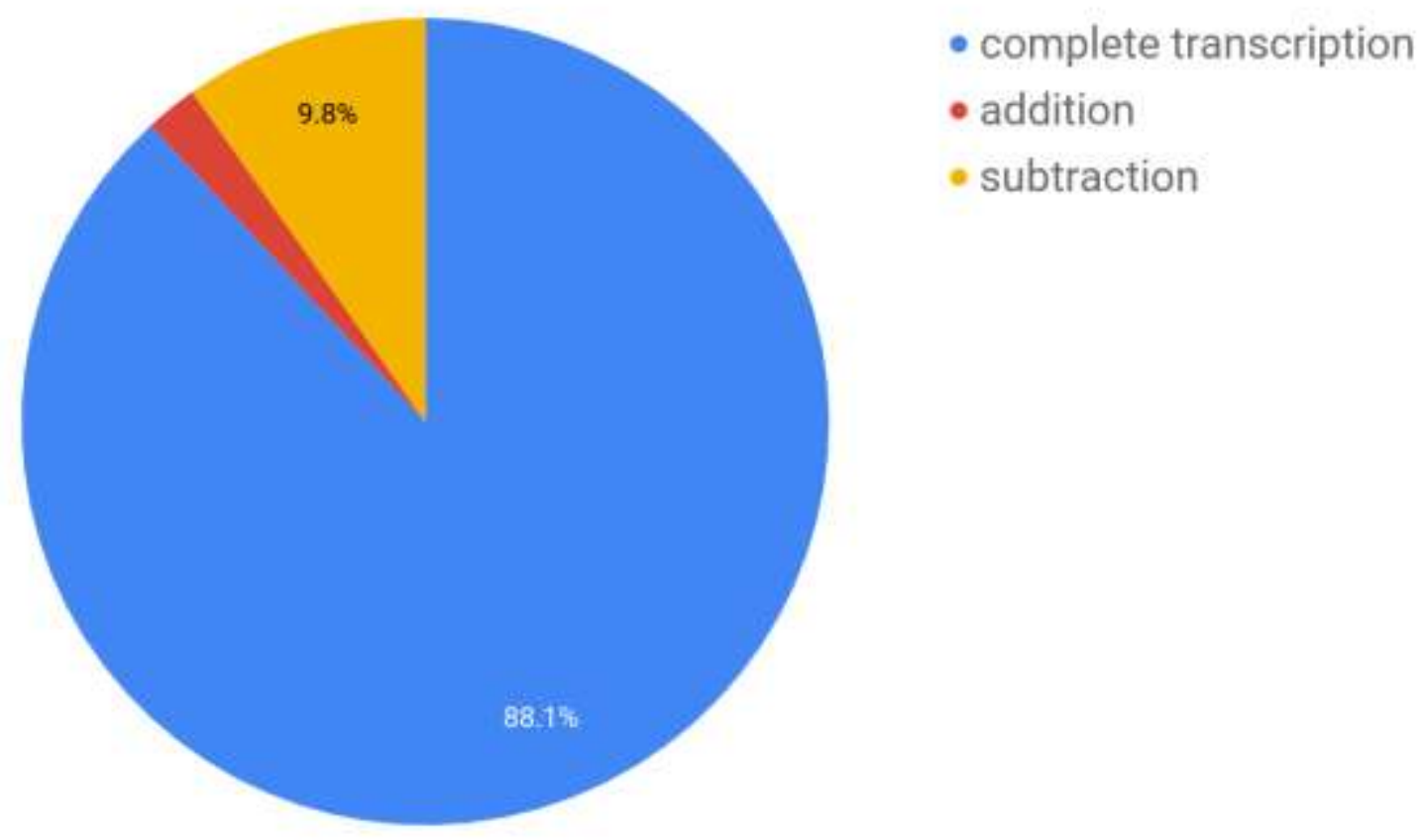

Graph 4 
Free translations in the German subcorpus

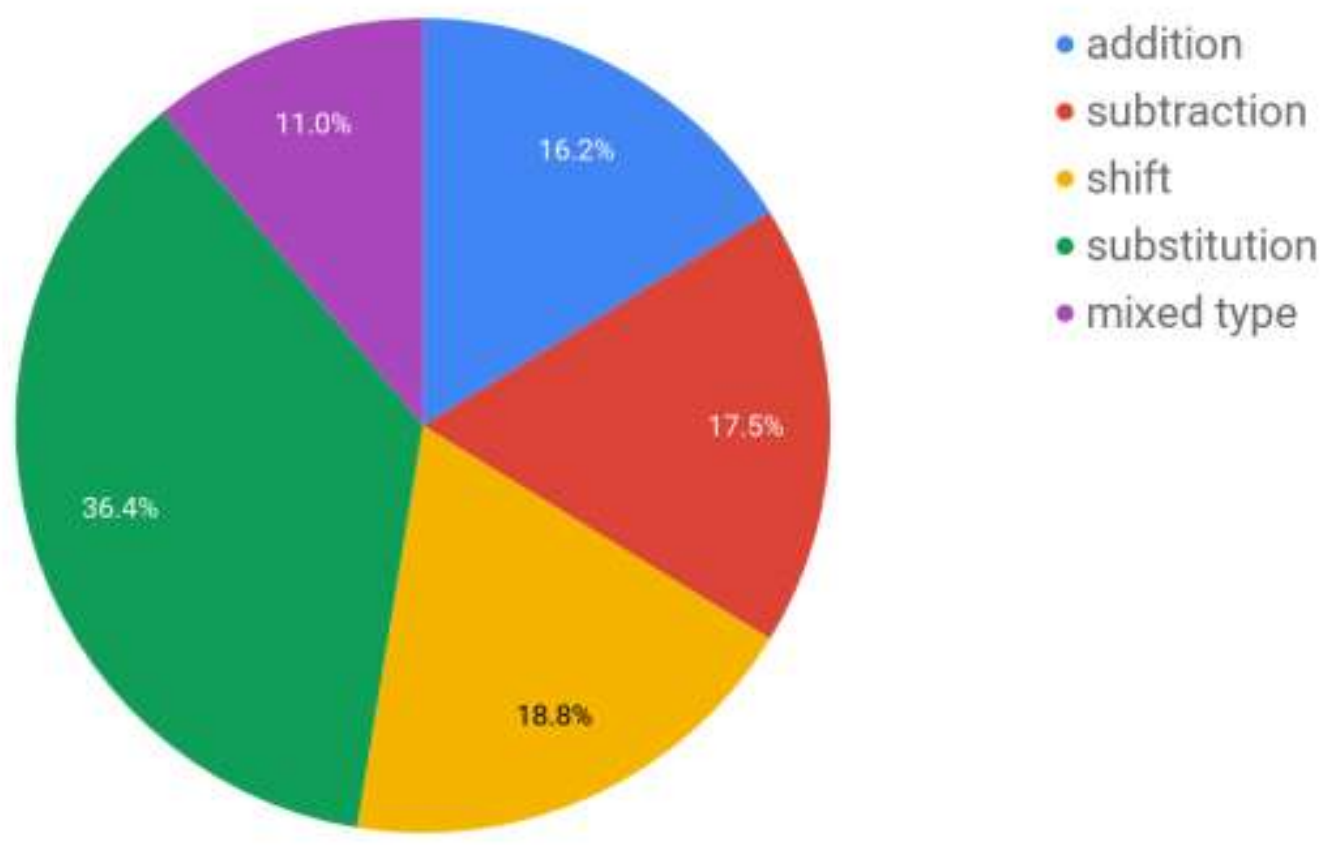

\section{Graph 5}

Transcriptions in the Croatian subcorpus

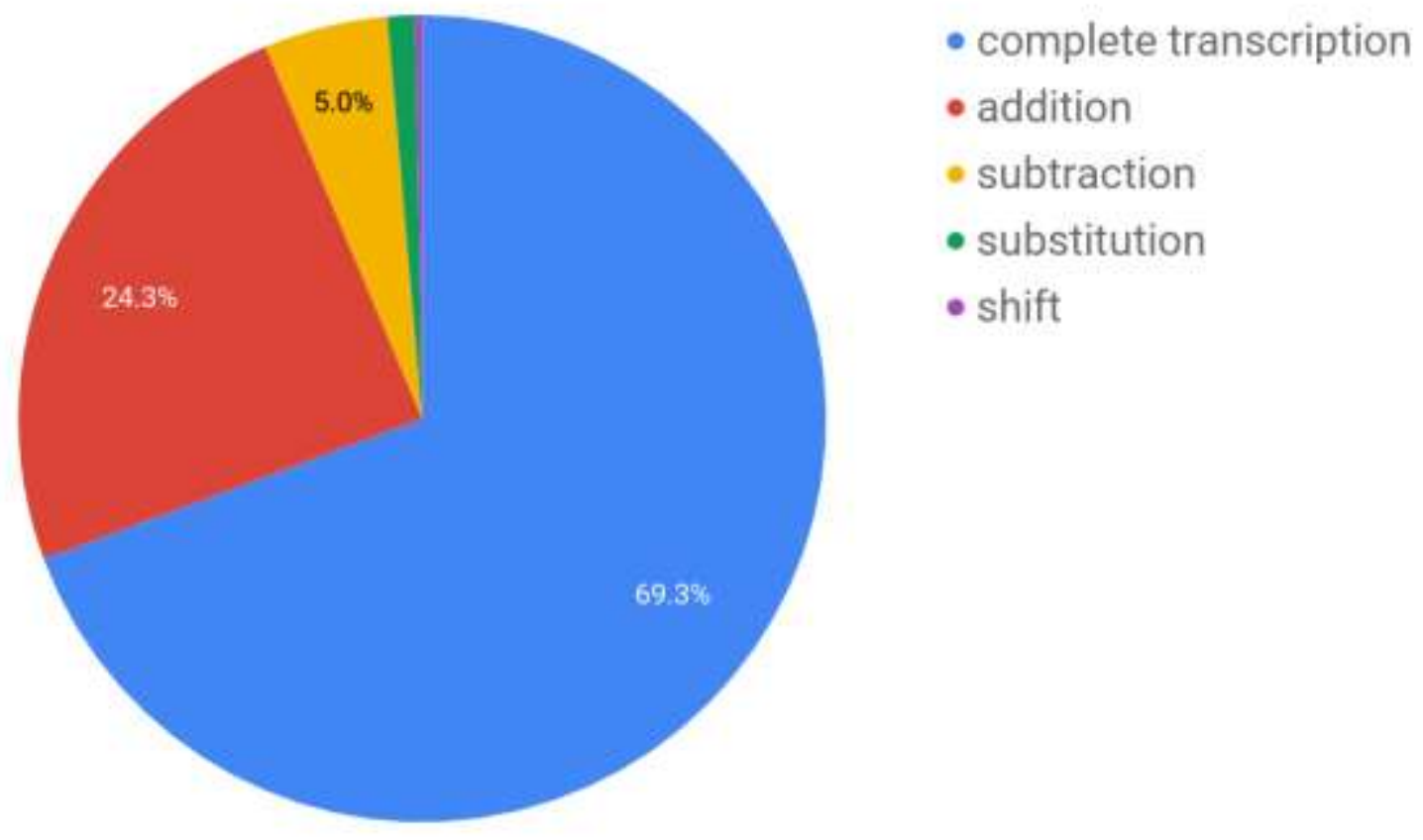

Graph 6 
Croatian translations, 1928-1937

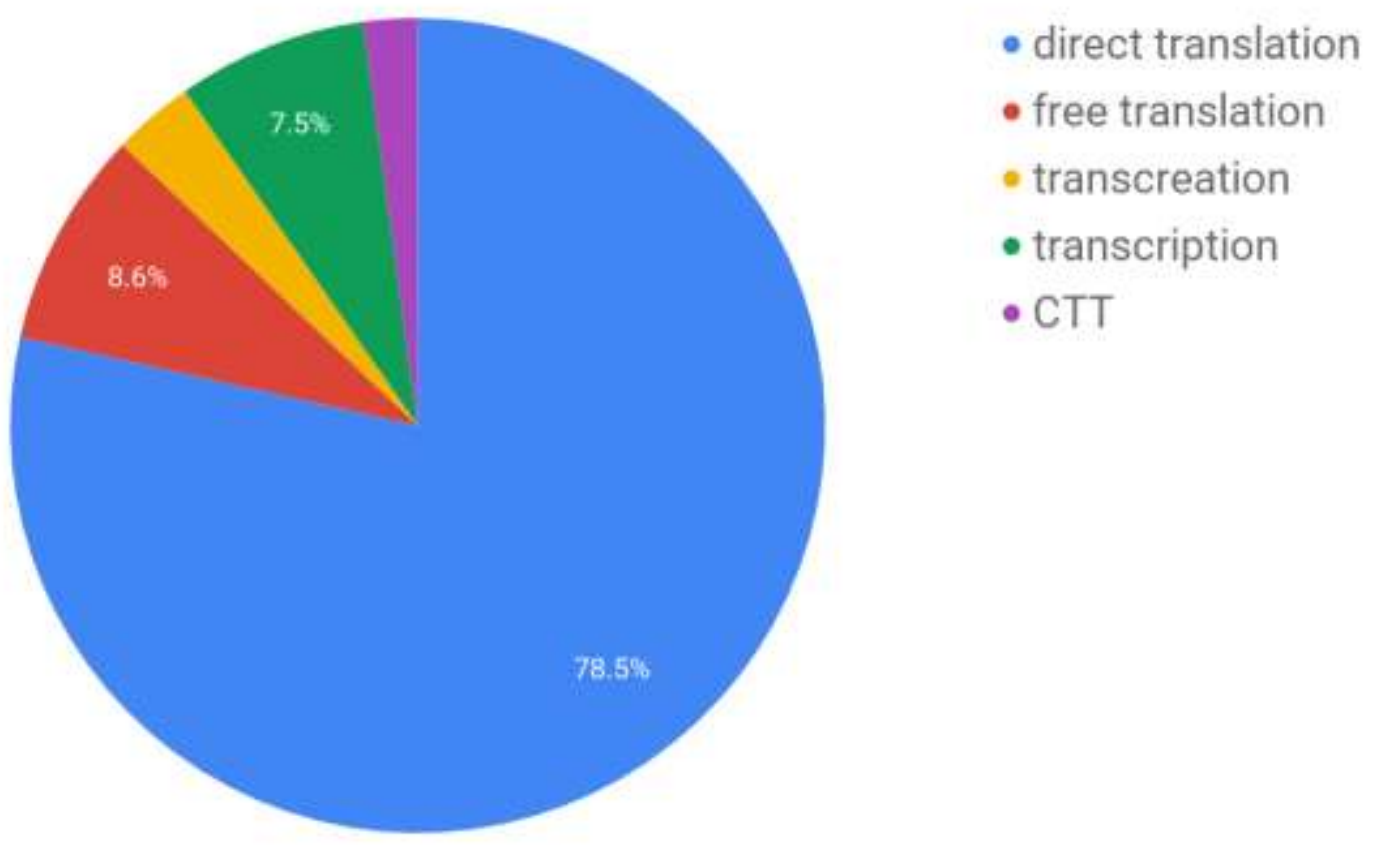

\section{Graph 7}

Croatian translations, 1938-1947

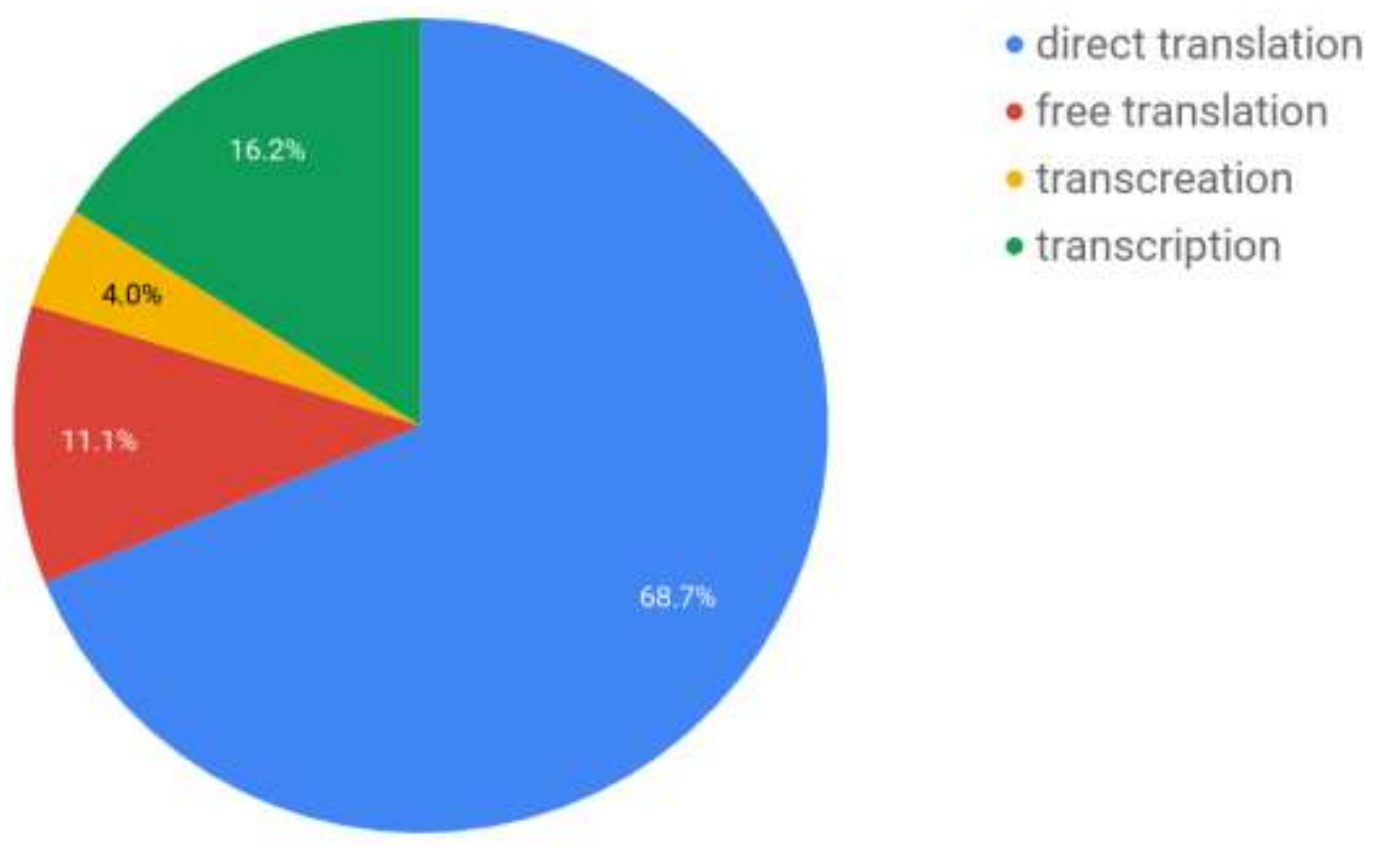

Graph 8 
Croatian translations, 1948-1957

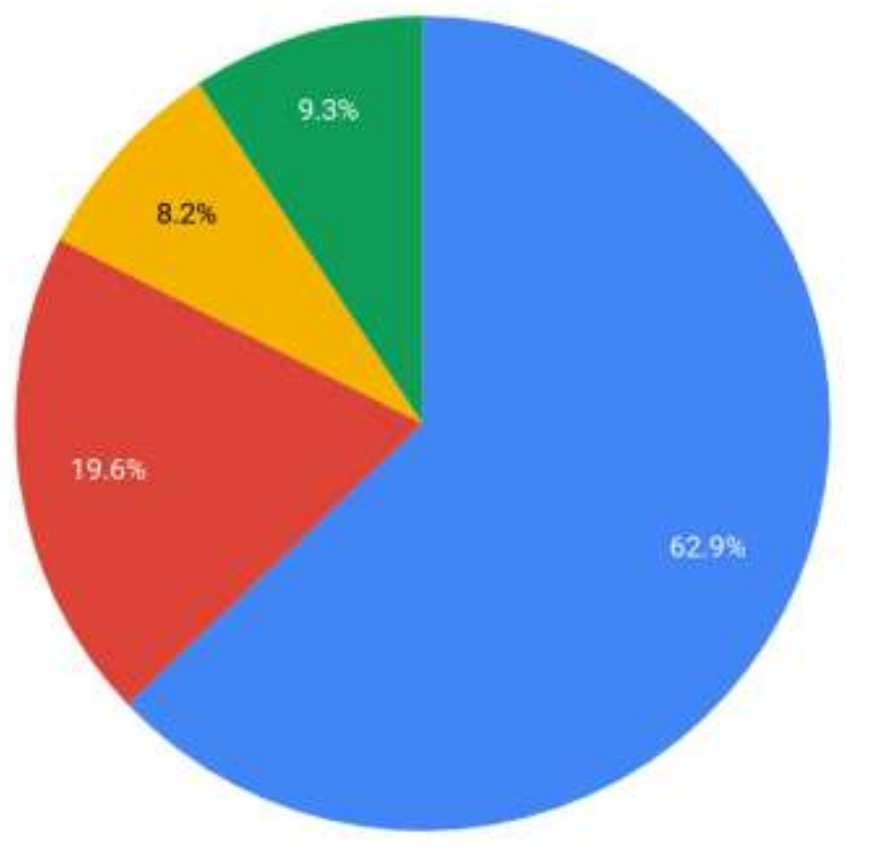

- direct translation

- free translation

- transcreation

- transcription

\section{Graph 9}

Croatian translations, 1958-1967

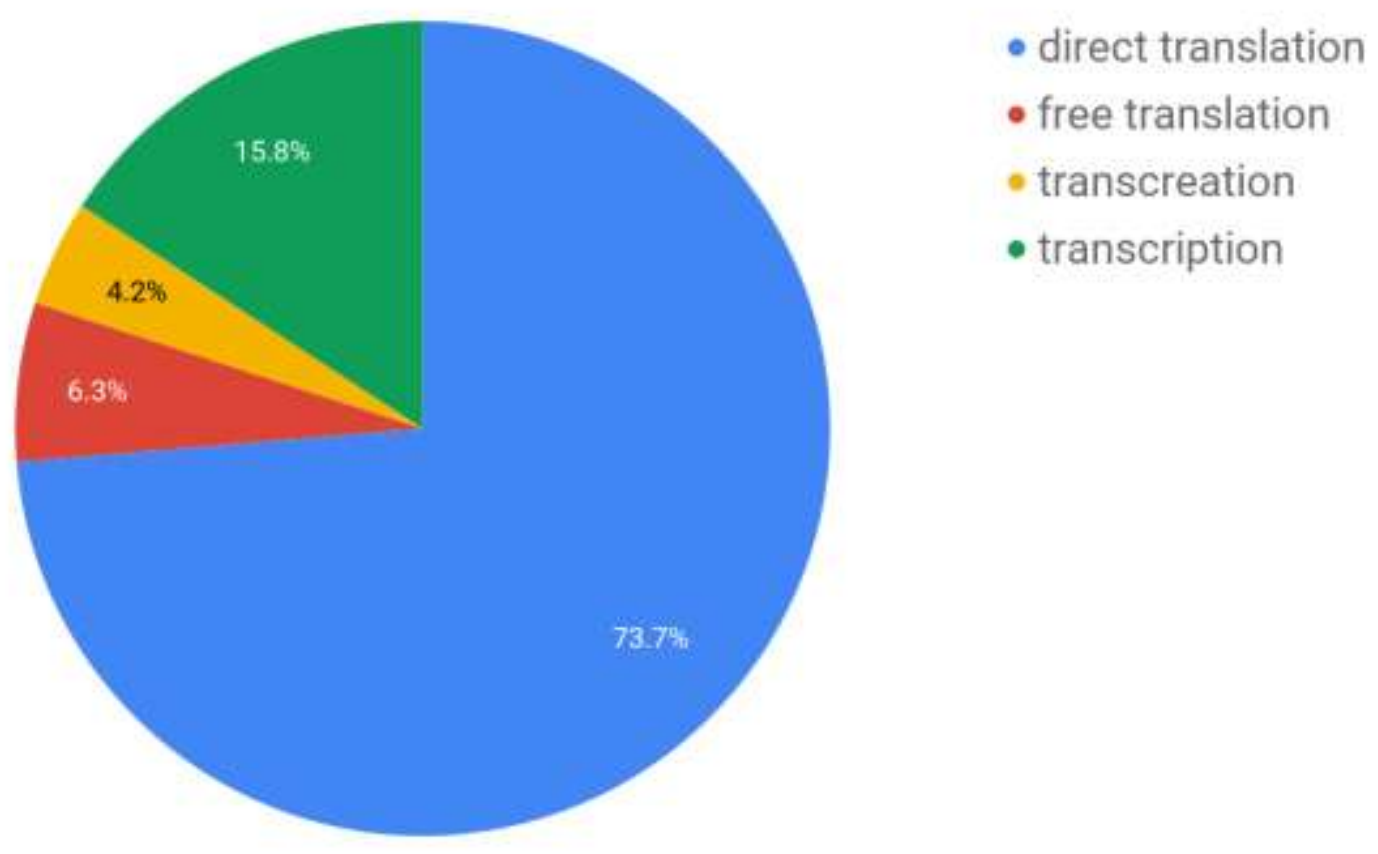

Graph 10 
Croatian translations, 1968-1977

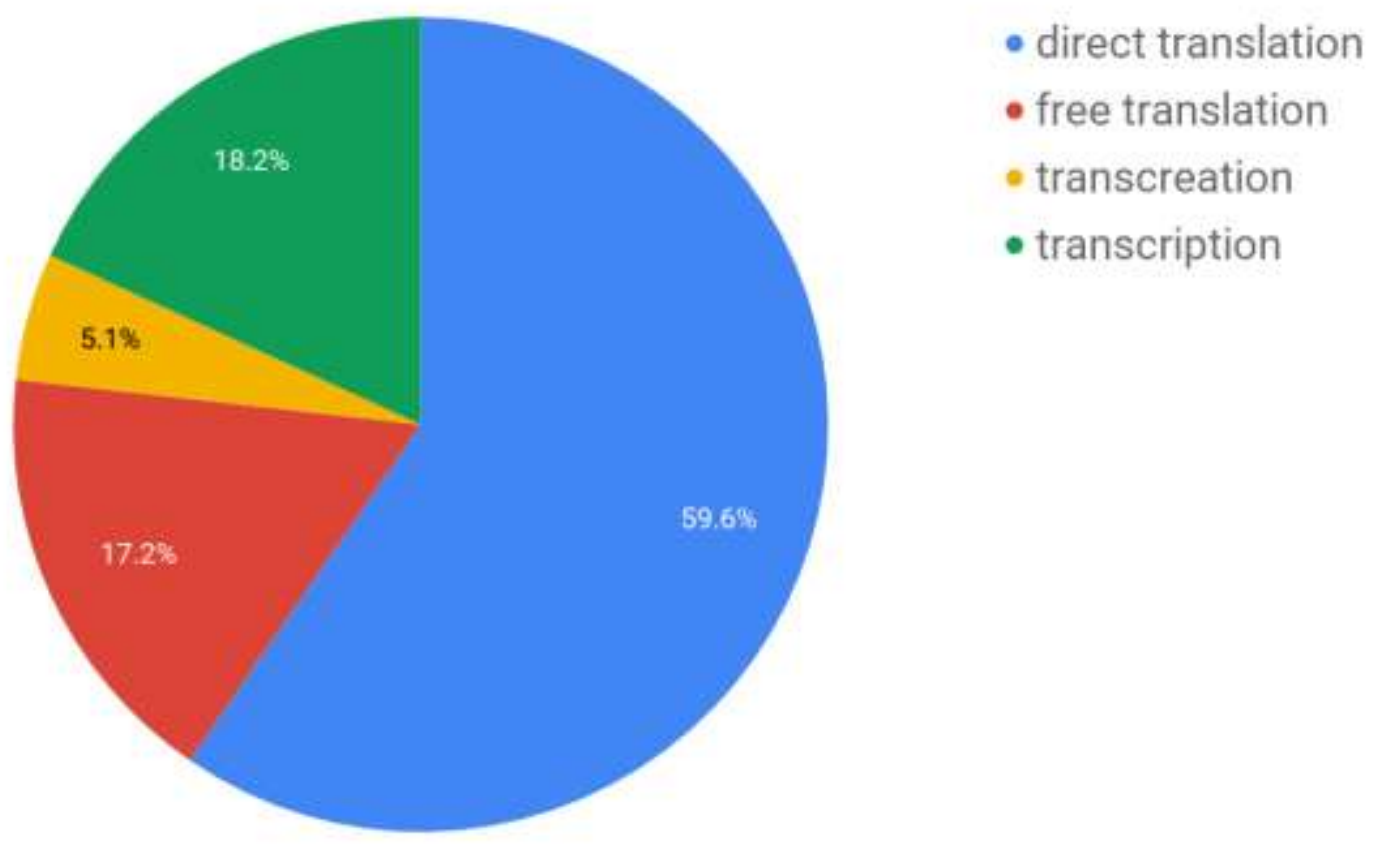

Graph 11

Croatian translations, 1978-1987

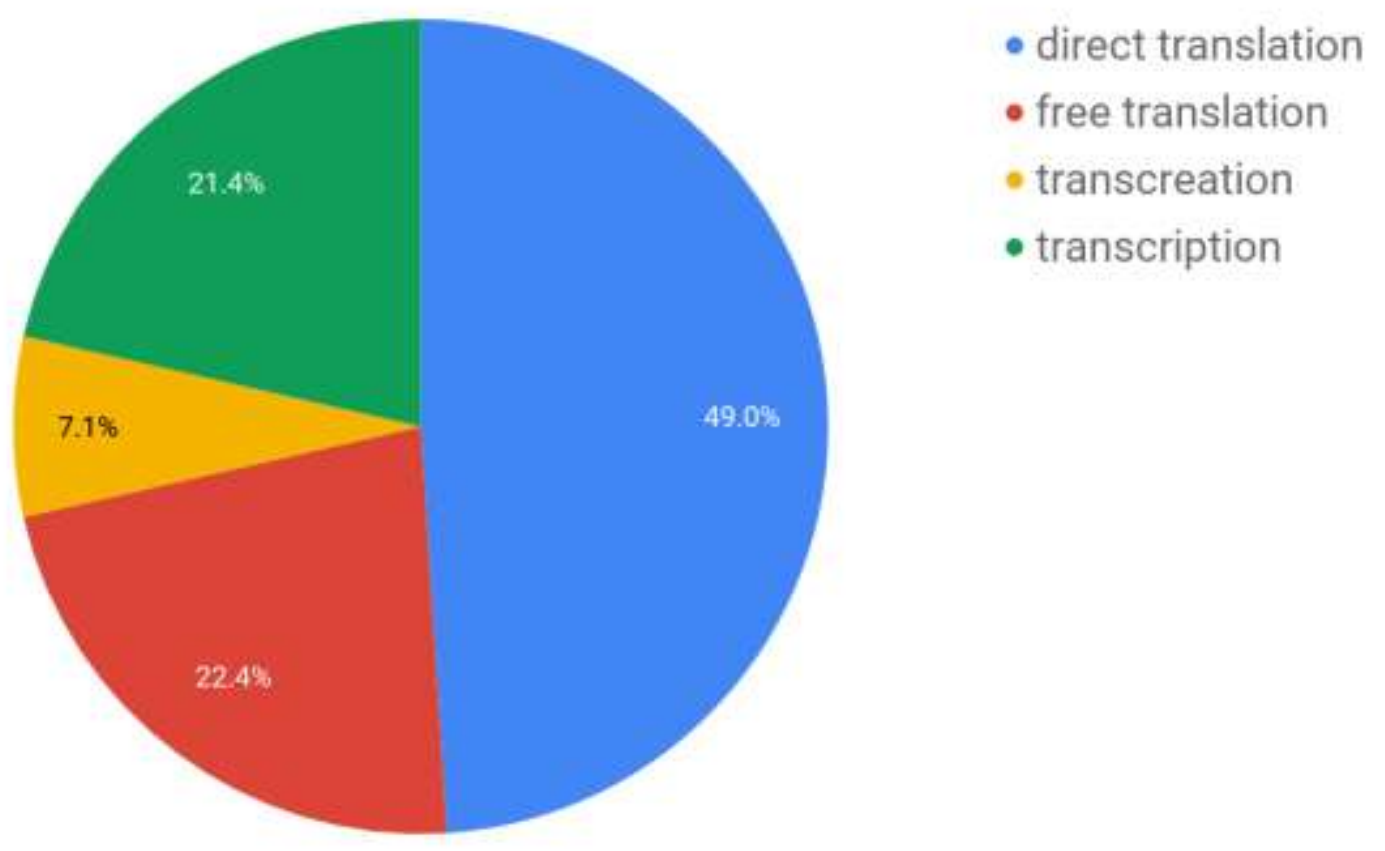

Graph 12 
Croatian translations, 1988-1997

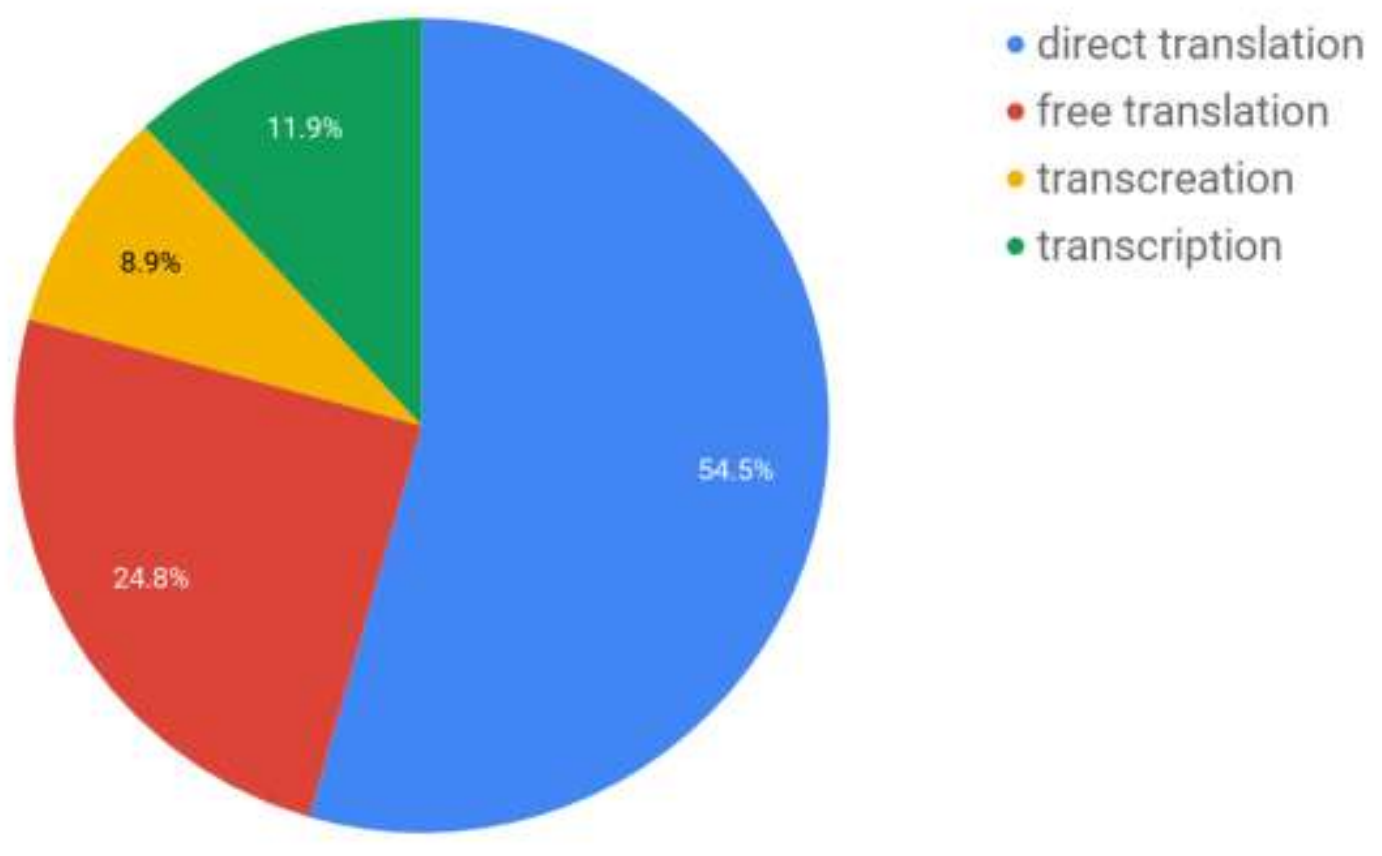

Graph 13

Croatian translations, 1998-2007

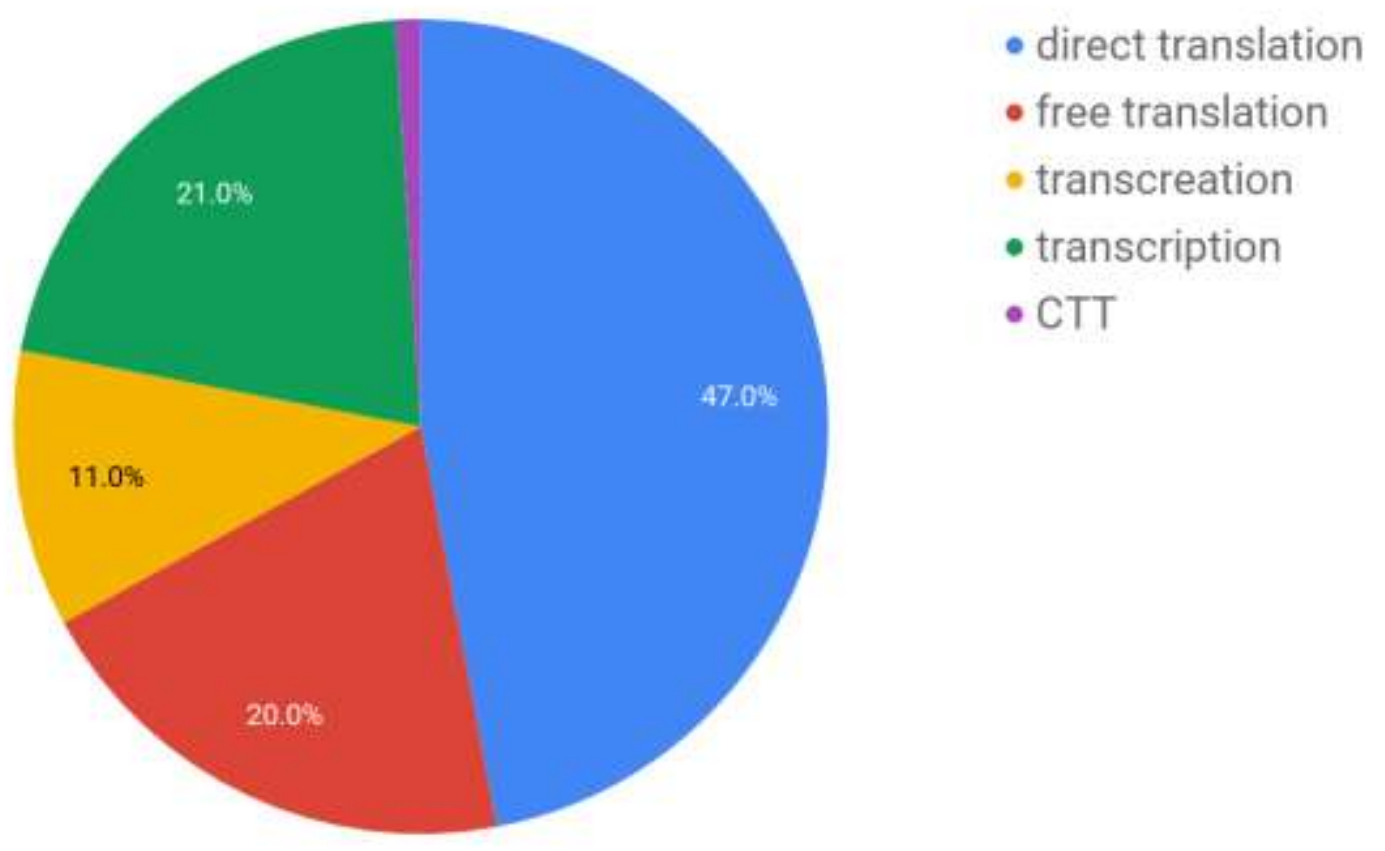

Graph 14 
Croatian translations, 2008-2017

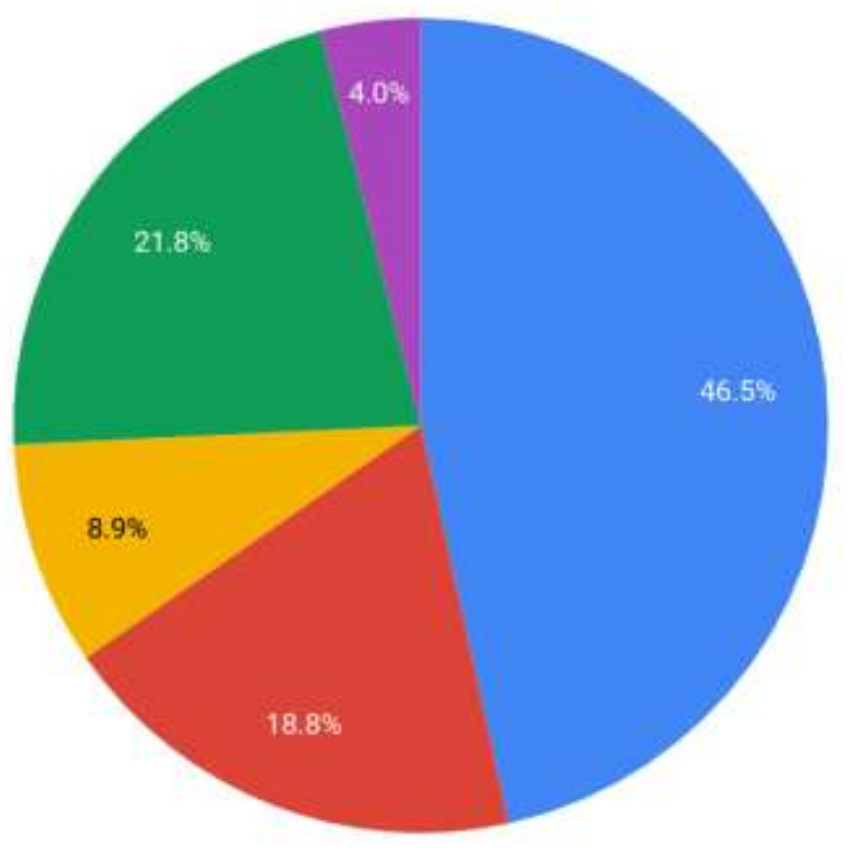

- direct translation

- free translation

- transcreation

- transcription

- CTT

\section{Graph 15}

German translations, 1928-1937

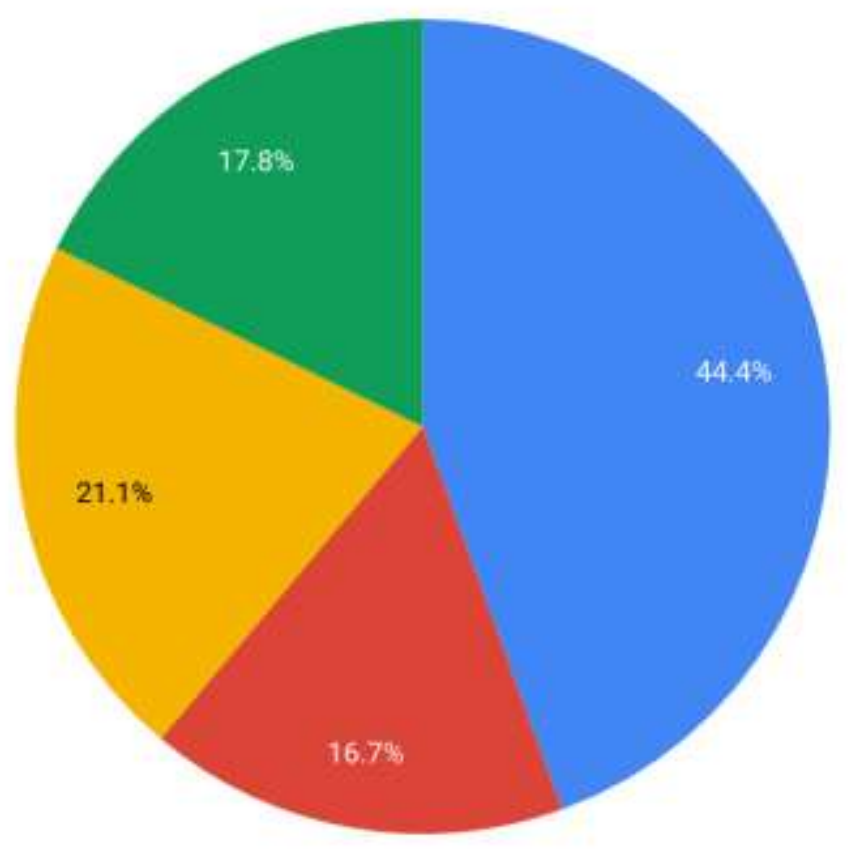

- direct translation

- free translation

- transcreation

- transcription

Graph 16 
German translations, 1938-1947

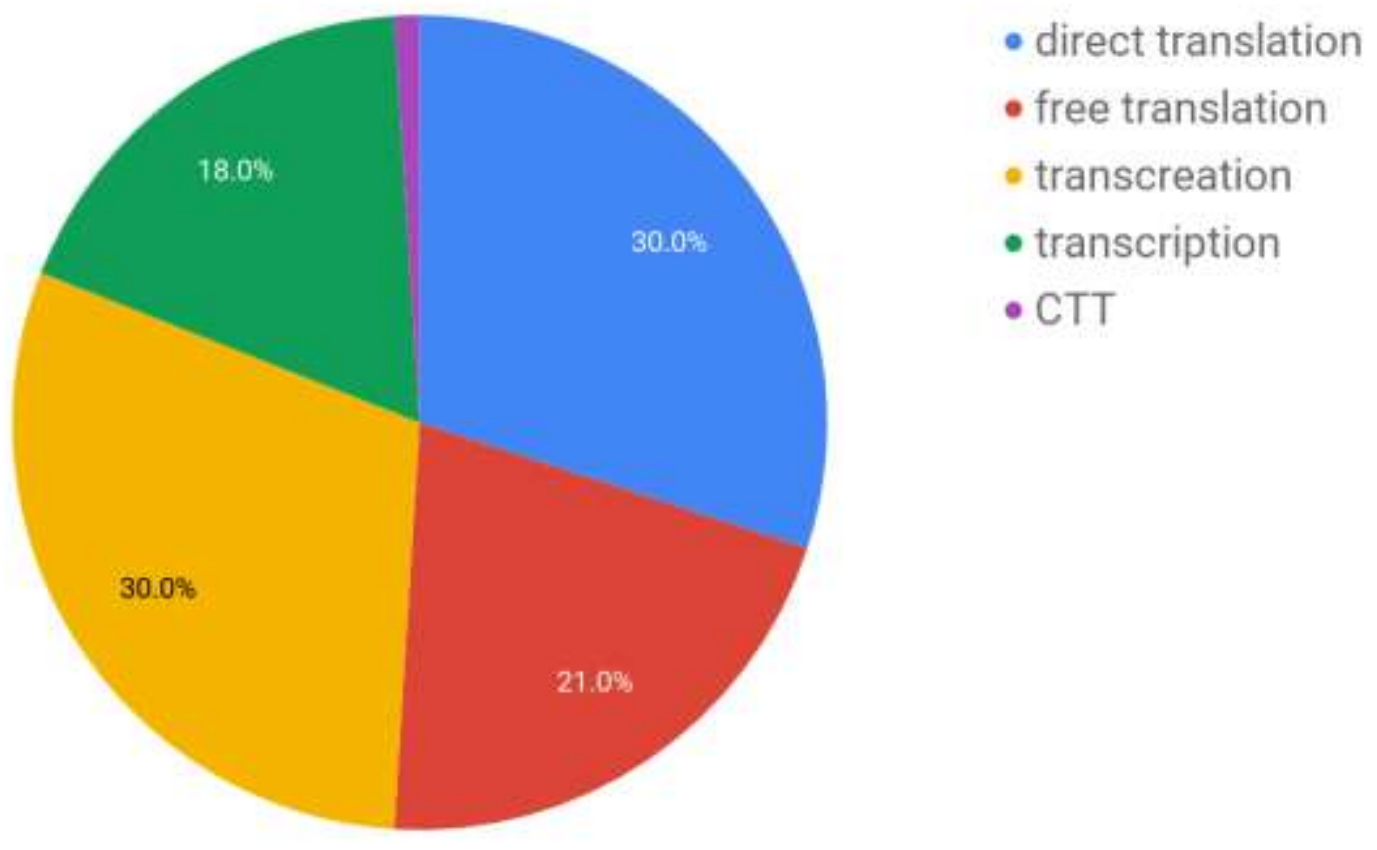

Graph 17

German translations, 1948-1957

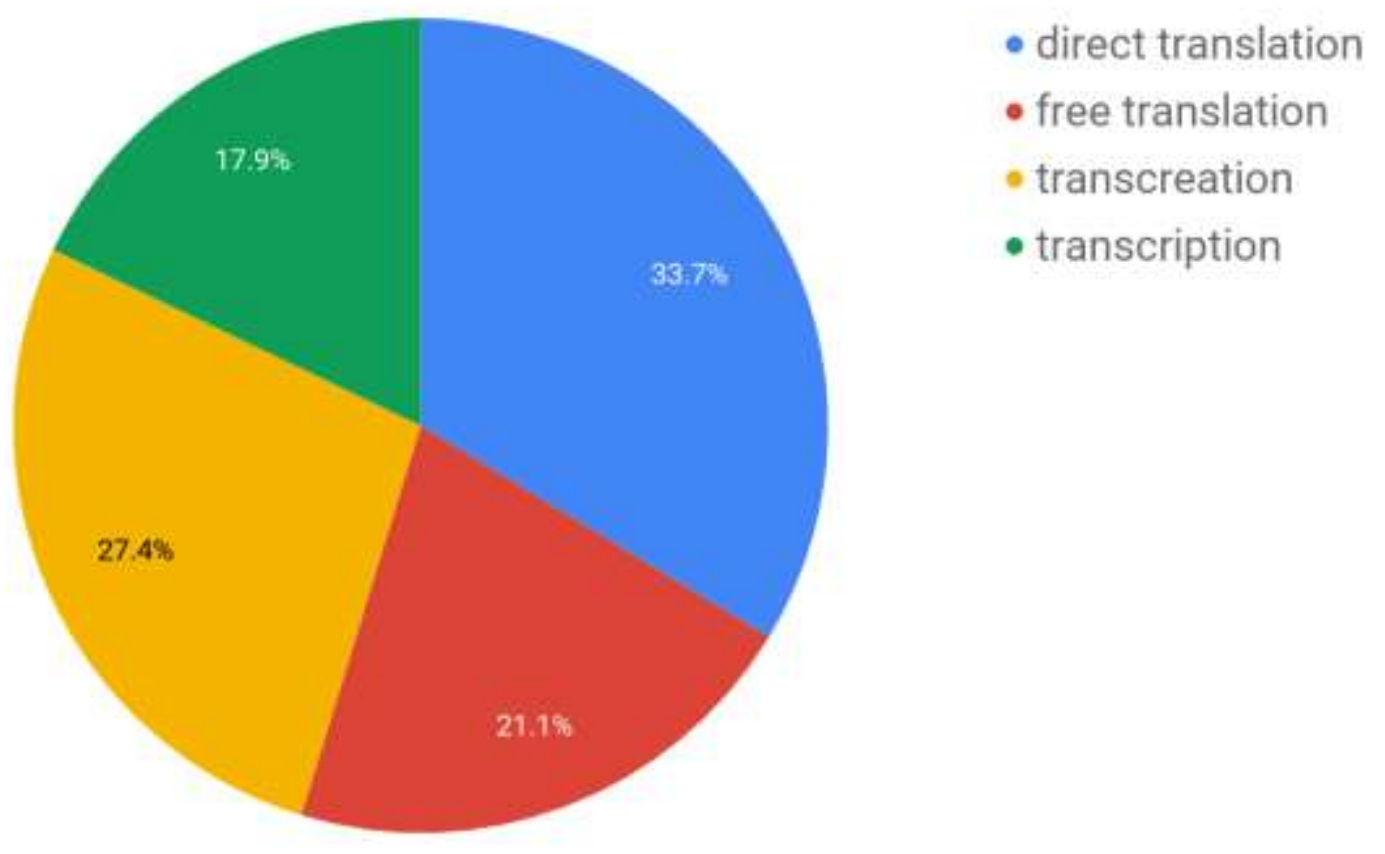

Graph 18 
German translations, 1958-1967

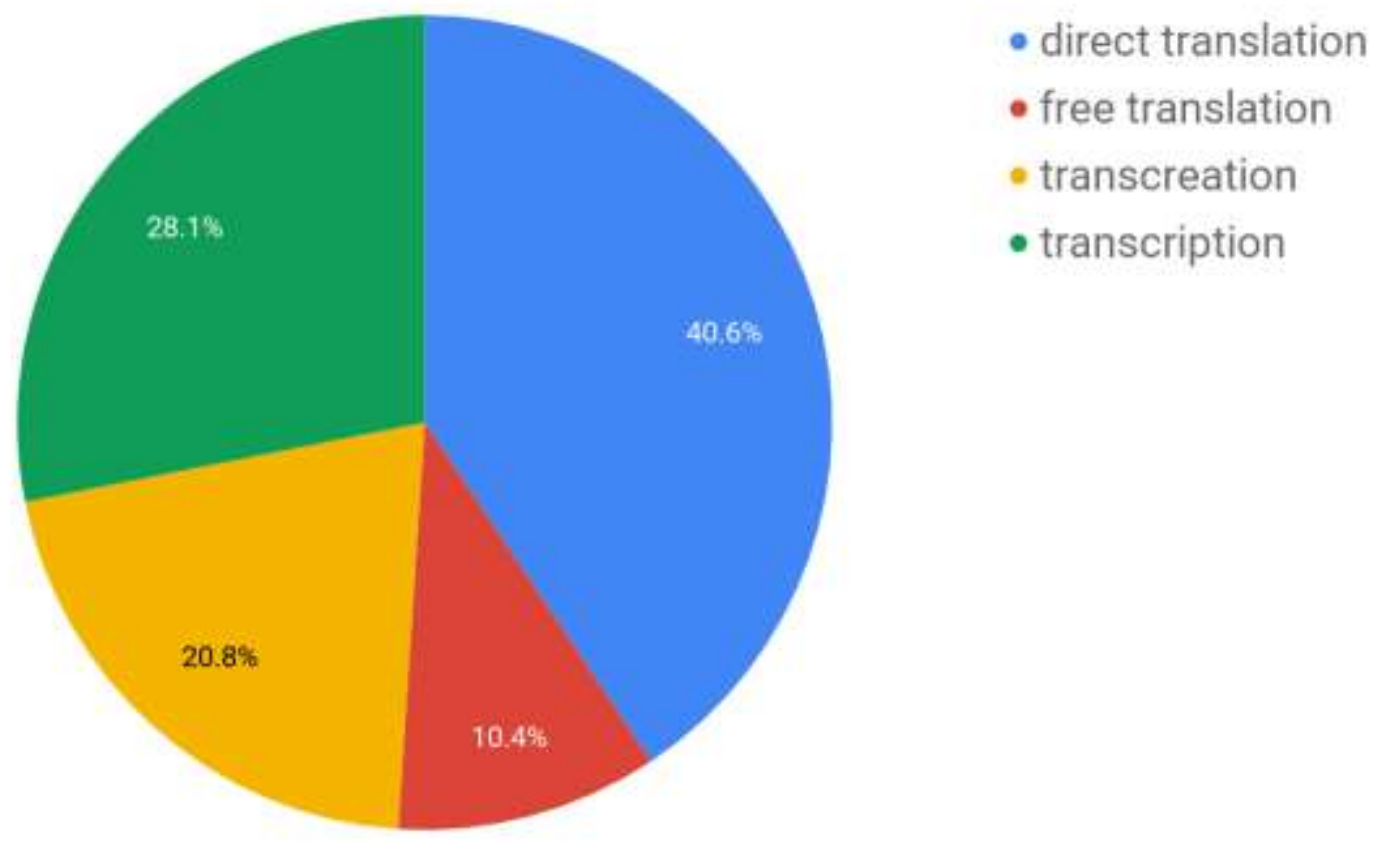

Graph 19

German translations, 1968-1977

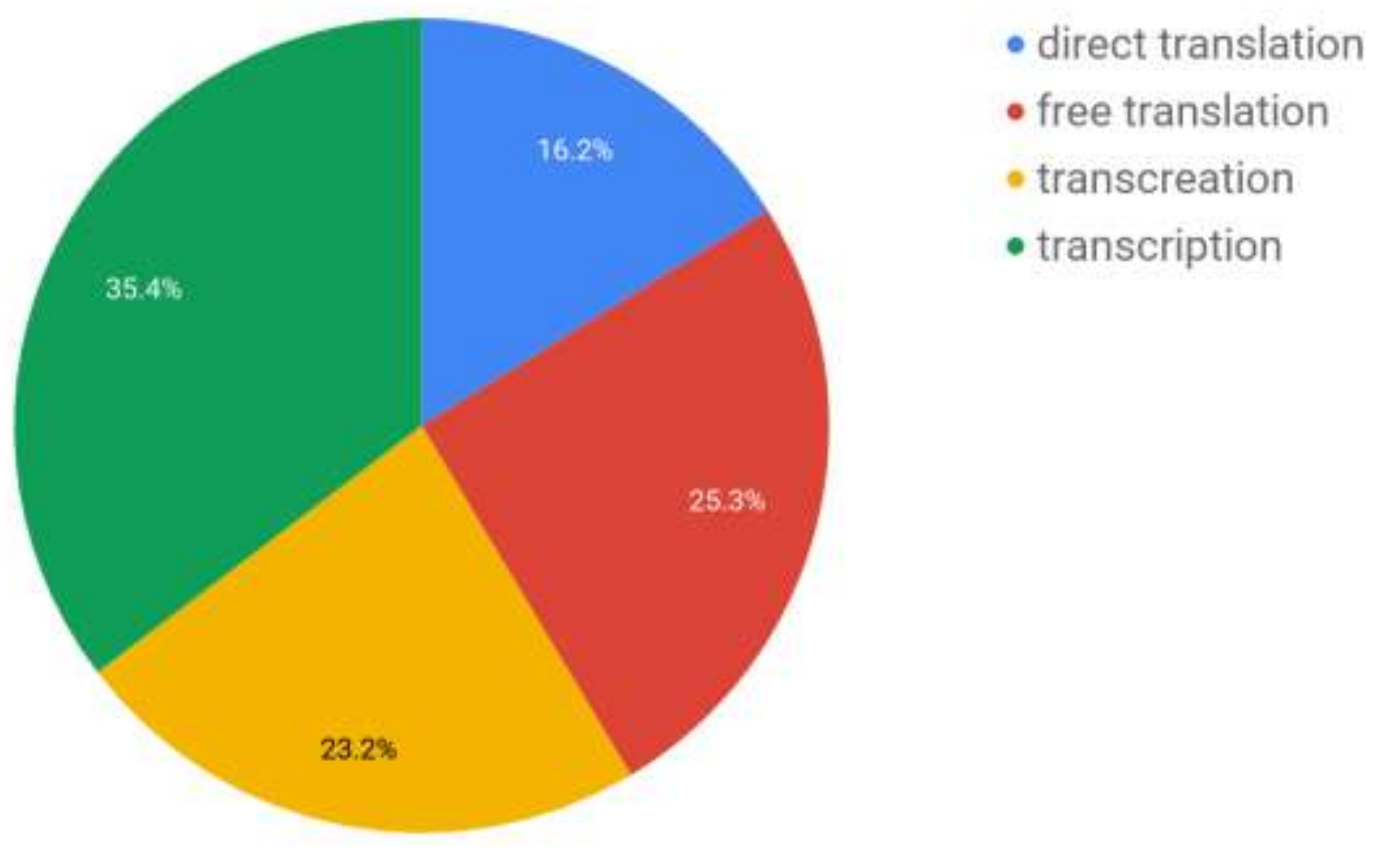

Graph 20 
German translations, 1978-1987

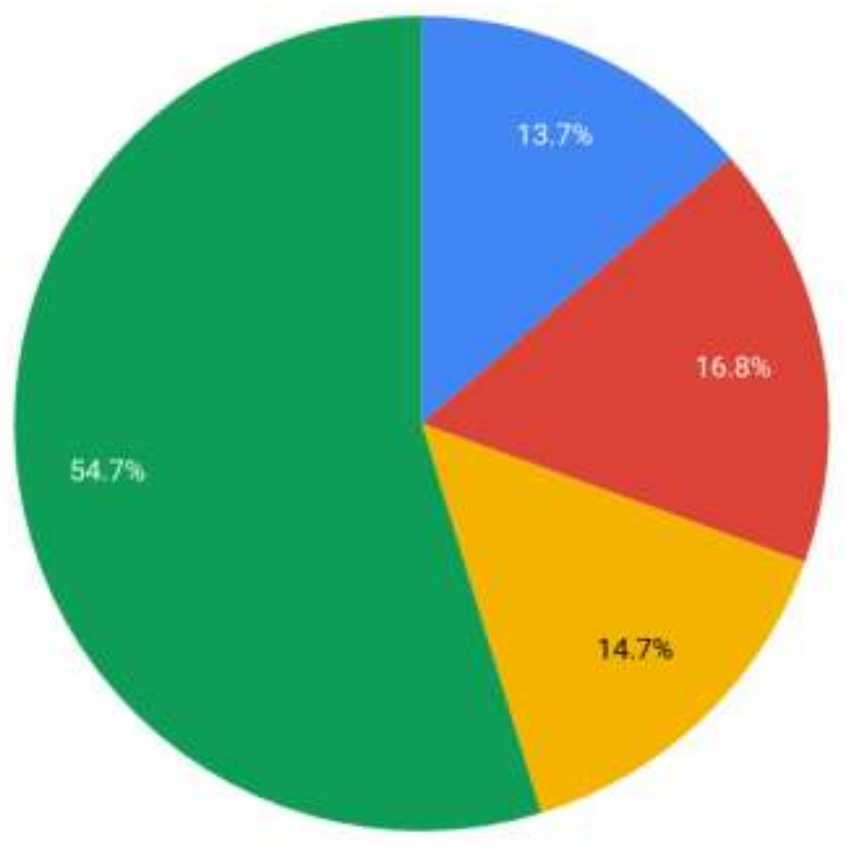

- direct translation

- free translation

- transcreation

- transcription

\section{Graph 21}

German translations, 1988-1997

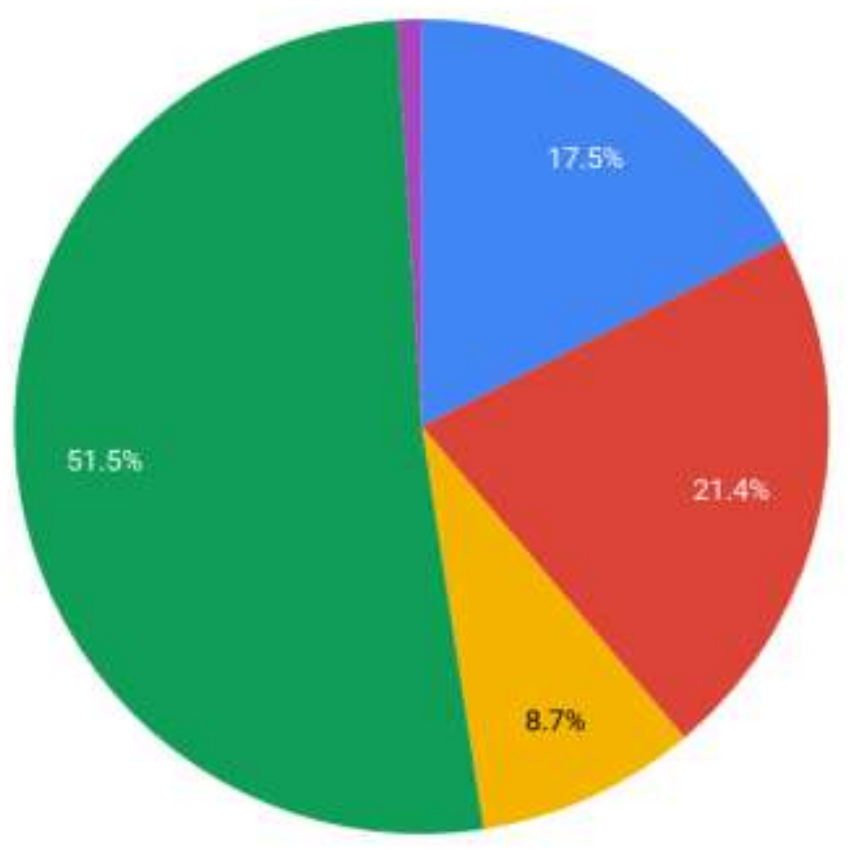

- direct translation

- free translation

- transcreation

- transcription

- CTT

\section{Graph 22}


German translations, 1998-2007

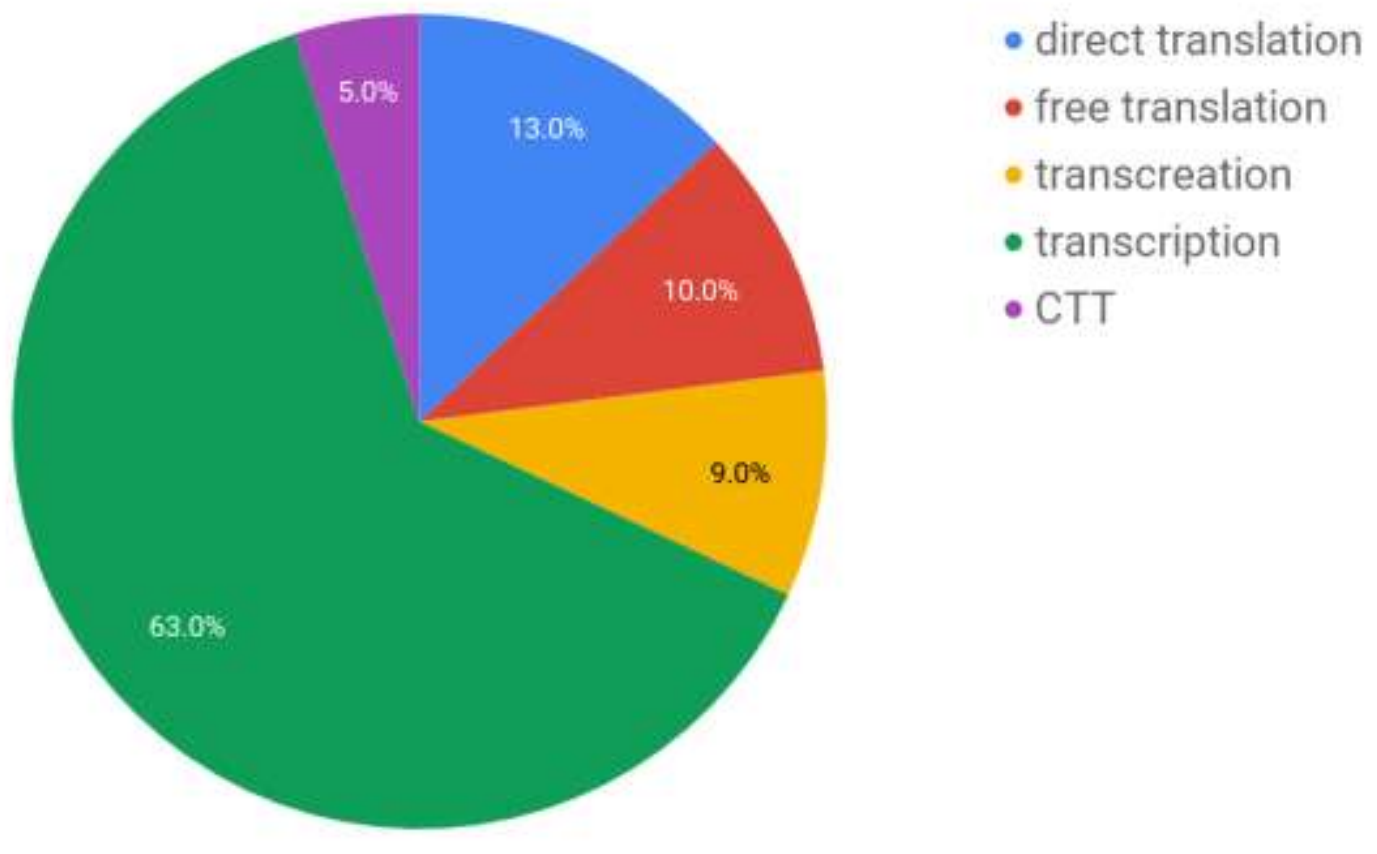

Graph 23

German translations, 2008-2017

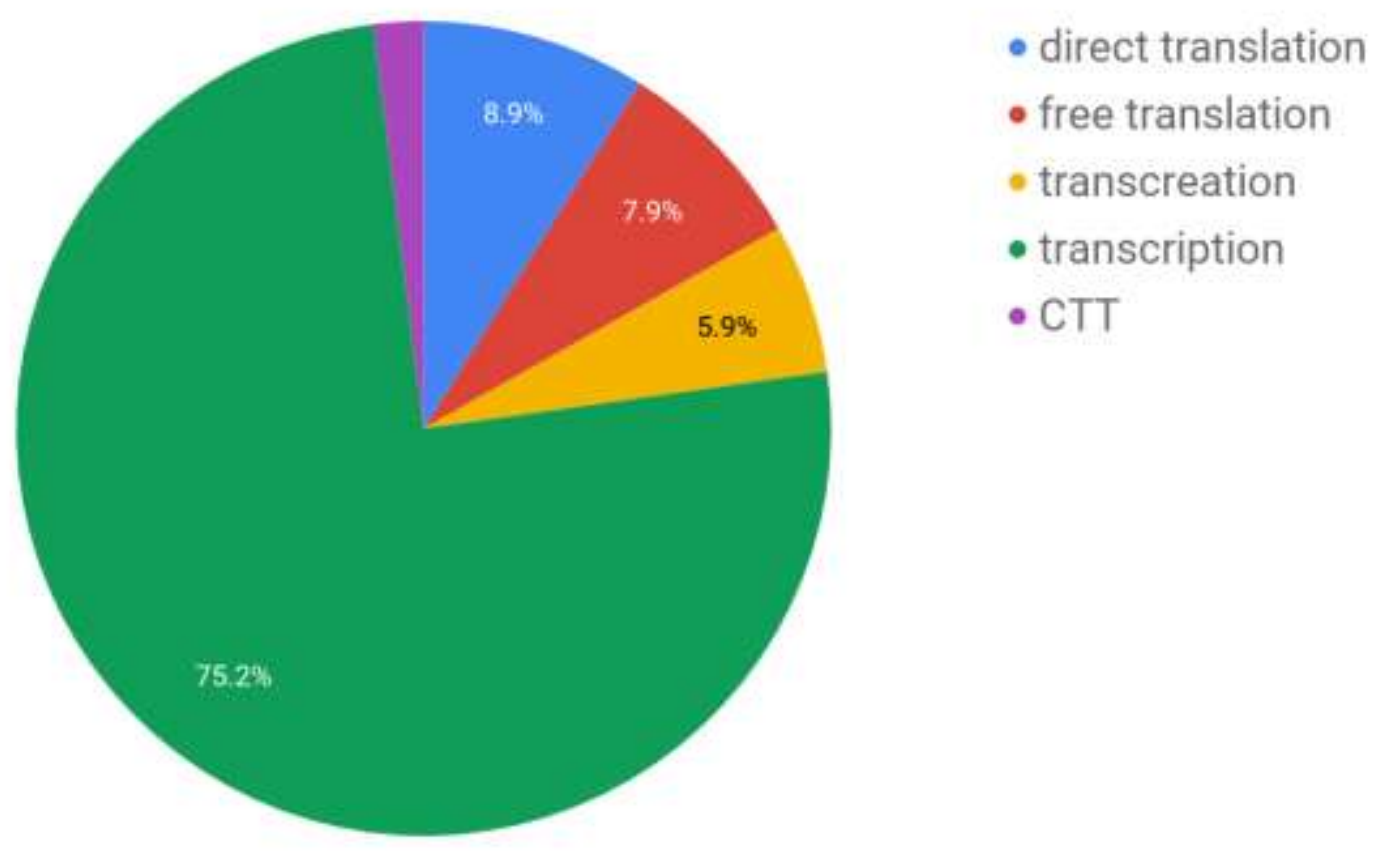

Graph 24 